UNIVERSIDADE DE SÃO PAULO

FACULDADE DE ECONOMIA, ADMINISTRAÇÃO E CONTABILIDADE DEPARTAMENTO DE CONTABILIDADE E ATUÁRIA PROGRAMA DE PÓS-GRADUAÇÃO EM CONTROLADORIA E CONTABILIDADE

\title{
A RELAÇÃO ENTRE A ADOÇÃO DE PRÁTICAS RECOMENDADAS DE GOVERNANÇA CORPORATIVA E O NÍVEL DE EVIDENCIAÇÃO
}

Sarah Chinarelli Teixeira

Orientador: Prof. Dr. Alexandre Di Miceli da Silveira

SÃo PAULO 
Prof. Dr. João Grandino Rodas Reitor da Universidade de São Paulo

Prof. Dr. Carlos Roberto Azzoni

Diretor da Faculdade de Economia, Administração e Contabilidade

Prof. Dr. Fábio Frezatti

Chefe do Departamento de Contabilidade e Atuária

Prof. Dr. Edgard Bruno Cornachione Junior Coordenador do Programa de Pós-Graduação em Ciências Contábeis 


\section{A RELAÇÃO ENTRE A ADOÇÃO DE PRÁTICAS RECOMENDADAS DE GOVERNANÇA CORPORATIVA E O NÍVEL DE EVIDENCIAÇÃO}

Dissertação apresentada ao Departamento de Contabilidade e Atuária da Faculdade de Economia, Administração e Contabilidade da Universidade de São Paulo como requisito para a obtenção do título de Mestre em Ciências Contábeis.

Orientador: Prof. Dr. Alexandre Di Miceli da Silveira

\section{SÃO PAULO}




\section{FICHA CATALOGRÁFICA}

Elaborada pela Seção de Processamento Técnico do SBD/FEA/USP

Teixeira, Sarah Chinarelli

A relação entre a adoção de práticas recomendadas de governança corporativa e o nível de evidenciação / Sarah Chinarelli Teixeira. - São Paulo, 2010.

$113 \mathrm{p}$.

Dissertação (Mestrado) - Universidade de São Paulo, 2010.

Orientador : Alexandre Di Miceli da Silveira.

1. Governança corporativa 2. Conselho de administração I. Universidade de São Paulo. Faculdade de Economia, Administração e Contabilidade II. Título.

$\mathrm{CDD}-658.4$ 


\section{AGRADECIMENTOS}

A concretização e desenvolvimento deste trabalho dependeram de muito esforço pessoal e em momentos difíceis e de alegria fui apoiada por familiares e amigos. Pela força, pelo suporte, pelas atitudes, pelos sonhos compartilhados, pelos conselhos, pela paciência, pelo carinho, pelos pensamentos positivos pelo afeto e por tudo mais, que não é possível colocar em palavras, agradeço e reconheço o apoio de todos e cada um que esteve e está presente na minha vida.

Agradeço a Deus, por me proporcionar a oportunidade de desenvolver o meu talento. Aos meus pais pela educação e por serem exemplos de vida no qual me apoio para seguir minha jornada e pela dedicação em todos os momentos, aos meus irmãos pelo incentivo e ajuda indispensável, a minha família que sempre esteve presente em minhas decisões e a todos que sempre estiveram dispostos a me ouvir e aconselhar. Agradeço aos meus avós que sempre estão presentes com palavras de carinho e incentivo e pelo exemplo de tenacidade e dignidade.

Meus agradecimentos ao Professor Doutor Alexandre di Miceli da Silveira, pela durante o processo de definição e orientação desta pesquisa, pela contribuição ao meu crescimento científico e intelectual dispensados nesses anos. Agradeço também aos professores e funcionários da FEA, que me proporcionaram novos conhecimentos. Minha gratidão também à Sandra Guerra que me apoiou durante o processo de elaboração desta dissertação e pelos ensinamentos e oportunidades que sempre me oferece.

Enfim, sou sinceramente grata aos meus antigos e novos amigos, que estão sempre presentes partilhando momentos felizes ou infortúnios, torcendo por mim em cada desafio e comemorando comigo cada desafio conquistado. Aos amigos que leram e revisaram este trabalho, pela paciência e carinho.

A realização de grandes conquistas é a fusão de atitudes, sonhos, planejamento e confiança. 
"Sucesso significa fazer o melhor que pudermos com aquilo que temos. Sucesso está em fazer, não em obter - está na tentativa, não no triunfo."

Wynn Davis 


\section{RESUMO}

O Conselho de Administração (CA) é foco de diversas pesquisas por ser considerado o principal mecanismo de governança corporativa. Inserido na linha de pesquisa que investiga o impacto da estrutura do CA sobre as decisões corporativas, esta pesquisa tem o intuito de verificar a relação entre o alinhamento às práticas recomendadas de governança relativas ao CA e o nível de evidenciação das empresas. Especificamente, avalia-se a relação de complementaridade ou substituição entre as práticas de governança e o nível de evidenciação. Adicionalmente, investiga-se a relação entre a presença do profissional da área contábil nos conselhos e o nível de evidenciação das empresas. Optou-se pela elaboração de índices para mensurar o alinhamento às práticas de governança. $O$ índice construído é composto por subíndices referentes à independência, disponibilidade de tempo, diversidade e comitês. Para a variável dependente, foi elaborado um índice de evidenciação com base na divulgação de políticas sobre gerenciamento de risco, gastos com auditoria, operações com partes relacionadas, código de ética e remuneração dos administradores. Foram realizadas análises exploratórias por meio de diferenças de médias entre determinados grupos de empresas, e análise de dados em painel a fim de verificar a consistência das relações entre o alinhamento às práticas de governança e o nível de evidenciação. Os resultados exploratórios evidenciam que tanto a média do índice de alinhamento às práticas de governança do CA quanto o índice de evidenciação ficaram abaixo da metade da pontuação máxima, 16 e 6 pontos, respectivamente. Constata-se que muitas recomendações em relação à independência, disponibilidade de tempo, diversidade e comitês ainda não foram adotadas pelas empresas, havendo ainda muito a ser aprimorado. Em relação à participação do profissional da área contábil, destaca-se que empresas com conselheiros ou membros externos com formação em contabilidade na composição do Comitê de Auditoria apresentam média estatisticamente superior em relação ao índice de evidenciação se comparada às empresas que não têm profissionais com essa formação na composição deste Comitê. Os resultados da análise de dados em painel não confirmam a hipótese desta pesquisa em relação à complementaridade entre a adoção de práticas recomendadas de governança corporativa e o nível de evidenciação. Porém confirmam a complementaridade entre o nível de evidenciação e as variáveis relacionadas à negociação no Novo Mercado e na Bolsa de Nova Iorque (empresas com emissão de ADRs), provavelmente este fato pode sugerir o esforço dos administradores em evidenciar informações devido ao fortalecimento do papel de monitoramento dos conselhos das empresas com estas características. Os progressos nas melhorias das práticas de governança corporativa no Brasil dependem de maior ação dos agentes de mercado e as evidências desta pesquisa indicam alguns pontos para melhoria e aprofundamento de pesquisas acadêmicas tanto na adoção de práticas de governança quanto no nível de transparência de informações.

Palavras-chave: nível de evidenciação, governança corporativa, diversidade, conselho de administração, índice de alinhamento às melhores práticas. 


\begin{abstract}
The Board of Directors (BoD) is the focus of several researches as it is considered the main corporate governance mechanism. Following the research line that investigates the impact of BoD structure on corporate decisions, this research aims to investigate the relationship between the alignment of recommended governance practices related to the $\mathrm{BoD}$ and the disclosure level of companies. Specifically, it evaluates the complementary or substitute relationship between governance practices and disclosure level. Additionally, it investigates the relationship between the presence of accounting professional in the $\mathrm{BoD}$ and the disclosure level of companies. An index has been elaborated to measure the alignment to corporate governance practices. The index has been built comprising sub indexes relating to independence, time availability, diversity and committees. For the dependent variable, a disclosure index has been elaborated based on disclosure of policies on risk management, audit expenditures, related party transactions, ethics code and administrators' remuneration. Exploratory analyses were performed by differences between average of certain companies groups and panel data analysis to verify the consistency of the relationship between governance practices alignment and disclosure level. The exploratory results presented that both means of alignment to governance practices of BoD index and disclosure index were below half the maximum score, 16 and 6 points respectively. It appears that many recommendations in relation to independence, time availability, diversity and committees have not yet been adopted by companies and there is still much to be improved. Regarding the accounting professionals participation in $\mathrm{BoD}$, the relevant results presented that companies that have directors or external advisors with accounting background in the composition of the Audit Committee have statistically higher average of disclosure index compared to companies that do not have accounting professionals in the composition of this Committee. The panel data analysis results haven't confirmed the research hypothesis that there is a complementary relationship between the adoption of recommended governance practices and disclosure level. However confirm the complementarity between the level of disclosure and the variables related to trading on Novo Mercado and New York Stock Exchange (companies issuing ADRs), probably this may suggest this relation follows the administrators' efforts to disclose information due to the strengthening of boards monitoring role. Progress in the improvement of corporate governance practices in Brazil depends on greater action of market agents, the evidences of this research indicate some points for improvement and further academic research development in both adoption of governance practices and on transparency information level.
\end{abstract}

Keywords: disclosure level, corporate governance, diversity, board of directors, index alignment to best practices. 


\section{SUMÁRIO}

LISTA DE TABELAS

1 INTRODUÇÃO

1.1 QUESTÃo DE PESQUISA

1.2 OBJETIVO

6

1.3 HiPÓTESES

7

1.4 JUSTIFICATIVAS

8

1.5 CONTRIBUIÇÕES

1.6 DELIMITAÇÕES

10

1.7 ESTRUTURA Do Trabalho

11

2 PLATAFORMA TEÓRICA

2.1 EFETIVIDADE DO CONSELHO

2.2 PRÁtiCAS RECOMENDADAS DE GOVERNANÇA CORPORATIVA

2.2.1 INDEPENDÊNCIA

2.2.2 SEPARAÇÃO DOS PAPÉIS DE PRESIDENTE EXECUTIVO E PRESIDENTE DO CONSELHO 24

2.2.3 DIVERSIDADE

2.2.4 DISPONIBILIDADE DE TEMPO

2.2.5 COMITÊS

2.3 NíVEL DE EVIDENCIAÇÃo

$\underline{3}$ PROCEDER METODOLÓGICO

3.1 HiPÓTESES

3.2 MODELO

3.3 TRATAMENTO ESTATíSTICO

3.4 DEFINIÇÃO TEÓRICA E OPERACIONAL DAS VARIÁVEIS 46

3.5 População, Amostra e Período

3.6 FONTES DE COLETA DE DADOS

$\begin{array}{lll}3.7 & \text { LIMITAÇÕES } & 53\end{array}$

4 ANÁLISE DE RESULTADOS

4.1 AMOSTRA PESQUISADA

$\begin{array}{lll}4.2 & \text { ESTATÍSTICAS DESCRITIVAS } & 57\end{array}$

4.3 ANÁLISE EXPLORATÓRIA

4.3.1 TESTES DE DIFERENÇA DE MÉDIAS - ÍNDICE DE ALINHAMENTO DE GOVERNANÇA CORPORATIVA

4.3.2 TESTES DE DIFERENÇA DE MÉDIAS - SUBÍNDICE DE INDEPENDÊNCIA

4.3.3 TESTES DE DIFERENÇA DE MÉDIAS - SUBÍNDICE DE DISPONIBILIDADE DE TEMPO 72

4.3.4 TESTES DE DIFERENÇA DE MÉdIAS - SUBÍNDICE DE DIVERSIDADE

4.3.5 TESTES DE DIFERENÇA DE MÉDIAS - SUBÍNDICE DE COMITÊS

4.3.6 TESTES DE DIFERENÇA DE MÉDIAS - ÍNDICE DE EVIDENCIAÇÃo 76 
4.3.7 TESTES DE DIFERENÇA DE MÉDIAS - ÍNDICE DE EVIDENCIAÇÃo E ÍNDICE DE AlinhaMENTO DE PRÁTICAS DE GOVERNANÇA CORPORATIVA

4.3.8 ASSOCIAÇÕES ENTRE NÍVEL DE EVIDENCIAÇÃO E VARIÁVEIS EXPLICATIVAS

80

4.4 RESULTADOS DA ANÁLISE EM PAINEL

83

4.5 RESUMO DOS RESULTADOS

$\underline{5}$ CONSIDERACÕES FINAIS 


\section{LISTA DE TABELAS}

Tabela 1- Empresas por tipo de estrutura de controle ...................................................58

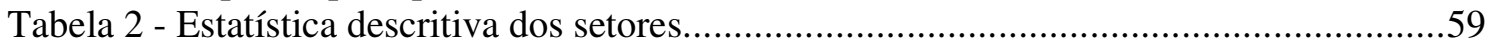

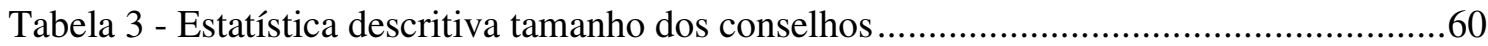

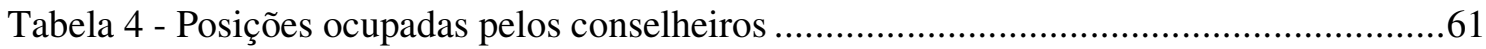

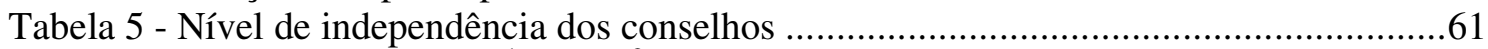

Tabela 6 - Separação cargos $\mathrm{PE}^{1}$ e $\mathrm{PCA}^{2}$......................................................................63

Tabela 7 - Disponibilidade de tempo - Conselhos que têm conselheiros com participação em

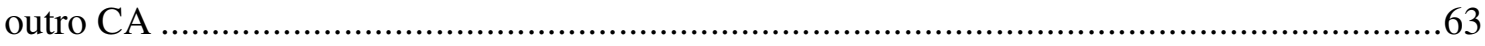

Tabela 8 - Diversidade de formação dos conselheiros - 2007 ...........................................64

Tabela 9 - Diversidade de formação dos conselheiros - 2008 ........................................64

Tabela 10 - Diversidade de qualificação dos conselheiros ..............................................65

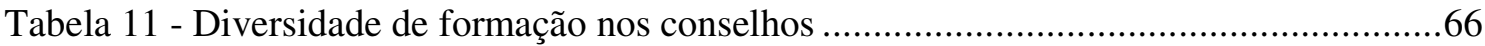

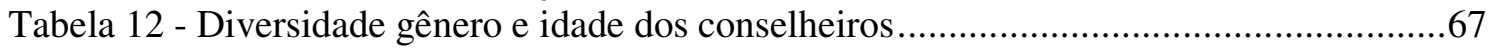

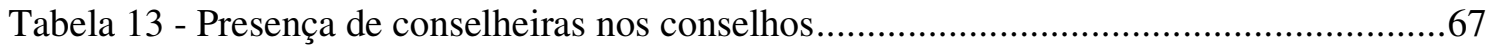

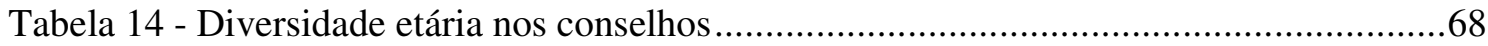

Tabela 15 - Teste de diferença de média - Nível de Alinhamento de GC .............................70

Tabela 16 - Teste de diferença de média - Nível de Independência ....................................72

Tabela 17 - Teste de diferença de média - Nível de Disponibilidade de Tempo.....................73

Tabela 18 - Teste de diferença de média - Nível de Diversidade .........................................74

Tabela 19 - Teste de diferença de média - Comitês ...........................................................76

Tabela 20 - Teste de diferença de média - Nível de Evidenciação .......................................77

Tabela 21 - Teste de diferença de média - Presença de Conselheiros com formação em

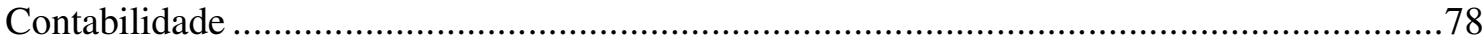

Tabela 22 - Teste de diferença de média - Nível de Evidenciação e Alinhamento de GC.......79

Tabela 23 - Resultados das correlações entre nível de evidenciação, alinhamento às práticas

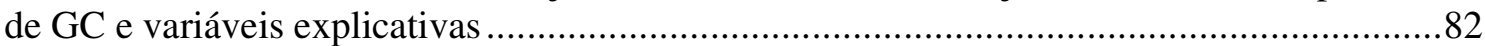

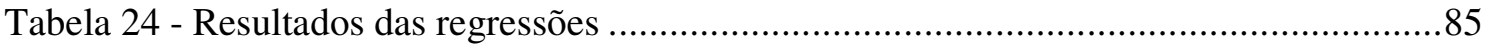




\section{INTRODUÇÃO}

\subsection{Questão de pesquisa}

O Conselho de Administração (CA) é considerado o principal mecanismo interno de governança corporativa. De acordo com a teoria de agência, a principal função do conselho é monitorar as ações dos gestores, no intuito de assegurar que seus interesses estejam alinhados aos dos acionistas (GILLAN, 2006). Outras vertentes de pesquisa argumentam que, além de monitorar os gestores, o conselho tem como função gerar valor para a companhia na tomada de decisões estratégicas (HILMER; TRICKER, 1994; CLARKE, 2007).

A linha de pesquisa que investiga o relacionamento entre a estrutura do CA e seu impacto nas decisões corporativas possui poucos estudos que abordam a relação entre as práticas de governança e o nível de evidenciação das informações. Além da análise da estrutura dos conselhos (abordando temas como tamanho do órgão e separação de cargos entre presidente do conselho e diretor presidente), há certo consenso na literatura de que o progresso nessa área depende fundamentalmente de um melhor entendimento acerca da diversidade e da dinâmica interna dos conselhos de administração (HERMALIN; WEISBACH, 2001; PETTIGREW, 1992). Com o intuito de explorar esta dinâmica, alguns atributos fundamentais dos conselheiros devem ser levados em consideração na composição dos conselhos, tais como independência, qualificação, disponibilidade de tempo e incentivos adequados (TIROLE, 2006).

Pettigrew e McNulty (1998) argumentam que o envolvimento e a influência do CA nas empresas são medidos não apenas pelas condições externas e características estruturais do conselho, mas também pelos processos, motivações e habilidades individuais dos conselheiros que atuam como membros de um grupo funcional. Sob a suposição implícita da teoria da informação e da teoria de agência, Ho e Wong (2001), sugerem, por sua vez, que o aperfeiçoamento no monitoramento do conselho de administração poderia influenciar o nível de evidenciação voluntária das empresas. Ao desempenhar efetivamente a função de 
monitoramento, as empresas teriam incentivos para serem mais transparentes, de forma a atender as demandas de informações dos investidores e demais stakeholders ${ }^{l}$.

Outros estudos internacionais seguem essa linha de pesquisa, investigando a relação entre os mecanismos de governança e o nível de evidenciação das empresas (ENG; MAK, 2003; LANZANA, 2004; BEEKES; BROWN, 2006; CLUBB, 2006; BEEKES et al., 2007; DONNELLY; MULCAHY, 2008). Haniffa e Cooke (2000) argumentam que o CA é o órgão responsável por determinar o nível de transparência da empresa. Logo, a análise do grau de alinhamento do CA às práticas de governança relativas à independência, disponibilidade de tempo, diversidade e comitês, poderia ser um indicador para averiguar a associação com fatores relacionados ao nível de evidenciação de informações empresariais.

O processo de evidenciação das informações junto ao mercado, investidores e stakeholders geraria redução da assimetria informacional entre gestores e investidores (JENSEN; MECKLING, 1976). A divulgação de informações tempestivas e consistentes para o mercado poderia ser considerada como uma maneira de equalizar os direitos entre todos os acionistas; assim os gestores que divulgassem informações ao mercado de capitais obteriam mais credibilidade.

Nesse contexto, torna-se relevante investigar a relação entre o alinhamento do CA às práticas de governança e o nível de evidenciação das empresas. Especificamente, esta pesquisa visa responder a seguinte questão: A adoção de práticas recomendadas de governança corporativa relativas ao CA apresenta relação significativa com o nível de evidenciação das companhias brasileiras de capital aberto?

\subsection{Objetivo}

Como objetivo principal, esta pesquisa busca verificar a relação entre o alinhamento às práticas recomendadas de governança relacionadas ao CA e o nível de evidenciação das empresas. Para alcançar este objetivo são construídos dois índices com o intuito de averiguar relações entre: o índice de alinhamento do CA às práticas de governança e o índice de evidenciação.

\footnotetext{
${ }^{1}$ Qualquer pessoa, entidade ou sistema que afeta ou é afetada (o) pelas atividades de uma organização. Partes interessadas. (IBGC, 2009).
} 
O índice de alinhamento às práticas de governança é composto por quatro subíndices: independência, disponibilidade de tempo, diversidade e comitês. Já o índice de evidenciação tem como base a divulgação de informações referentes às políticas sobre partes relacionadas, ética, remuneração do conselho e da diretoria executiva, gerenciamento de riscos e gastos com auditoria das empresas.

Como objetivo específico adicional, avalia-se também a atuação do profissional com formação na área contábil, investigando-se a associação entre o nível de evidenciação e a participação desses profissionais nos conselhos e comitês de Auditoria. De acordo com DeFond et al. (2005), a expertise em contabilidade pode ser importante para o conselho e para o comitê de auditoria, já que esses órgãos são responsáveis por tarefas que requerem um nível relativamente elevado de sofisticação do conhecimento contábil.

\subsection{Hipóteses}

De acordo com a literatura (LEVRAU; VAN DEN BERGHE, 2007; JOHN; SENBET, 1998; VAN DEN BERGHE; LEVRAU, 2004; NICHOLSON; KIEL, 2004), a efetividade do funcionamento do conselho pode ser impactada não somente pela composição per se, mas também, por outros atributos relacionados às características individuais dos conselheiros, como qualificação, formação, disponibilidade de tempo e motivação. Considera-se que os conselhos alinhados às recomendações de governança relativas à composição e aos atributos individuais dos conselheiros constituem um indicador de alinhamento do CA às boas práticas de governança. Logo, a hipótese a ser testada é da existência de relação entre o alinhamento às práticas de governança do CA e o nível de evidenciação.

Partindo da hipótese que a adoção de práticas de governança poderia afetar o nível de evidenciação das empresas, esta relação poderia, segundo a literatura, ser complementar ou substituta. No caso de ser complementar, sugere-se que um maior nível de evidenciação seria esperado quando da adoção de mecanismos internos de controle, já que, neste caso, haveria um "pacote de monitoramento" para a empresa reduzir assimetria informacional e comportamentos oportunistas. Assim, em um ambiente de intenso monitoramento, seria esperado que os administradores não tivessem incentivos em deter informações para benefício próprio, o que levaria a um aumento da evidenciação (JENSEN; MECKLING, 1976). Boas 
práticas de governança corporativa relativas aos conselhos poderiam contribuir para o aumento da transparência e da evidenciação (THE RELATIONSHIP, 2002; BEEKES; BROWN, 2006; BEEKES et al., 2007), a não ser que a empresa já esteja em patamar ótimo de evidenciação.

Do ponto de vista da relação de substituição, as empresas com maior nível de evidenciação apresentariam pior estrutura de governança. Neste caso, em linha com o argumento de Lanzana (2004), o menor controle e monitoramento interno seriam compensados pela transparência na evidenciação de forma a atrair investidores externos.

\subsection{Justificativas}

A estrutura do conselho de administração é um dos principais assuntos nas discussões sobre governança corporativa, sendo a composição e a independência do conselho questões de ampla relevância. No que concerne às melhores práticas de governança, o mote da independência dos conselheiros é tido como essencial. Bhagat e Black (2001) argumentam que, dentre as tarefas do conselho, a principal é o monitoramento da administração e que somente membros independentes podem ser monitores efetivos. Nesse sentido, acredita-se que a independência leve os conselheiros a agirem no interesse do acionista buscando aperfeiçoamentos substanciais no ambiente de governança das empresas (DEFOND et al., 2005).

Segundo Tirole (2006), para que os conselheiros possam atuar como monitores efetivos são necessários alguns atributos que aperfeiçoem as atividades desenvolvidas no conselho de administração, tais como qualificação, conhecimento e disponibilidade de tempo para envolvimento com os assuntos essenciais do conselho. Diante do exposto, abordam-se nesta pesquisa recomendações relativas à diversidade, disponibilidade de tempo, estruturas de comitês e independência como indicadores de alinhamento às práticas de governança do CA.

A cultura empresarial apresenta condições favoráveis à prestação de contas e à prática da divulgação de informações mais amplas quando há alinhamento do CA às práticas recomendadas de governança corporativa. Não obstante, a evidenciação é um dos pilares que baseiam o sistema de governança. Dentre os pilares estão: equidade (fairness); transparência 
(disclosure); prestação de contas (accountability); e obediência e cumprimento das leis (compliance), de acordo com o IBGC (2009).

Alguns trabalhos internacionais (DONNELLY; MULCAHY, 2008; CLUBB, 2006; BEECKS; BROWN, 2006) investigaram a associação entre a estrutura do conselho e o nível de evidenciação. Na esfera nacional, porém, essas investigações envolvendo o nível de evidenciação foram exploratórias (LANZANA, 2004; PONTE et al., 2006; GALLON et al., 2008) ou foram realizadas tangencialmente em estudos que abordaram a relação entre índices de governança e o valor das empresas (LEAL; CARVALHAL-DA-SILVA, 2007). Nas pesquisas de âmbito nacional pouco se explora a relação direta entre o alinhamento do CA às melhores práticas de governança e o nível de evidenciação.

Dentre as justificativas para realização da pesquisa está o fato de contribuir para a investigação da dinâmica do CA e indiretamente a promoção de melhores práticas de governança e divulgação de informações, fazendo com que se desenvolva o círculo virtuoso citado por Silveira (2006). Neste círculo, a evolução do mercado caminha lado a lado com o aumento dos mecanismos de governança e a consequente elevação da proteção aos acionistas, gerando confiança aos investidores. Não obstante os custos associados à instituição de mecanismo de governança, reduzem-se os custos para as empresa que se financiam nos mercados de capitais. Adicionalmente, os resultados podem ser de interesse dos reguladores engajados com a formulação e encorajamento da adoção de recomendações de governança com a finalidade de aprimorar as recomendações em relação à evidenciação, disponibilidade de tempo dos conselheiros, independência, diversidade e estrutura de comitês dos conselhos.

\subsection{Contribuições}

O presente trabalho apresenta três contribuições principais. Em primeiro lugar, trata-se de trabalho pioneiro no Brasil que avalia a relação entre as práticas recomendadas de governança relacionadas ao CA e o nível de evidenciação restrito às políticas das empresas com o intuito de verificar a relação de complementaridade ou substituição dos mecanismos.

Em segundo, ressalta-se a abrangência do índice de alinhamento às práticas de governança relativas aos conselhos, o qual engloba questões relacionadas à independência, 
disponibilidade de tempo, diversidade e comitês. Apresenta-se uma abordagem alternativa para analisar mais detalhadamente variáveis relativas à diversidade de formação, qualificação, gênero e idade dos conselheiros que compõem os conselhos, oferecendo um panorama sobre a diversificação na composição dos conselheiros, ainda não reportado no Brasil.

E, por fim, investiga-se a presença do profissional da área contábil nos conselhos a fim de averiguar a contribuição desse profissional para o aperfeiçoamento dos debates e diversidade na composição dos conselhos, além de explorar as associações entre a presença destes profissionais e o nível de evidenciação das empresas.

Um melhor entendimento do conselho de administração é necessário para a evolução das pesquisas e para promover a relevância da adoção de práticas de governança corporativa para o alinhamento de interesses. O entendimento da contribuição dos profissionais com qualificação peculiar na área contábil é essencial para o enriquecimento da dinâmica dos conselhos e do nível de evidenciação. Como implicação da compreensão e detalhamento das práticas recomendadas de governança relacionadas ao CA e ao nível de evidenciação das empresas, decorre-se possíveis sugestões para futuros aprimoramentos de políticas de governança e futuras pesquisas.

\subsection{Delimitações}

Este trabalho delimita-se a investigar práticas de governança relacionadas ao conselho de administração, não abrangendo outros mecanismos de governança, tais como mercado de aquisições hostis, remuneração dos administradores, sistemas de controles internos, mercado competitivo de trabalho, entre outros.

Em relação ao nível de evidenciação limitou-se a abordagem de evidenciação voluntária de políticas adotadas pelas empresas no que se relacionam à ética, partes relacionadas, remuneração, gerenciamento de riscos e gastos com auditoria. 


\subsection{Estrutura do Trabalho}

Este trabalho está organizado em 5 seções. Na Introdução encontram-se descritas a questão de pesquisa, objetivo, hipótese, justificativas, contribuições e delimitações. No capítulo 2, apresenta-se a revisão bibliográfica, com o objetivo de evidenciar diferentes trabalhos que abordaram práticas e recomendações de governança relativas à independência, disponibilidade de tempo, diversidade e comitês, assim como trabalhos envolvendo nível de evidenciação. O intuito foi de obter um melhor conhecimento das diversas variáveis e/ou indicadores seriam utilizados nas posteriores análises. A seção 3, descreve a metodologia da pesquisa, modelo, variáveis, amostra e período e limitações. No item 4, são apresentadas as análises descritivas, exploratórias, resultados das regressões e sumarização dos resultados obtidos. Por fim, na seção 5, apresenta-se às considerações finais do trabalho. 


\section{PLATAFORMA TEÓRICA}

Com os movimentos atuais do mercado de capitais torna-se cada vez mais relevante à evolução dos estudos relacionados à governança corporativa. Muitos são os trabalhos da $3^{\mathrm{a}}$ geração que verificaram os impactos de diversos mecanismos de governança no desempenho e valor das empresas (KLAPPER; LOVE, 2004; BEINER et al., 2004; DURNEV; KIM, 2005; BLACK et al., 2006; CARVALHAL-DA-SILVA; LEAL, 2005; SILVEIRA et al., 2003; SILVEIRA, 2006).

Uma abordagem emergente são trabalhos que envolvem as relações internas dos conselhos, avaliando os efeitos dos mecanismos de governança na dinâmica do conselho e na sua efetividade (LEVRAU; VAN DEN BERGHE, 2007; JOHN; SENBET, 1998; NICHOLSON; KIEL, 2004). Essa pesquisa segue essa linha com o intuito de investigar as relações entre a adoção de melhores práticas de governança relativas ao CA e o efeito no nível de evidenciação das empresas.

No que concerne esse assunto, a OCDE (2004) comenta que a estrutura de governança corporativa deve assegurar divulgação oportuna e precisa de todos os fatos relevantes referentes à empresa. Verifica-se, assim, que evidenciação e transparência consubstanciam-se em um dos principais pilares da governança corporativa, de grande destaque em todas as reflexões sobre o assunto e também presente na maioria dos códigos existentes na atualidade.

Outros aspectos referentes às melhores práticas abordados nos códigos de governança existentes estão ligados à composição e independência do conselho. No âmbito nacional, o Código do IBGC (2009) em sua última versão incorpora características importantes. A nova versão do referido código reduz a ênfase em questões já incorporadas na rotina das empresas e abre espaço para detalhar e atualizar aquelas que ainda não estão bem enraizadas como, por exemplo, a eficácia do conselho.

Dentre os principais itens inseridos na $4^{\mathrm{a}}$ edição do código do IBGC, podemos destacar as novas formas de participação dos stakeholders, com mais transparência e maior detalhamento da atuação do conselho de administração. No que se refere ao conselho de administração permanecem princípios fundamentais, como a separação das funções de presidente do conselho e presidente executivo. Sobre as características dos conselheiros há um item novo 
sobre disponibilidade de tempo, o qual recomenda ao conselheiro restringir o número de participação em conselhos e comitês para que possa exercer adequadamente sua função. Sobre o conselheiro independente há um detalhamento do conceito e da importância. Outro assunto relevante é a questão da remuneração que há recomendação de detalhamento e indicação para evitar estruturas de incentivo de remuneração que atrelem a remuneração do conselheiro à da gestão. O código também ressalta o ponto da necessidade do conselho de ter autonomia para fiscalizar e supervisionar a gestão e indica a divulgação, individual ou coletiva, do tipo de remuneração recebida pelos conselheiros: fixo, variável e benefícios. Em relação à evidenciação há incentivo a maior nível de transparência e frequência na divulgação de informações.

Tendo em vista que o contexto nacional e mundial mostram a necessidade de maior atenção a pontos cruciais sobre governança, pretende-se com esse estudo explorar mecanismos de governança com o intuito de verificar o impacto que esses mecanismos apresentam no grau de evidenciação das empresas. A recente preocupação com o conhecimento do funcionamento interno dos conselhos levaram os estudiosos a focarem alguns estudos na dinâmica do conselho de administração e os efeitos dos mecanismos de governança no nível de evidenciação das empresas.

Com o intuito de investigar quais as proxies para as variáveis de práticas recomendadas relativas ao CA que se destacam como mecanismos efetivos de governança corporativa foram analisados estudos com foco na efetividade do conselho.

\subsection{Efetividade do Conselho}

Alguns estudos tentaram modelar a dinâmica do conselho teoricamente (HUSE, 2005; NICHOLSON; KIEL, 2004; SUNDARAMURTHY; LEWIS, 2003; FORBES; MILLIKEN, 1999). Outros diversos estudos abordam mecanismos internos de governança como proxy da função de monitoramento do conselho esperada pelos acionistas, a efetividade do conselho também é tratada em termos de algumas características presentes nos conselhos como tamanho, independência, diversidade de conhecimentos e experiências entre os conselheiros, separação de papéis entre presidente do conselho e presidente executivo, disponibilidade de 
tempo (LEVRAU; VAN DEN BERGHE, 2007; JOHN; SENBET, 1998; NICHOLSON; KIEL, 2004; PETTIGREW; MCNULTY, 1998; DEFOND et al., 2005; HE et al., 2008).

Sobre a efetividade dos conselhos de administração, He et al. (2008) apresentam uma revisão sobre os trabalhos que investigam associações entre medidas de supervisão, como o conselho de administração e o comitê de auditoria, e a qualidade das informações financeiras disponíveis. Os autores destacam as variáveis que contribuem para a efetividade do monitoramento dos conselhos tais como: independência do conselho; algumas características dos conselheiros externos como o nível de propriedade dos conselheiros externos, tempo no cargo dos conselheiros e atividades adicionais dos conselheiros; dominância do presidente executivo. Destaca-se o papel de diferentes variáveis de governança corporativa no reforço de diferentes aspectos da qualidade dos relatórios financeiros. Algumas características do conselho e do comitê de auditoria podem contribuir para o efetivo monitoramento das demonstrações financeiras das empresas (HE et al., 2008). Esse trabalho deixa evidente que a efetividade do funcionamento do conselho de administração pode se tornar acessível por meio de outras características observáveis que se relacionam tanto com atributos dos conselheiros quanto com a estrutura de governança adotada pelas empresas.

O estudo de Levrau e Van Den Berghe (2007) levanta uma abordagem indireta da relação entre características do conselho e os resultados no desempenho da empresa. O intuito dessa pesquisa é aprofundar o conhecimento do conceito da efetividade do conselho suprimindo a relação direta entre características do conselho e resultados de desempenho. Os autores investigam - de um ponto de vista conceitual - a interrelação entre diversos critérios que se supõem importantes para a efetividade do conselho.

Os autores desenvolvem um modelo de efetividade do conselho que preenche algumas lacunas existentes nas pesquisas sobre conselho de administração. $\mathrm{O}$ modelo proposto se baseia fortemente na abordagem entrada-processo-saída utilizada em pesquisas de sistemas para investigar equipes organizacionais (LEVRAU; VAN DEN BERGHE, 2007). Os autores apresentam um diagrama para avaliação da efetividade dos conselhos explorando variáveis críticas que determinam a efetividade do conselho como tamanho, independência e diversidade do conselho, essas variáveis estão ligadas às variáveis intervenientes: coesão, debate e normas para conflitos. A Figura 1 representa um modelo de processo orientado que impacta os resultados da empresa e considera tanto atributos dos conselheiros como aspectos da estrutura de governança. 


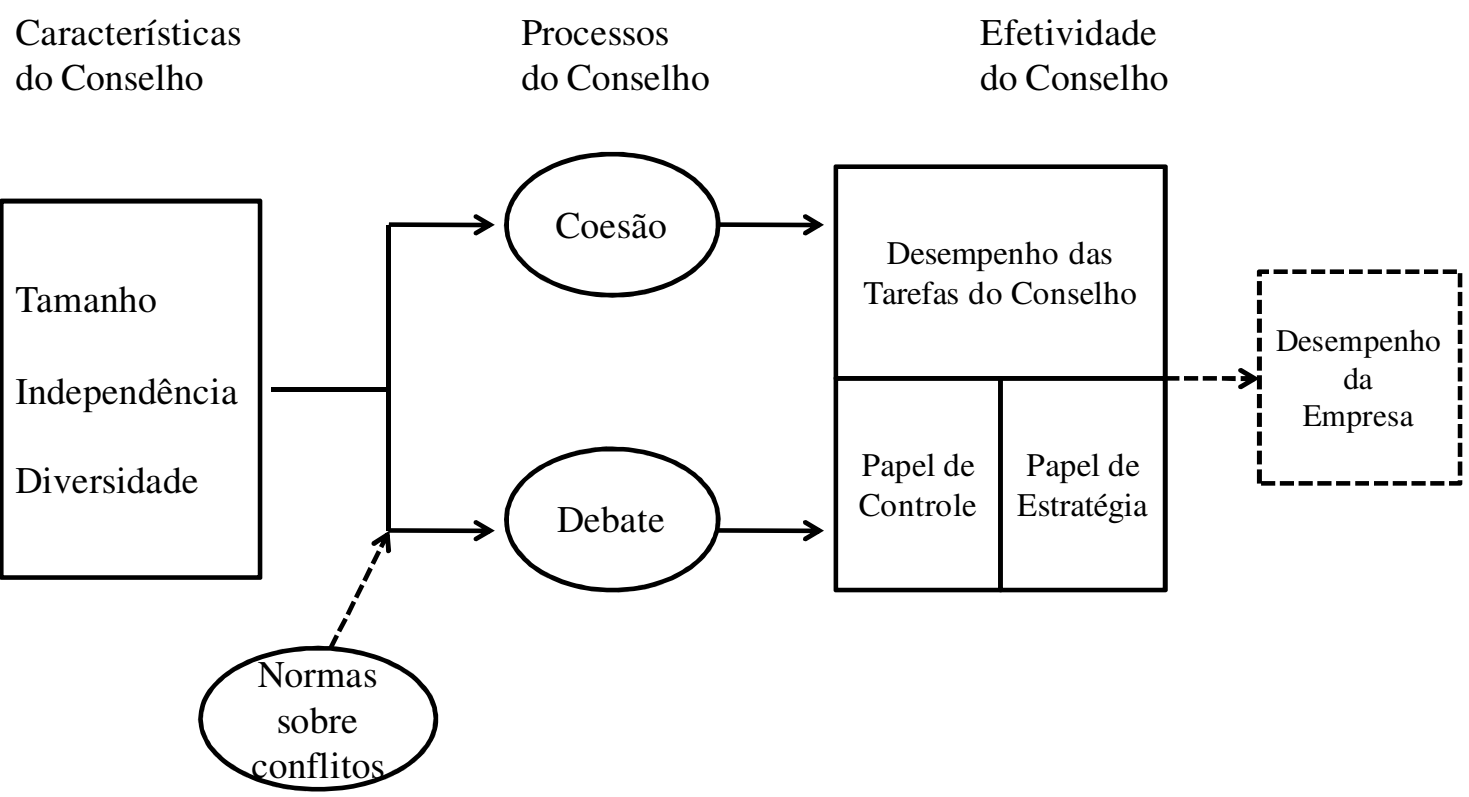

\section{Figura 1: Modelo de efetividade do conselho}

Fonte: Adaptado de Levrau e Van Den Berghe (2007).

Somente na última década acadêmicos começaram a sugerir que o conselho deveria se transformar de uma agregação indefinida de indivíduos para se torna um time efetivo (NADLER et al., 2006; NADLER, 2004; CARTER; LORSCH, 2004). Para o conselho se tornar um time, que opera em colegiado, é necessário um mínimo de coesão entre os membros do conselho. A visão de coesão apoia colaboração e comunicação entre os membros do conselho (LEVRAU; VAN DEN BERGHE, 2007). Membros do conselho devem encontrar maneiras para expor suas visões, para desafiar os pontos de vistas uns dos outros sem romper o código de harmonia. Outro ponto indispensável é o debate, que, segundo Eisenhardt et al. (1997), facilita a geração de ideias e promove oportunidade para criticamente aferir diversas alternativas e questionar falsas concepções. O estudo de Van Den Berghe e Levrau (2004) revela que conselheiros percebem a ocorrência de debates objetivos como um critério essencial para a efetividade do conselho. As hipóteses defendidas por Levrau e Van Den Berghe (2007) são: (i) aumento na independência do conselho irá elevar o debate; no entanto, aumento na independência do conselho é negativamente associado à coesão; (ii) o efeito da diversidade do conselho no debate será positivo, mas se o conselho se torna muito diversificado, o impacto no debate será negativo; e (iii) quanto mais diversificado são os conselheiros no conselho, menos coesão os membros do conselho irão vivenciar. 
Destaca-se que alguns pontos importantes são levantados no modelo como parte do caminho para a efetividade do conselho sugerindo melhor desempenho da empresa. Tais variáveis como tamanho, independência e diversidade são relevantes para o estudo do funcionamento interno do conselho e a decorrência da adoção de melhores práticas de governança por parte das empresas. Os autores consideram que a coesão e o debate são variáveis intervenientes, ou seja, coadjuvantes no processo que considera tanto características dos conselheiros como aspectos da estrutura de governança para a efetividade do conselho.

Roberts et al. (2005) argumentam que a chave para a efetividade do conselho está no nível em que os conselheiros atuam, individual e coletivamente, para proporcionar prestação de contas (accountability) aos investidores. "A prestação de contas é alcançada por diversos comportamentos, tais como, questionamento, desafios, discussão, informação, debates, encorajamento, averiguação, que são o foco principal de como os conselheiros buscam pela efetividade" (ROBERTS et al., 2005, p. 6). Tal prestação de contas pode ser evidenciada em termos de comportamentos que sugerem engajamento do conselheiro, suporte nas discussões com apresentação de desafios e envolvimento apesar do conselheiro ser tido como membro independente. Esses comportamentos podem ser acessados por meio de variáveis relacionadas com as habilidades, conhecimentos e experiências trazidas pelos conselheiros além da disponibilidade para envolvimento com os assuntos do conselho, com esses atributos presentes a tendência é de se criar um ambiente favorável ao debate contribuindo para a efetividade do conselho. O trabalho de Roberts et al. (2005) enfatiza o conhecimento sobre o trabalho dos conselheiros independentes e as condições em que eles contribuem para a efetividade do conselho. Os autores ponderam um ponto substancial sobre a habilidade dos conselheiros independentes de exercer espírito de independência, o que é a chave para o comportamento efetivo do conselho:

[...] embora a estrutura e composição do conselho, sejam visíveis a uma distância, em nossa opinião, isso pode condicionar, ao invés de determinar, a efetividade dos conselhos. A real efetividade do conselho, sugerimos, depende do comportamento dinâmico do conselho, e de como é desenvolvida a rede de relações interpessoais e de grupo entre os conselheiros no contexto de determinada empresa. (ROBERTS et al., 2005, p. 11$)^{2}$.

\footnotetext{
${ }^{2}[\ldots]$ whilst board structure and composition are visible from a distance, in our view, at best these condition, rather than determine, effectiveness. Actual board effectiveness, we suggested, depends upon the behavioural dynamics of a board, and how the web of interpersonal and group relationships between executive e non-executive is developed in a particular company context. (ROBERTS et al., 2005, p. 11).
} 
O trabalho de Nicholson e Kiel (2004) argumenta que um sistema de governança corporativa efetivo requer uma série de componentes para estar em estado de congruência e alinhamento. Os autores propõe um modelo geral que conceitualiza o conselho como um fenômeno social. Dessa forma, os conselhos apresentam muitos dos atributos de um sistema natural, então os autores propõe considerar o conselho como um sistema social aberto e dinâmico (NICHOLSON; KIEL, 2004). A abordagem de sistema social para conselho é uma maneira de unificar a teoria existente e as investigações empíricas de como o conselho impacta o desempenho da empresa. Um conselho efetivo terá um ajuste eficiente entre diversos elementos de seu capital intelectual a luz do papel que lhe é requerido para funcionar efetivamente. Resumidamente, existem cinco inputs para o sistema do conselho: o tipo de organização e seus objetivos; o sistema geral legal e a social que a empresa está envolvida; o sistema de governança da empresa; a história da empresa; e a estratégia da empresa. Juntos esses fatores determinam os requisitos de capital intelectual e papel do conselho.

Stewart (1997) apud Nicholson e Kiel (2004) define o capital intelectual como os recursos intelectuais, tais como informação, experiência, relacionamentos, rotinas e procedimentos que o conselho pode utilizar para criar valor. Como é ressaltado pela definição, o constructo captura os elementos fundamentais da composição do conselho que contribuem para a efetividade do desempenho do conselho. O capital intelectual do conselho oferece uma ampla variedade de atributos que pode impactar na efetividade da governança. São quatro subdomínios: capital humano, capital social, capital estrutural e capital cultural. O capital humano se relaciona no plano individual do conselheiro, representado pela experiência profissional, formação, conhecimento do setor, experiência em conselhos. O capital social se refere a rede de relacionamentos externos e internos à companhia também no nível individual do conselheiro. O capital estrutural se relaciona a políticas, cultura, procedimentos e normas do conselho. E o capital cultural está ligado às regras individuais de moral e motivação dos conselheiros (NICHOLSON; KIEL, 2004). O sistema está representado a seguir na Figura 2. 


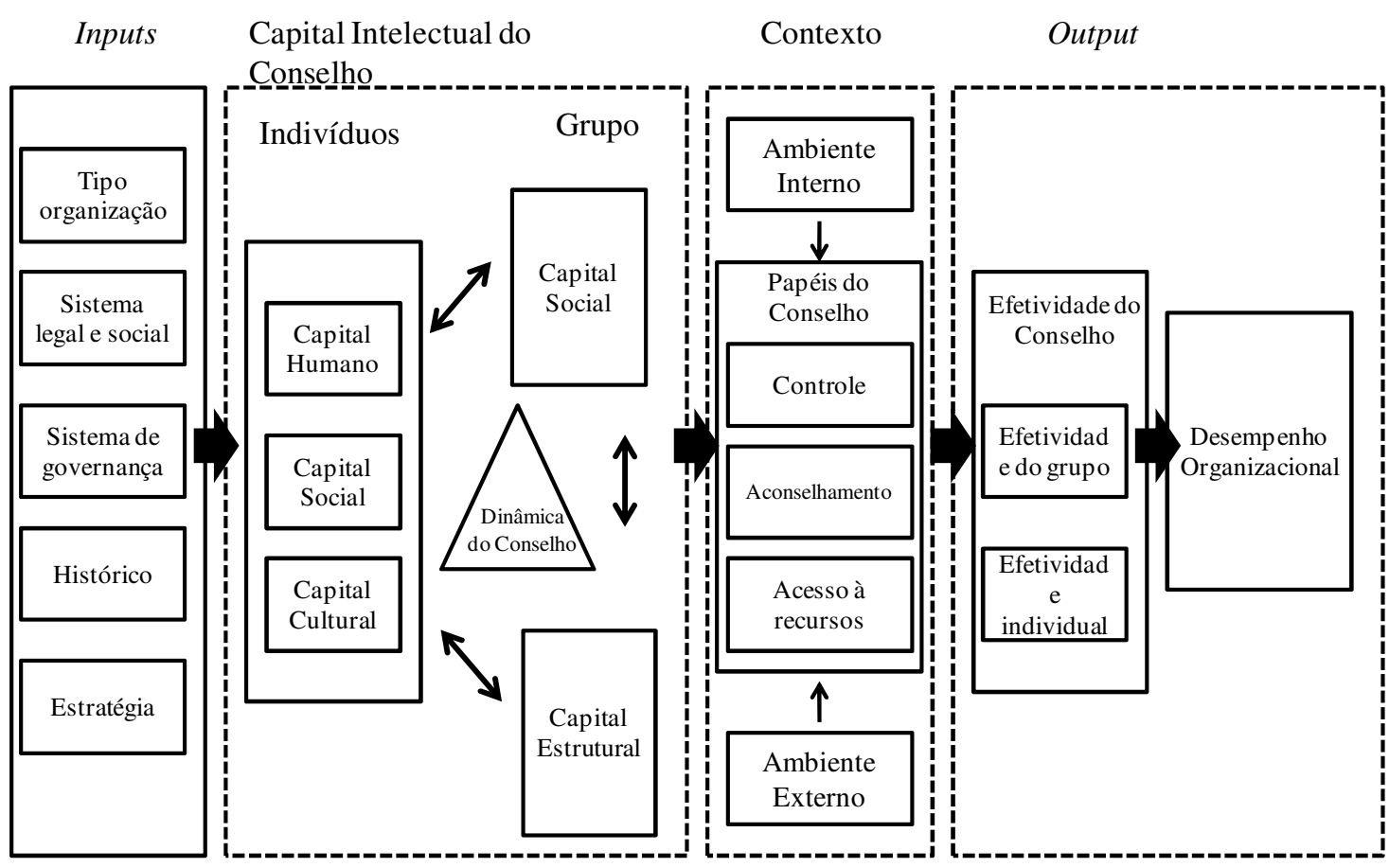

\section{Figura 2: Sistema de capital intelectual do conselho}

Fonte: Adaptado de Nicholson e Kiel (2004).

Ter um sistema é normalmente pré-requisito para pesquisa em ciências sociais - e isso é o ponto de partida introduzido pelo artigo. O sistema pode conduzir para o entendimento generalizado dos tipos de problemas que o conselho enfrenta e as causas desses problemas. De acordo com Nicholson e Kiel (2004), o sistema pode ser visto como um instrumento para determinar o desempenho do conselho e tem o potencial de melhorar o desempenho da empresa por meio do aperfeiçoamento da execução do papel do conselho. Também pode dar suporte ao conselho para avaliar a composição particular necessária para cada conselho e construir as relevantes intervenções relacionadas a processos para alcançar as necessidades e melhorar o desempenho do conselho.

Com o exposto pode-se observar que algumas variáveis, como independência, diversidade, disponibilidade de tempo entre outras, são citadas por diversos autores. Isso pode ser observado na Figura 3 que mostra um diagrama com as variáveis abordadas neste trabalho que podem influenciar a efetividade do conselho. 


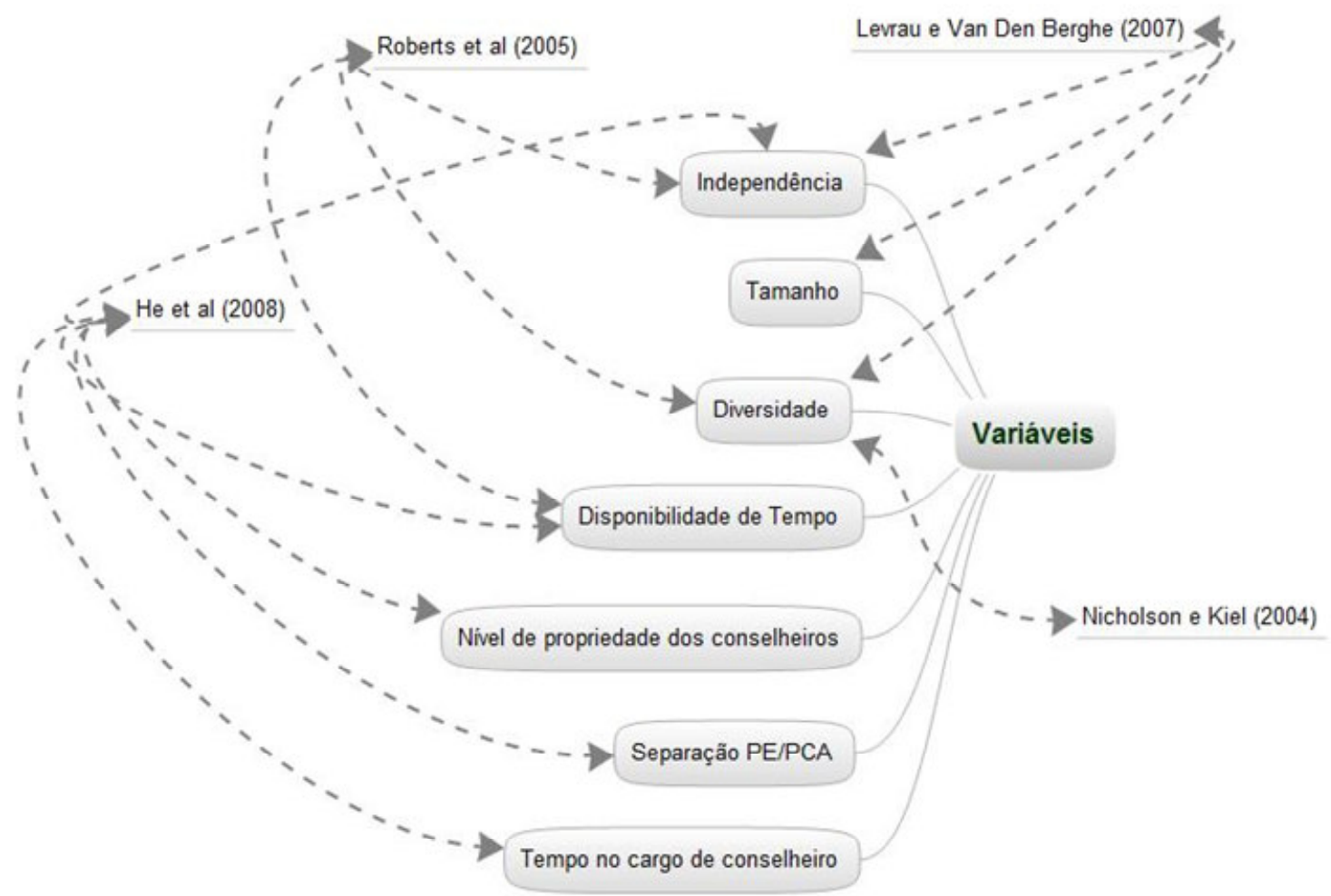

Figura 3 - Compilação das variáveis dos trabalhos sobre efetividade do conselho

\subsection{Práticas recomendadas de governança corporativa}

Os estudos sobre efetividade do conselho de administração apontam para muitas variáveis que podem influenciar o funcionamento efetivo do conselho de administração, algumas se relacionam com características dos conselheiros (diversidade de formação, participação em outros conselhos, tempo de permanência no conselho) e outras se referem à estrutura de governança das empresas (percentual de participação de conselheiros independentes, tamanho do conselho, independência do presidente do conselho, participação do presidente executivo no conselho, existência de comitês). As recomendações de melhores práticas de governança do IBGC (2009) contemplam alguns desses itens, como a independência dos conselheiros, a disponibilidade de tempo, a diversidade de conhecimentos por parte dos membros do conselho, a separação de papéis do presidente do conselho e do presidente executivo. Dessa forma, observa-se a relevância desses mecanismos para o funcionamento efetivo e dinamismo do conselho. 


\subsubsection{Independência}

A questão da independência do conselho não é um tema novo nas discussões de governança, é uma das recomendações mais indicada nos códigos de boas práticas de governança da maioria dos países (GREGORY, 2007). Em se tratando dos conselhos das empresas dos Estados Unidos, a recomendação de maioria de membros independentes é seguida há mais de 25 anos (BHAGAT; BLACK, 1998). Nos países europeus essa recomendação também é aceita pela maioria das empresas abordadas em estudos acadêmicos e de mercado (HEIDRICK \& STRUGGLES, 2005).

No Brasil, apesar do Código de Melhores Práticas do IBGC (2009) recomendar maioria de membros independentes nos conselhos, não é o que acontece na realidade. De acordo com pesquisa recente realizada pela KPMG e CEG (2008), não foi encontrado, em nenhuma amostra abordada na pesquisa, percentual de conselheiros independentes superior a $50 \%$. A pesquisa engloba empresas do Novo Mercado, empresas com emissão de ADR na bolsa de Nova York e amostra aleatória de empresas do segmento tradicional da Bovespa. Diante desse resultado, observa-se que a realidade em relação à quantidade de membros independentes nos conselhos de administração continua distante das recomendações dos principais códigos de governança internacionais e da recomendação nacional do IBGC.

No que concerne às pesquisas que envolvem a investigação da relação entre a participação de conselheiros independentes nos conselhos de administração e o valor e/ou desempenho das empresas, há indicação da importância dos conselheiros independentes, tendo em vista que sua presença auxilia os acionistas a lidar com o problema de agência. De acordo com Clarke (2006), se os conselheiros estão nos conselhos para monitorar efetivamente, eles devem ser independentes em relação aos executivos.

O trabalho de Santella et al. (2006) envolve o detalhamento das relações dos conselheiros independentes. Os autores investigaram se o percentual de conselheiros independentes indicado pelas empresas italianas era diferente do recomendado pelos códigos de governança corporativa da Itália e das recomendações do Comitê Europeu (European Commission). Os resultados evidenciaram diferenças significativas entre a recomendação do código italiano e do europeu em relação à realidade no âmbito empresarial (SANTELLA et al., 2006). Esse tipo de estudo ainda é pouco explorado no Brasil. 
Em países como o Brasil há características de concentração de propriedade, e nesse ambiente, de acordo com Valadares e Leal (2000), o principal conflito ocorre entre os acionistas minoritários e acionistas majoritários. Portanto, de acordo com Saito e Dutra (2002, p. 100), "nesses países, a independência do conselho dependeria da influência maior ou menor dos acionistas controladores sobre os membros do conselho, e não necessariamente da influência dos executivos, como em países em que a propriedade é dispersa.".

Pesquisas nacionais envolvendo conselheiros independentes incluem o trabalho de Saito e Dutra (2002) que buscaram identificar o perfil dos conselhos de administração de empresas listadas na Bovespa. Dentre os resultados, destaca-se a indicação de que os conselhos de administração são amplamente dominados por representante dos acionistas controladores. Além disso, ao dividir os conselheiros em quatro categorias - controlador, interno, afiliado e independente - verificou-se que os conselheiros independentes representam apenas $21 \%$ do total, o que sugere (isoladamente) não estar de acordo com recomendações do Cadbury Report e do IBGC, que recomendam a composição por maioria de conselheiros independentes.

Black et al. (2008) investigaram as práticas de governança práticas nas empresas brasileiras, ao examinarem 116 empresas listadas em 2005. Nos resultados foram identificadas áreas fortes e fracas em relação a essas práticas. Entre as fracas, destaca-se a independência do CA que é predominantemente formado por conselheiros internos à empresa ou representantes dos acionistas controladores.

A importância dos conselheiros independentes é defendida por vários autores (TIROLE, 2006; ROBERTS et al., 2005; LEVRAU; VAN DEN BERGHE, 2007; HE et al., 2008; DONNELLY; MULCAHY, 2008), além de ser uma recomendação de melhor prática de governança na maioria dos códigos existentes (GREGORY, 2007; IBGC, 2009). A racionalização para o argumento se baseia no fato dos conselheiros independentes serem monitores mais efetivos, pois não estão sujeitos a dominância por parte do presidente executivo já que mantém certa distância da gestão das empresas e podem fazer questionamentos que auxiliam no processo de tomada de decisão do conselho.

Do ponto de vista teórico, a perspectiva da teoria de agência sugere que os conselhos deveriam ser capazes de agir independentemente dos executivos e, portanto, deveriam apresentar preponderância de conselheiros independentes (VAN DEN BERGHE; LEVRAU, 
2004). Com outro ponto de vista, a teoria da administração (stewardship) afirma que executivos são bons administradores dos ativos das empresas. Os executivos não desapropriam recursos corporativos a nenhum preço, pois eles têm uma gama de motivos não financeiros, como satisfação intrínseca de sucesso em relação ao desempenho, necessidade de conquista e reconhecimento etc. De acordo com Van Den Berghe e Levrau (2004), seguindo esse racional, os conselhos deveriam ser dominados por conselheiros internos. Devido à divergência dos pontos expostos pelas duas teorias, a base para esta pesquisa será o racional da teoria de agência, a qual recomenda a presença de conselheiros independentes nos conselhos.

Segundo Roberts et al. (2005) um conselheiro independente pode trazer para o conselho objetividade, devido à relativa distância dos problemas rotineiros da companhia, além de experiências e conhecimentos adquiridos. A chave para a habilidade do conselheiro independente é utilizar essa objetividade e experiências para basear questionamentos e desafios para os executivos. Corroborando essa ideia, Levrau e Van Den Berghe (2007) argumentam que a ausência de vínculos estreitos com a empresa faz com que os conselheiros independentes sejam capazes e melhor posicionados ao abordar questões de certa distância e podem se manifestar livremente.

Ressalta-se a importância do mix entre conselheiros internos e externos com o intuito de minimizar conflitos entre os agentes. Conselheiros externos servem como monitores e conselheiros internos oferecem expertise sobre as características da empresa, expertise essa que é válida para o planejamento e desenvolvimento das operações (KLEIN, 2002). Espera-se que conselheiros internos sejam monitores menos efetivos porque estão abaixo do presidente executivo na hierarquia, de acordo com He et al. (2008). Um ponto contrário a presença de executivos no conselho, ou seja, conselheiros internos, refere-se ao relacionamento e lealdade desses com o presidente executivo, adicionalmente ao receio de retaliação, que poderia prejudicar relações futuras de trabalho ou perspectivas de carreiras, impedindo que conselheiros internos pronunciem abertamente seus desacordos durante as discussões no conselho (BAYSINGER; HOSKISSON, 1990).

Conselheiros externos e independentes são percebidos como um instrumento para monitorar o comportamento dos executivos resultando em mais evidenciação voluntária de informações empresariais devido a função de controle desempenhada pelos conselhos (HO; WONG, 2001). Fama e Jensen (1983) argumentam que quanto maior a proporção de conselheiros 
independentes no conselho, mais efetivo o conselho será em monitorar o oportunismo dos executivos, e as empresas podem esperar maior nível de evidenciação voluntária. Ho e Wong (2001) citam a pesquisa de Forker (1992) para mostrar que um percentual maior de conselheiros independentes nos conselhos eleva o monitoramento da qualidade da evidenciação financeira e reduz os benefícios de retenção de informações.

Donnelly e Mulcahy (2008) mostram que a presença de conselhos independentes facilita a redução de assimetria informacional entre acionistas e executivos. Os resultados suportam a atenção dada pelos reguladores à proporção de conselheiros independentes nos conselhos. No entanto, custos e benefícios para evidenciação variam entre as empresas. Desconsiderando os conceitos da teoria de agência e as recomendações dos reguladores, empresas irão formular suas políticas de evidenciação concernente aos custos e benefícios marginais no que se refere à presença de conselheiros independentes no conselho (DONNELLY; MULCAHY, 2008). Pesquisas recentes (ENG; MAK, 2003; DONNELLY; MULCAHY, 2008) sugerem que conselheiros independentes são fatores cruciais para a composição do conselho, afetando a efetividade e o papel de monitoramento do conselho.

Em pesquisa realizada com investidores institucionais pela ISS - Institutional Shareholders Services em 2006, destaca-se a importância dada a questão da estrutura, composição e independência do conselho de administração, que foi relatada pelos investidores institucionais como um relevante assunto sobre governança no curto prazo (IFC, 2010).

\subsubsection{Separação dos papéis de presidente executivo e presidente do conselho}

Outra recomendação de melhor prática de governança que vem tomando força nos últimos anos é em relação à separação dos papéis de presidente do conselho e presidente executivo. Os códigos de boas práticas de governança da maioria dos países indicam que os cargos devem ser ocupados por pessoas distintas (GREGORY, 2007). O código do IBGC (2009) sugere a adoção dessa prática pelo seguinte motivo:

As atribuições do presidente do Conselho são diferentes e complementares às do diretor presidente. Para que não haja concentração de poder, em prejuízo de supervisão adequada da gestão, deve ser evitado o acúmulo das funções de presidente do Conselho e diretor presidente pela mesma pessoa.

No âmbito nacional, em recente pesquisa realizada pela KPMG e CEG (2008), constatou-se que em $79 \%$ das companhias do Novo Mercado os cargos de diretor-presidente e presidente 
do conselho de administração são ocupados por pessoas distintas. Na revisão do regulamento do Novo Mercado da Bovespa uma das sugestões é vedar a ocupação do citado cargo pela mesma pessoa, a tendência é que em breve esse percentual seja de $100 \%$. Verifica-se que há uma convergência de recomendações em relação à ocupação dos cargos por pessoas distintas.

No survey realizado por Black et al. (2008), com dados de empresas brasileiras listadas de 2005, esse resultado é corroborado. Os autores evidenciaram que 71\% da amostra têm pessoas diferentes ocupando os cargos de presidente executivo e presidente do conselho de administração.

Defensores da teoria de agência favorecem a separação dos papéis de presidente executivo e presidente do conselho. Ao separar esses papéis há diluição do poder do presidente executivo e redução do potencial de dominação dos executivos no conselho (VAN DEN BERGHE; LEVRAU, 2004) além de proporcionar as verificações essenciais e necessárias sobre o desempenho dos gestores (HANIFFA; COOKE, 2000). Contrariamente, a teoria da administração (stewardship) sugere que a dualidade, presidente executivo servindo também como presidente do conselho, oferece liderança unificada para a empresa, constrói confiança e estimula a motivação pelo desempenho (MUTH; DONALDSON, 1998), além de facilitar ao presidente executivo o alcance dos objetivos devido a menos interferências e reforço do papel de liderança da empresa e do conselho (HANIFFA; COOKE, 2000).

A separação dos papéis de presidente do conselho e presidente executivo é justificada em termos de limitação do poder dos executivos e de ênfase na independência dos conselheiros (CADBURY, 1992). Roberts et al. (2005) argumentam que a separação dos papéis também significa que o presidente do conselho terá tempo e inclinação para criar condições para que os conselheiros independentes possam ser efetivos.

A pessoa que ocupa ambos os cargos tende a reter informações desfavoráveis dos membros externos, de acordo com Ho e Wong (2001). Uma personalidade dominante nos dois papéis se coloca como uma ameaça para a qualidade do monitoramento e é prejudicial à qualidade de evidenciação (FORKER, 1992 apud HO; WONG, 2001). 


\subsubsection{Diversidade}

Além da importância da existência de conselheiros independentes, outros atributos relacionados aos conselheiros são importantes para capturar o efeito da adoção das melhores práticas de governança na dinâmica e funcionamento do conselho e, consequentemente, na efetividade do conselho. Esses atributos estão relacionados à diversidade de formação, qualificação, diversidade etária e disponibilidade de tempo.

O código do IBGC (2009) destaca algumas competências que o conselho deve buscar reunir: (i) experiência de participação em outros conselhos; (ii) experiência como executivo sênior; (iii) experiência em gestão de mudanças e administração de crises; (iv) experiência em identificação e controle de riscos; experiência em gestão de pessoas; (v) conhecimentos de finanças; (vi) conhecimentos contábeis; (vii) conhecimentos jurídicos; (viii) conhecimentos dos negócios da organização; (ix) conhecimentos dos mercados nacional e internacional; (x) contatos de interesse da organização. Observa-se que a diversidade de conhecimentos e experiências é relevante para a execução da função do conselho.

Kang et al. (2007) definem a diversidade do conselho como a variedade na composição do conselho. São duas as categorias de diversidade - diversidade observável, que é detectável prontamente pelos atributos dos conselheiros e a diversidade menos evidente, como a experiência dos conselheiros. A diversidade observável inclui nacionalidade, gênero e idade, enquanto a diversidade menos evidente abrange experiências de formação e profissional, conhecimento de setores, e associações organizacionais. Algumas vantagens da diversidade do conselho incluem fomento de melhor entendimento do mercado, maior inovação e criatividade. Além disso, a diversidade do conselho pode levar ao desenvolvimento de relações globais mais efetivas e elevar o espírito de independência dos conselheiros, pois, de acordo com Arfken et al. (2004), pessoas com diferenças de gêneros, etnia ou experiências culturais podem apresentar questionamentos que não surgiriam de pessoas com experiências tradicionais.

Levrau e Van Den Berghe (2007) afirmam que os conselhos têm o potencial de oferecer uma associação de expertises, pois os membros tenderão a ter uma variedade de experiências e formação educacional e profissional mais ampla e podem representar conhecimentos e habilidades mais especializadas. Os próprios conselheiros enfatizaram a importância de se ter uma mistura diversificada de pessoas no conselho de administração com o objetivo de ser 
efetivo (VAN DEN BERGHE; LEVRAU, 2004). A diversidade entre os conselheiros supostamente melhora o debate devido à evidente razão de que a diversidade é associada com diferentes experiências de vida e, portanto, de perspectivas.

O conselho deveria compreender uma mistura de pessoas com diferentes personalidades e níveis educacionais, profissionais e conhecimento, mas eles devem ser complementares. Um conselho composto apenas por 'clones' não funciona e é até perigoso (VAN DEN BERGHE; LEVRAU, 2004). O conselho deve buscar um equilíbrio entre os graus de formação, conhecimento e experiência dos conselheiros. De acordo com Van Den Berghe e Levrau (2004), membros do conselho devem ter o mínimo de conhecimento sobre contabilidade, direito e o setor da empresa. O requisito de ter ao menos um expert em contabilidade no conselho está baseado na ideia de melhora na efetividade de monitoramento segundo He et al. (2008).

A composição do conselho deve criar um ambiente que seja adequado para que este órgão de tomada de decisão exerça seu papel e adicione valor para a empresa e todos os acionistas. Para tanto é destacado pelo IFC (2010, p. 73), no livro sobre as experiências das empresas do círculo de companhias da América Latina, que:

[...] a escolha de membros que tenham um conjunto específico de experiências e aptidões com um mix correto das duas. A soma de experiências e aptidões diversificadas contribuirá para o conhecimento, visão estratégica e julgamento apropriado para que o conselho cumpra suas responsabilidades.

A pesquisa de DeFond et al. (2005) testa se o mercado reage favoravelmente a indicação de conselheiros com expertise em finanças para o comitê de auditoria. Posteriormente separamse os tipos de expertise em contadores e não contadores para avaliar o efeito de cada tipo de expert. Encontram reação positiva do mercado quando um conselheiro com expertise contábil é indicado ao comitê de auditoria mas não há reação do mercado quando da indicação de não contadores. Os resultados são consistentes com as habilidades financeiras de profissionais contábeis, mas não com ampla habilidade de não contadores, o racional está no aperfeiçoamento da capacidade do comitê de auditoria de garantir alta qualidade ao reportar as demonstrações. Os resultados são consistentes com o papel complementar dos experts com a governança corporativa, talvez pelo fato de ambientes fortes em governança corporativa auxiliarem o canal pelo qual o expert eleva o valor para os acionistas. Os resultados sugerem que experts financeiros e contábeis podem melhorar a governança corporativa, a habilidade para tal fato dependera do contexto (DEFOND et al., 2005). 
O estudo de Krishnan e Lee (2008) encontra evidências que a presença de especialistas em contabilidade no comitê de auditoria complementa estruturas de governança corporativa forte nas empresas. Segundo estes autores, o benefício de se ter um membro com especialização em contabilidade no comitê de auditoria é a sua capacidade de supervisionar os controles contábeis e demonstrativos financeiros da empresa, evitando, assim, possíveis falhas de comunicação, litígios e vigilância dos órgãos reguladores de mercado (KRISHNAN; LEE, 2008). Do exposto é possível sugerir que o mesmo racional possa valer para a presença de experts em contabilidade no conselho de administração, esses profissionais teriam a capacidade de elevar o nível de qualidade na evidenciação das demonstrações ao mercado.

Em pesquisa realizada no âmbito nacional, Mendes-da-Silva et al. (2007) analisaram a composição dos conselhos de administração de empresas listadas na Bovespa, no ano de 2004, pertencentes a dois dos principais setores industriais brasileiros (Alimentos \& Bebidas e Energia Elétrica). Os resultados evidenciaram pouca diversidade em relação à formação dos conselheiros, havendo predominância de conselheiros com formação em Engenharia (35,9\%). Os autores destacam que para o entendimento do papel do conselho devem ser considerados vários elementos: (i) a estrutura do conselho: seu tamanho, liderança e comitês que requerem para realizar seu papel; (ii) o mix de composição do conselho: a experiência, as habilidades e outros atributos de cada um de seus membros.

A pesquisa de Almeida (2008) também contempla o tema e inova ao explorar as qualidades dos conselheiros das empresas brasileiras com ADR negociadas na NYSE e relacioná-las com o valor das empresas. Os resultados encontrados evidenciaram que conselhos de administração com altos atributos de qualidade podem agregar valor à empresa, principalmente atributos relacionados ao tipo de profissional que compõe o conselho, presença de contadores no conselho e conselheiros com formação de alto nível como mestrado, doutorado ou programas executivos.

Em relação à diversidade de características e background dos conselheiros, Black et al. (2008) encontraram razoável diversidade nos conselhos pesquisados em 2005. Em muitas empresas da amostra havia conselheiros com experiência financeira ou contábil, conselheiros com formação em Direito também eram comuns. Em cerca de $25 \%$ das empresas privadas havia um político ou ex-funcionário do governo em seus conselhos. Por outro lado os acadêmicos aparecerem em menor demanda. 
Conselhos com pouca pluralidade tendem a se tornar fóruns de debates monotemáticos e pouco produtivos. A diversidade pode ser considerada essencial para tornar o processo de tomada de decisão mais ágil e eficiente, com a diversidade de conselheiros há potencialmente mais questionamentos e debates aprofundados que auxiliam o processo decisório.

Pouco se trata em relação à idade no código do IBGC (2009), na verdade, a importância maior é dada aos requisitos de conhecimento e experiências dos conselheiros. A idade se torna um fator de peso relativo. No entanto, no que se refere à diversidade etária alguns autores destacam que não é incomum observar que a maioria dos membros do conselho é bem formado, maduro, com experiência, e, consequentemente, de meia-idade (KANG et al., 2007). Mas a necessidade do conselho ter amplitude etária se baseia nas diferentes contribuições e perspectivas que os grupos de diferentes idades podem trazer ao conselho. Enquanto o grupo mais velho oferece experiência, sabedoria, e usualmente os recursos econômicos, o grupo intermediário tem as maiores posições de responsabilidades ativas em empresas e na sociedade, ao passo que o grupo mais jovem tem energia e direcionamento para o sucesso e planejam o futuro antecipadamente (KANG et al., 2007).

Em relação ao gênero, sugere-se que há duas vantagens de se ter mulheres no conselho: (i) mulheres não fazem parte da rede social masculina, o que permite a elas serem mais independentes (KANG et al., 2007); (ii) elas podem ter melhor entendimento do comportamento do consumidor, das necessidades dos clientes, e das oportunidades para a empresa em alcançar tais necessidades (BRENNAN; MCCAFFERTY, 1997).

A diversidade de gênero ocasiona maior amplitude de perspectivas e suscita mais alternativas para solução de problemas devido às diferenças de modelos, atitudes, crenças e visões dos diferentes gêneros (HILLMAN et al., 2007). Segundo os autores, a reputação e credibilidade da empresa no mercado de trabalho interno e externo podem ser aprimoradas com a inclusão de mulheres nos conselhos.

A existência de mulheres nos conselhos ainda é pouco expressiva, alguns países como Suécia lideram com percentual de $21 \%$ segundo estudo da Heidrick \& Struggles (2007). Houve um aumento de $15 \%$ no número de mulheres nos conselhos da Europa, no entanto, esse aumento é a partir de uma base muito baixa de 8,4\% em 2005 (HEIDRICK \& STRUGGLES, 2007). A falta de diversidade de gênero continua a ser uma grande preocupação, 39\% das empresas europeias ainda não têm mulheres nos conselhos de administração (HEIDRICK \& 
STRUGGLES, 2007). Nos Estados Unidos, em amostra das 500 empresas da Fortune, 90\% das companhias têm ao menos uma conselheira e as mulheres ocupam $14.7 \%$ das posições nos conselhos (CATALYST, 2005). No Brasil, o estudo de Mendes-da-Silva et al. (2007) analisando a composição dos conselhos de administração de dois setores (Alimentos \& Bebidas e Energia Elétrica) de empresas listadas na Bovespa, evidenciou a predominância de conselheiros do sexo masculino $(91,9 \%)$.

\subsubsection{Disponibilidade de tempo}

Uma condição também muito importante ao se considerar um candidato a conselheiro é a disponibilidade de tempo. O código do IBGC (2009) inova ao trazer em suas recomendações o cuidado com o comprometimento e participação dos conselheiros. Citando o próprio código:

Para exercer esse papel, o conselheiro deve observar minuciosamente os compromissos pessoais e profissionais em que já está envolvido e avaliar se poderá dedicar o tempo necessário ao novo conselho. A participação de um conselheiro vai além da presença nas reuniões do conselho e da leitura da documentação prévia (IBGC, 2009).

Alguns trabalhos abordam esses atributos em termos de disponibilidade de tempo, devido à atuação limitada nas decisões da empresa, e por consequência na defesa dos interesses dos acionistas, causada pela participação em diversos conselhos - três ou mais conselhos (FICH; SHIVDASANI, 2004). Os autores Fich e Shivdasani (2004) identificaram associação entre empresas com conselheiros independentes excessivamente ocupados e fraca governança corporativa e ainda fraca rentabilidade operacional.

Morck et al. (1998) argumentam que o monitoramento dos executivos requer esforço e tempo. Com o aumento das atividades adicionais dos conselheiros há também aumento da demanda de tempo e o esforço diminui o montante de atenção que os conselheiros podem devotar para monitorar a empresa. John e Senbet (1998) citam que Noe e Rabello (1996) encontram resultados que a efetividade do conselho é reduzida pelo interlocking dos conselheiros. Dessa forma, um maior número de atividades adicionais estará associado com menor qualidade de monitoramento (HE et al., 2008).

O trabalho de Santos et al. (2009) apresenta evidências que o interlocking é uma prática comum no Brasil nas empresas listadas. Adicionalmente, o nível de interlocking nos 
conselhos está associado com conselhos maiores, estrutura acionária mais dispersa, e empresas maiores. Esses autores consideram os conselhos como ocupados (busy board) quando a maioria dos conselheiros externos trabalha em três ou mais empresas. O nível de dedicação e comprometimento dos conselheiros pode ser condicionado pela participação em múltiplos conselhos. Apesar da participação dos conselheiros em diversos conselhos trazer mais contatos e experiências para os conselhos, os conselheiros podem não desempenhar seus papéis efetivamente (SANTOS et al., 2009).

Segundo Mendes et al. (2008) torna-se difícil dedicar tempo e esforço para atender com maior profundidade as particularidades da empresa e desempenhar adequadamente o papel de monitor quando um conselheiro ocupa diversas posições em diversos conselheiros.

\subsubsection{Comitês}

As boas práticas de governança corporativa recomendam que o conselho de administração crie comitês para assuntos específicos, que se dediquem a áreas que requeiram estudos mais profundos para subsídio de decisões do conselho. De acordo com o Código do IBGC (2009) os comitês são órgãos acessórios ao CA, tendo como função a análise em profundidade de matérias específicas. Os comitês estudam os assuntos de sua competência e preparam as propostas ao conselho, porém só o CA pode tomar decisões.

A existência de comitês no âmbito do CA é prática comum no funcionamento dos conselhos nos Estados Unidos e na Inglaterra. A adoção de membros do conselho de administração independentes se aplica principalmente nos comitês de fiscalização.

No Reino Unido, o código de melhores práticas (Combined Code, 2008) recomenda que as empresas tenham comitês de Auditoria, Remuneração e Nomeação para auxiliar o conselho de administração, a recomendação avança na composição do comitê de Auditoria e de remuneração devendo ser compostos totalmente de conselheiros independentes. Nos Estados Unidos, com o advento da Sarbanes-Oxley passou a ser obrigatória a existência do comitê de Auditoria com recomendação de presença de especialista em finanças e composto por conselheiros independentes. As regras da NYSE também incluem a exigência de existência de comitê de Remuneração e Nomeação para empresas norte-americanas, no entanto, essas regras não são aplicáveis às empresas estrangeiras que negociam seus ADRs nesta bolsa. 
$\mathrm{Na}$ Europa em pesquisa realizada por Heidrick \& Struggles (2007) englobando 294 empresas de 10 países, os resultados referentes à existência de comitês são expressivos. O comitê de Auditoria existe em 98\% das empresas pesquisadas, o comitê de Remuneração existe em 95\% e de Nomeação em 90\%. Resultados de pesquisas com empresas norte-americanas (S\&P 500), reportado pelo relatório de SpencerStuart (2009) evidenciam que 100\% das empresas da amostra têm comitê de Auditoria e Remuneração e $99 \%$ têm comitê de Nomeação/Governança.

Dentre os comitês recomendados pelos códigos internacionais e nacionais está o Comitê de Auditoria, recomendado inclusive pelo Código do IBGC (2009), cuja especialização vai subsidiar o conselho de administração nos vários assuntos relativos à prestação de contas, divulgação, ambiente de controle e relacionamento com os auditores. No caso do Comitê de Auditoria, recomenda-se que ao menos um integrante tenha experiência na área contábil ou de auditoria. Outro comitê importante e também recomendado pelo Código do IBGC (2009) é o de Remuneração. É atribuição deste comitê discutir assuntos relativos à sucessão, remuneração e desenvolvimento de pessoas, assim como o processo de avaliação do CA e dos conselheiros (IBGC, 2009).

No Brasil, os comitês do CA predominantes também foram objetos de estudo, na pesquisa da KPMG e CEG (2009) os resultados indicaram predominância nas empresas do Novo Mercado dos comitês de Auditoria (35\%), Remuneração (23\%) e Governança (5\%); nas empresas com emissão de ADR Remuneração (50\%), Auditoria (47\%), Gestão de Riscos (22\%) e Governança (16\%); no entanto, nas empresas tradicionais a existência de comitês é inferior, comitês de Auditoria (24\%) e de Remuneração (11\%). Já na pesquisa de Guerra (2009) evidenciou-se predominância de comitês de Auditoria (26\%), Planejamento Estratégico (14\%), Remuneração (12\%) e Governança e Nomeação (6\%).

A existência de comitês é abordada nas pesquisas de Silveira et al. (2007) como um dos parâmetros para averiguar o índice de governança corporativa e Guerra (2009) como parte do questionário utilizado para verificar os papéis do CA.

Na Figura 4, apresenta-se uma compilação dos trabalhos revisados e a indicação das variáveis envolvidas nesses trabalhos. Verifica-se a por meio da revisão da literatura a relevância dessas variáveis. Em decorrência disso, essas serão as principais variáveis desta pesquisa, sendo utilizadas como direcionadores de recomendações de governança corporativa relativas ao CA. 


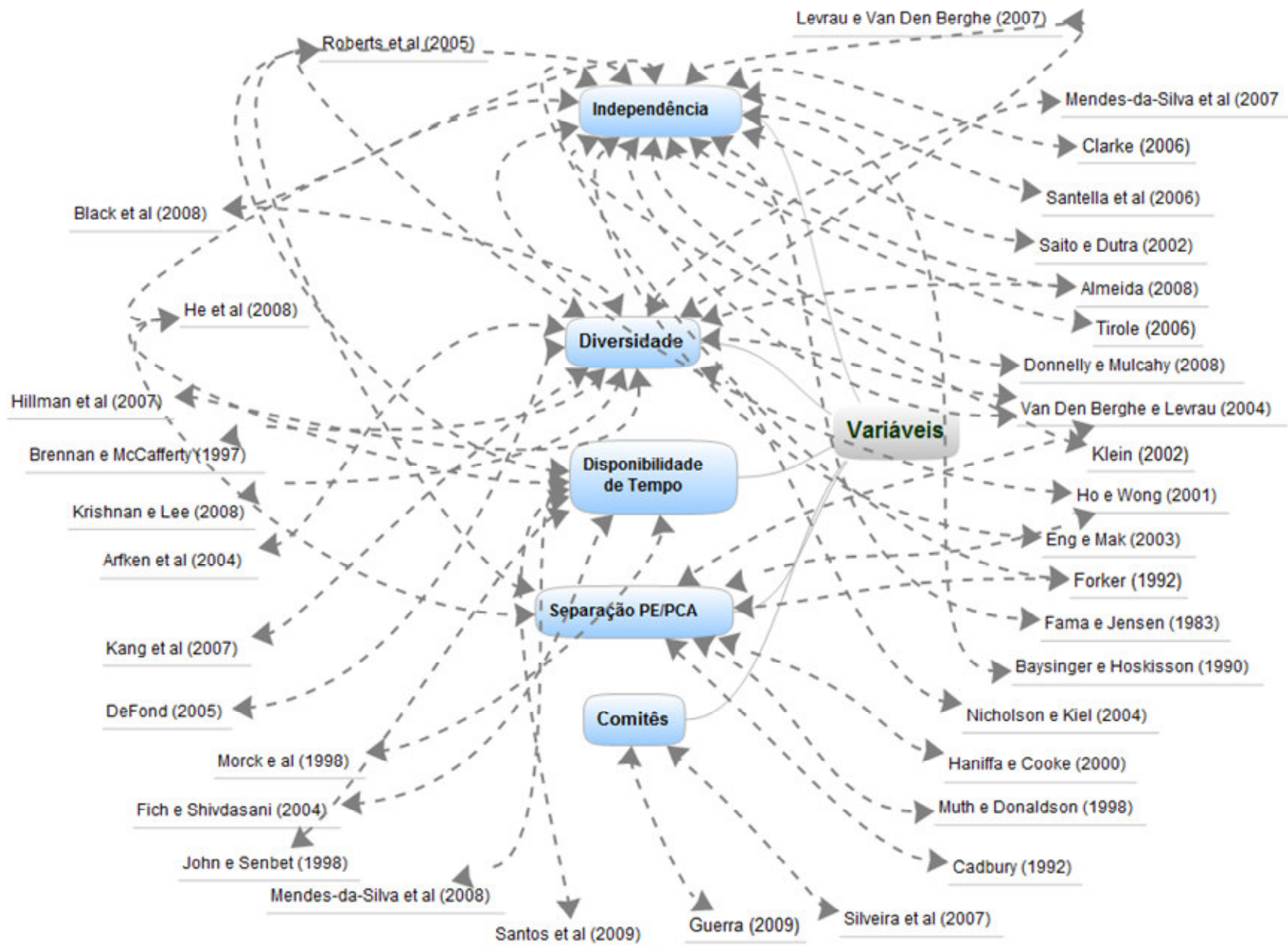

Figura 4 - Compilação das variáveis de melhores práticas recomendadas 


\subsection{Nível de Evidenciação}

Transparência e evidenciação são elementos chave de qualquer bom modelo de governança corporativa. A evidenciação das empresas geralmente pode ser classificada em obrigatória ou voluntária. Espera-se que as empresas evidenciem informações voluntárias para transparecer suas atividades aos participantes do mercado. A transparência está enquadrada nos sistemas sugeridos pelo IBGC (2009), os quais sustentam a governança corporativa: equidade (fairness); transparência (disclosure); prestação de contas (accountability); e compliance ou obediência e cumprimento das leis. É um assunto relevante diante o cenário atual.

A exigência de padrões mais altos de abertura de informações está sendo feita por diversos órgãos reguladores como CVM (Comissão de Valores Mobiliários), SEC (Securities and Exchange Commission). Não obstante, as empresas têm apresentado divulgação de informações voluntariamente com a finalidade de se diferenciar no mercado de capitais. A intenção da divulgação voluntária de informações é a de manter um relacionamento adequado com o mercado e captar recursos dos investidores quando necessário. Segundo Jensen e Meckling (1976) os gestores das empresas teriam incentivos para minimizar os custos de monitoramento e assim tenderiam a divulgar informações voluntariamente. Além disso, um maior nível de evidenciação poderia diminuir a assimetria informacional entre gestores e investidores.

Outro motivo para a disseminação de informações segundo Souza (1996), no caso de mercados de capitais menos desenvolvidos, é a conquista de credibilidade entre os investidores do mercado. A igualdade de condições de acesso a informações é condição essencial para atrair mais recursos do mercado de capitais. O autor também defende a redução da assimetria informacional entre os investidores e diminuição do risco de liquidez por meio do disclosure de informações.

O trabalho de Healy e Palepu (2001) aborda diferentes dimensões relacionadas à teoria sobre disclosure: (i) O papel do disclosure para o mercado de capitais; (ii) A regulação relacionada ao disclosure; (iii) O papel dos auditores e intermediários no processo de disclosure; (iv) Fatores relacionados às decisões de disclosure; (v) Consequências das decisões de disclosure. No que se refere ao papel do disclosure para o mercado de capitais, os estudos partem do pressuposto que mesmo em um mercado eficiente, os gestores detêm informações superiores 
em relação ao investidor externo. Assim, os gestores regularmente enfrentam a decisão de equilibrar o grau de evidenciação disponibilizado ao mercado de capitais com o nível de informações que eles detêm e a atitude dos gestores em relação à evidenciação de informações muda de acordo com a percepção custo-benefício envolvida no processo.

Verrecchia (2001) argumenta que é do interesse da companhia reduzir a assimetria informacional a fim de buscar a diminuição do custo de capital ao emitir ações ou títulos. Dessa forma, os gestores, que pretendem se utilizar do mercado de capitais para captar recursos, possuem incentivos para disponibilizar informação voluntariamente com o objetivo de diminuir a assimetria informacional e reduzir o custo de captação de recursos da empresa. Uma das maneiras de redução da assimetria se dá pelo comprometimento de apresentar uma política de alto nível de evidenciação por meio de disponibilização de informações referentes a regras de transações comerciais, políticas adotadas pela empresa, adoção de normas contábeis transparentes entre outros.

Em relação aos fatores relacionados às decisões de disclosure, Watts e Zimmerman (1986) observam que os gestores das empresas fazem comparação entre o custo de disponibilizar as informações com o efeito que a disponibilização desta informação causaria no valor de mercado da empresa. Neste sentido, a evidenciação voluntária de informações aconteceria quando os gestores avaliassem que o efeito da disponibilização da informação no valor de mercado da empresa seria superior ao custo de evidenciação da informação. Caso contrário, as empresas não divulgam voluntariamente informações e nesse caso seria necessário algum tipo de regulação para ter a obrigatoriedade de disponibilização de informações.

As consequências do aumento da evidenciação voluntária por parte das empresas são: elevação da liquidez das ações, diminuição do custo de capital e aumento da cobertura por parte dos analistas de mercado (HEALY; PALEPU, 2001).

Surveys de opiniões de investidores destacam a importância da transparência e evidenciação em um bom sistema de governança corporativa. Adicionalmente, os sistemas de rating de governança incluem aspectos de transparência e evidenciação como parte de uma avaliação central de governança corporativa (THE RELATIONSHIP, 2002). Sem transparência e evidenciação, acionistas e stakeholders não seriam capazes de estimar como, e de que maneira, a companhia está sendo administrada. Portanto, a prestação de contas e evidenciação são instrumentos significativos para que usuários externos possam avaliar seus investimentos. 
Teoricamente o impacto de mecanismos internos de governança na evidenciação das empresas pode ser complementar ou substituto. Se for complementar, a teoria da agência prediz que maior extensão de evidenciação é esperada já que a adoção de mais mecanismos de governança irá fortalecer o controle interno das companhias e oferecer um "pacote de monitoramento intenso" para a empresa reduzir comportamentos oportunistas e assimetria informacional (JENSEN; MEKLING, 1976; HO; WONG, 2001). Os autores defendem que em ambientes de monitoramento intensos, executivos não tendem a reter informação para seu próprio beneficio o que levaria ao aprimoramento na abrangência da evidenciação e na qualidade das demonstrações financeiras. Caso seja substituto, empresas não irão oferecer mais evidenciação devido aos efeitos dos mecanismos de governança, visto que um mecanismo pode substituir outro, de acordo com Ho e Wong (2001). Empresas com maior nível de evidenciação apresentariam pior estrutura de governança, dessa forma o menor monitoramento interno seria compensado pela transparência na evidenciação e com isso atrairia investidores externos.

Nos trabalhos empíricos há evidências de relação entre alguns mecanismos de governança relacionados ao CA e o nível de evidenciação. Wright (1996) evidencia que empresas com maior nível de evidenciação, mensurado por meio de rating da percepção de disclosure de analistas financeiros publicado no "Reports of the Association for Investment Management and Research Corporate Information Committee" (AIMR Reports), são aquelas que possuem menor percentual de membros do conselho associados à família dos gestores ou que mantenham negócios com a companhia (membros externos que tem algum vínculo com a administração, classificados na "área cinza" - grey director).

Haniffa e Cooke (2000) argumentam que o CA deve ser o órgão responsável pela condução do nível de transparência da empresa. Nesse sentido, investigam se governança corporativa, atributos específicos dos conselheiros e características específicas das empresas são possíveis determinantes do disclosure voluntário de empresas da Malásia. Os autores sugerem as possíveis relações entre variáveis relacionadas com governança corporativa e o nível de diclosure: a separação dos papéis de presidente do conselho e presidente executivo melhoraria a qualidade do monitoramento e reduziria os benefícios de detenção informações por parte do executivo principal, havendo assim aumento da qualidade de evidenciação de informações; adicionalmente, a posição do presidente do conselho, em relação a sua independência, poderia influenciar os gestores a divulgar mais informações; a independência do conselho é defendida com o argumento de que conselheiros independentes têm o papel de monitoramento e a 
dominância de conselheiros independentes no conselho poderia proporcionar maior poder para coagir os gestores a divulgar mais informações; a presença de membros familiares no conselho, em países com concentração de propriedade, poderia gerar menor demanda para divulgação de informações, já que os proprietários devem ter mais acesso as informações por fazerem parte da administração; a presença e atuação de conselheiros com formação em contabilidade nos conselhos poderia demonstrar maior influência sobre as políticas de divulgação de empresa, pois eles podem optar por divulgar mais informações para melhorar a imagem corporativa, bem como a credibilidade da equipe gestora. Os resultados apresentados mostram relação negativa entre disclosure e separação de cargos entre presidente executivo e presidente do conselho, resultado contrário ao esperado; e presença de familiares como membros do conselho, resultado de acordo com o esperado, ou seja, empresas apresentam menor nível de disclosure quando têm maior participação de familiares no conselho.

Ho e Wong (2001) também investigaram a relação entre mecanismos de governança corporativa e o nível de evidenciação voluntário. Os mecanismos foram proporção de membros independentes no CA, existência de Comitê de Auditoria, separação entre papéis do presidente executivo e presidente do CA e percentual de membros da família controladora no conselho. Os resultados apresentados pelos autores indicaram associação positiva e significante entre a existência de Comitê de Auditoria e o nível de evidenciação e relação negativa entre o nível de evidenciação e o percentual de membros da família no CA. No trabalho de Felo (2009) também são apresentadas evidencias de relação negativa entre participação de conselheiros internos e nível de evidenciação, já presença de conselheiros independentes com expertise financeira estaria relacionada com melhora na transparência de evidenciação.

O estudo de Beekes e Brown (2006) mostra as seguintes conclusões: empresas australianas melhor governadas apresentam evidenciação mais informativa; apresentam preços mais sensíveis à evidenciação; têm maior cobertura de analistas; e o consenso da previsão de analistas é menos enviesado e mais acurado, como consequência, informações com valor relevante são mais tempestivamente incorporadas aos preços das ações.

Clubb (2006) em uma discussão sobre o estudo mencionado anteriormente conclui que esse estudo traz uma contribuição interessante para a literatura sobre a relação entre as práticas de governança corporativa e a evidenciação financeira ao oferecer suporte para os reguladores do mercado de capitais preocupados com a elevação do fluxo de informações para os 
investidores e implica em diminuição do custo de capital devido ao aperfeiçoamento das práticas de governança corporativa.

Beekes et al. (2007) encontram que empresas canadenses com melhores estruturas de governança comunicam-se com o mercado por meio de mais documentos. Conclui-se que a maneira como uma empresa é governada pode ter impacto na transparência e desempenho da empresa, assim como na prestação de contas aos acionistas.

As evidências sugerem a visão de que a estrutura de governança é um importante fator que poderia influenciar a evidenciação e transparência das empresas. A estrutura de governança poderia também impactar no nível de qualidade da evidenciação das empresas. Portanto, parece que a estrutura de governança representa um papel na operação eficiente dos mercados de capitais (BEEKES et al., 2007). Bushman e Smith (2001) encontram evidências que a divulgação influencia positivamente a governança corporativa, reduzindo os problemas de agência entre acionistas e administradores.

Em sentido amplo, segundo Dantas et al. (2005), para alcançar a transparência sustentada com o disclosure, a empresa deve divulgar informações qualitativas e quantitativas que possibilitem aos usuários formar uma compreensão das atividades desenvolvidas e dos seus riscos, cumprindo aspectos de tempestividade, detalhamento e relevância indispensáveis.

No contexto nacional, a pesquisa de Lanzana (2004) teve como objetivo detectar relação significante entre disclosure e governança por meio de regressões utilizando o método dos Mínimos Quadrados Ordinário no período de 2002. As variáveis de governança utilizadas foram cinco: duas relacionadas à estrutura de propriedade, direito de controle e diferença entre o direito de controle e o direito sobre o fluxo de caixa do acionista controlador; e três relacionadas ao conselho de administração, número de conselheiros, independência e separação de cargos entre o presidente executivo e o presidente do conselho. Os resultados indicaram que uma das variáveis de estrutura de propriedade (diferença entre o direito de controle e o direito sobre o fluxo de caixa do acionista controlador) apresentou efeito de substituição entre nível de disclosure e governança, ou seja, esse mecanismo compensa o nível de disclosure. Já para a variável independência relacionada ao CA foi confirmado o efeito de complementaridade, mostrando que o grau de independência do conselho é relevante para empresas com boas práticas de disclosure. 
Verifica-se, de acordo com a literatura, que a governança corporativa é uma influência significativa na frequência de evidenciação das empresas. De acordo com o exposto, verificase que um maior nível de evidenciação representa uma via de mão dupla, pois beneficia os usuários com as informações de que necessitam para o seu processo decisório, o que reflete na valorização da entidade, aumentando a confiabilidade da organização perante credores, investidores e demais agentes e contribui para o aumento da liquidez de suas ações e a redução do custo de capital.

Dessa forma, percebe-se que o alinhamento do CA às melhores práticas de governança pode ter impacto em diversas atividades desenvolvidas pelos conselhos. Sendo de grande relevância o melhor entendimento de como a adoção de melhores práticas de governança relativas ao CA pode afetar as condições e a dinâmica dos trabalhos do conselho no que concerne ao nível de evidenciação e como isto se desenvolve para contribuir com a efetividade do conselho.

Partindo do conhecimento que os mecanismos de governança continuam evoluindo nas empresas de diversos países desenvolvidos e emergentes e com base nos vários estudos que testam relações diretas entre apenas alguns mecanismos de governança separadamente, verifica-se a necessidade de uma nova abordagem nas pesquisas com a avaliação dos mecanismos de forma agregada e melhorando o nível de entendimento da dinâmica dos conselhos de administração.

Neste estudo aborda-se as variáveis de independência, disponibilidade de tempo e diversidade e comitês para representarem a adoção de melhores práticas de governança relativas ao CA com o intuito de relacioná-las com o nível de evidenciação das empresas, o que em última instância revelaria a efetividade do conselho de administração. Tais relações levariam ao desenvolvimento de ambiente propício para funcionamento efetivo no que concerne à atividade de monitoramento do conselho. Este estudo também explora a presença do profissional da área contábil nos conselhos a fim de averiguar a contribuição desse profissional para o aperfeiçoamento dos debates e diversidade na formação dos conselheiros, o que contribuiria para um ambiente favorável a ações efetivas e melhor nível de evidenciação, assunto ainda não estudado nos estudos expostos.

A decisão de abordar a relação entre a adoção de melhores práticas de governança relativas ao CA e o nível de evidenciação é importante por ser um tema ainda pouco explorado e com 
potencial de contribuir com indicações da relevância de alguns mecanismos de governança como impulsionadores de aperfeiçoamento das estruturas de governança corporativa e do nível de evidenciação adotados pelas empresas. 


\section{PROCEDER METODOLÓGICO}

De acordo com Martins e Theóphilo (2007) a ciência busca captar a realidade e a metodologia é o meio pelo qual esse objetivo pode ser alcançado. O intuito principal da metodologia é o aprimoramento dos procedimentos e parâmetros utilizados nas pesquisas. Para se alcançar tal objetivo é necessário traçar um caminho que guie o trabalho para que o objetivo seja alcançado. Esse caminho é definido como método.

A presente pesquisa se enquadra no enfoque quantitativo, pois utiliza coleta e análise de dados para responder às questões de pesquisa e testar as hipóteses estabelecidas (SAMPIERI et al., 2006). Baseia-se principalmente em medições numéricas e análises estatísticas para estabelecer padrões de comportamento de uma população. Esse enfoque tem como fundamentação a abordagem empírica, que de acordo com Martins e Theóphilo (2007) é vista como uma descrição dos fatos, os quais existem independentemente de atribuições de valor ou posicionamento teórico, permitindo com que sejam induzidas conclusões. No empirismo o requisito para verificação é a aplicação de testes experimentais e mensuração quantitativa das variáveis.

Este estudo fundamenta-se no método indutivo, definido por Marconi e Lakatos (2003) como o processo no qual parte-se de um conjunto de dados particulares e premissas predeterminadas, inferindo conclusões prováveis universais com objetivo de levar a resultados mais amplos.

Em relação ao tipo de pesquisa, esta pesquisa pode ser caracterizada como descritiva e explicativa. Nesse sentido, é descritiva porque busca especificar propriedades e características importantes sobre o fenômeno estudado e oferece a vantagem de possibilitar previsões ou relações iniciais sobre as variáveis envolvidas (SAMPIERI et al., 2006). E, de acordo com Sampieri et al. (2006), a pesquisa explicativa busca investigar detalhadamente as relações entre as variáveis sendo mais estruturadas com objetivo de explorar, descrever e associar as variáveis além de proporcionar um entendimento do fenômeno a que se referem.

Os procedimentos são baseados no método estatístico, que segundo Marconi e Lakatos (2003, p. 108), “[...] significa redução de fenômenos sociológicos, econômicos, políticos etc. a 
termos quantitativos e a manipulação estatística, permitindo comprovar as relações dos fenômenos entre si e obter generalizações sobre sua natureza, ocorrência ou significado." As técnicas de análise utilizadas serão estatísticas descritiva e inferencial com utilização de análise de dados em painel desbalanceado.

De acordo com o resultado, a pesquisa pode ser indicada como aplicada já que as evidências encontradas poderão ser aplicadas futuramente e, segundo Andrade (2003, p. 122), “a pesquisa visa às aplicações práticas, com o objetivo de atender as exigências da vida moderna".

\subsection{Hipóteses}

Como objetivo principal, esta pesquisa visa verificar a relação entre o alinhamento do CA a certas práticas recomendadas de governança e o nível de evidenciação das empresas. $\mathrm{O}$ objetivo específico é avaliar a atuação do profissional com formação na área contábil nos conselhos. Verificando, particularmente, a relevância da diversidade de formação e a associação entre o nível de evidenciação e a participação desses profissionais nos conselhos.

A hipótese levantada, com fundamentação na literatura, suporta a ideia de que a efetividade do conselho pode ser impactada não somente pela composição per se, mas também por outros atributos, relacionados às características individuais dos conselheiros. Considera-se que o nível de evidenciação pode ser influenciado pelo fato da empresa ter um alinhamento do CA com práticas de governança corporativa recomendadas. Esse alinhamento engloba variáveis referentes à independência do conselho, a disponibilidade de tempo, a diversidade do conselho e estrutura de comitês.

Hipótese 1: De acordo com a relação de complementaridade, quanto melhor o alinhamento do CA às práticas de governança recomendadas melhor será o nível de evidenciação das empresas.

Hipótese 2: De acordo com a relação de substituição, quanto pior o alinhamento do CA às práticas de governança recomendadas melhor será o nível de evidenciação das empresas. 
Com base na literatura (LEVRAU; VAN DEN BERGHE, 2007; JOHN; SENBET, 1998; VAN DEN BERGHE; LEVRAU, 2004; NICHOLSON; KIEL, 2004; BEEKES; BROWN, 2006; BEEKES et al., 2007), entende-se que essas relações propiciem um ambiente favorável a efetividade dos conselhos. No entanto, o escopo deste trabalho será o teste das relações descritas nas hipóteses 1 e 2.

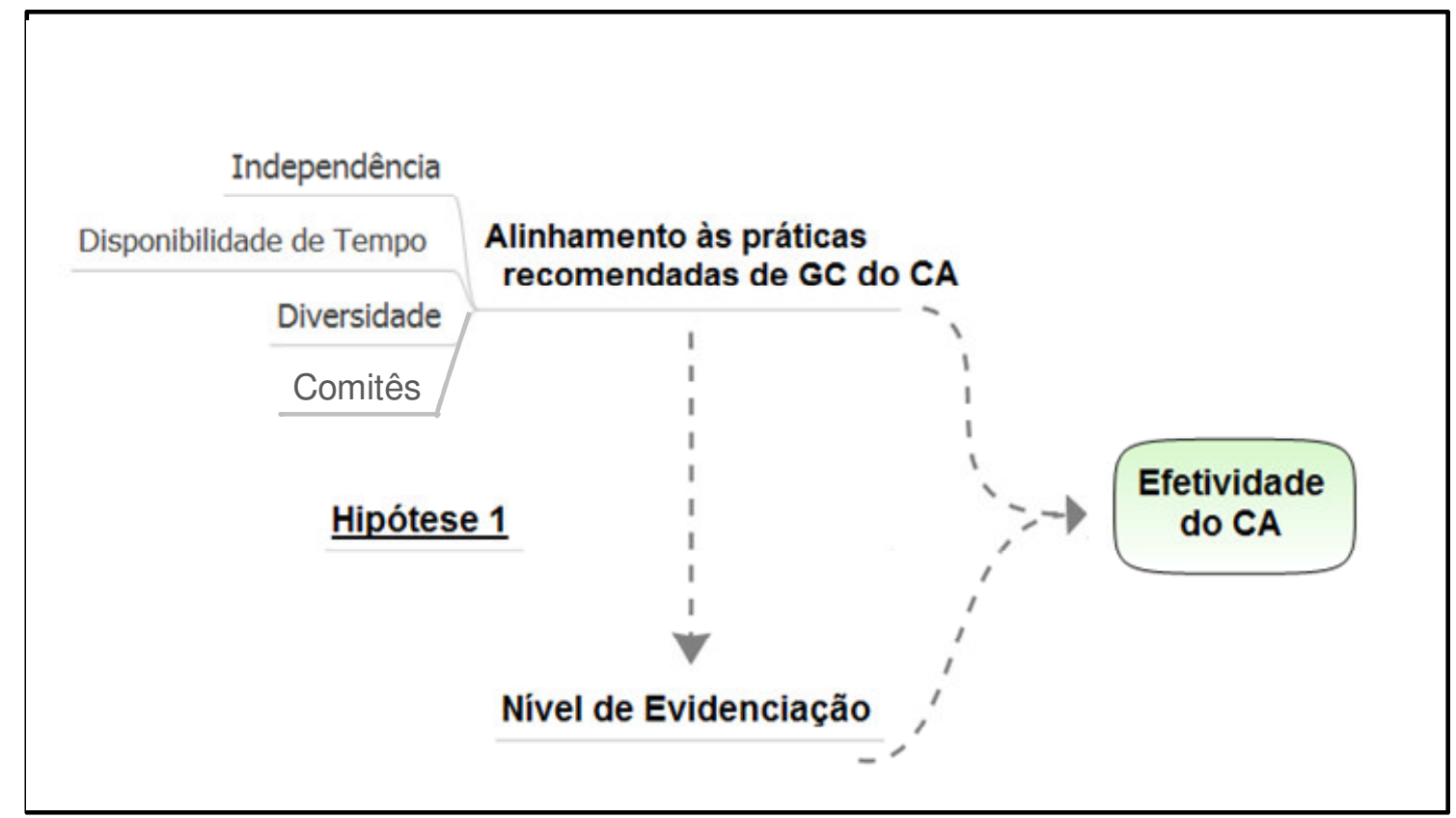

Figura 5 - Diagrama de hipóteses

\subsection{Modelo}

Com o intuito de testar a relação entre o alinhamento do CA às práticas de governança e o nível de evidenciação das empresas os dados foram organizados em painel e os métodos estatísticos aplicados foram: pooling com mínimos quadrados ordinários (MQO), efeitos fixos e efeitos aleatórios.

Para testar a hipótese 1, tem-se o seguinte modelo de pesquisa:

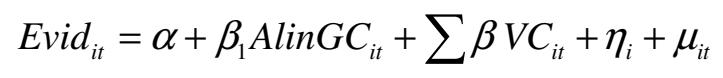

Caso a relação seja de complementaridade, espera-se encontrar relação estatística significante e positiva para o coeficiente $\beta_{1}$. Se a relação for de substituição, espera-se um sinal negativo do referido coeficiente. 
Alin $G C_{i t}$ - índice de alinhamento do CA às práticas recomendadas de Governança Corporativa

$V C_{i t}$ - variáveis de controle, descritas no Quadro 1.

$\eta_{i}+\mu_{i t}$ - termo de erro decomposto, $\eta_{i t}$ capta a heterogeneidade não observada e $\mu_{i t}$ representa o termo de erro do modelo.

No Quadro 1 apresenta-se as variáveis de controle utilizadas na pesquisa: tamanho do CA, tamanho da empresa, negociação de ações da empresa no Novo Mercado ou ADRs 2 ou 3 na Bolsa de Nova Iorque (NYSE), tipo de controle, estrutura de propriedade e setores. As variáveis de controle auxiliam a evitar possíveis problemas de endogeneidade e variáveis omitidas nos estudos empíricos.

Quadro 1- Variáveis de controle
\begin{tabular}{|l|c|c|}
\hline \multicolumn{1}{|c|}{ Variável } & Sigla & Operacionalização \\
\hline Tamanho do CA & TAM_CA & N $^{\circ}$ membros efetivos do CA \\
\hline Tamanho da empresa & TAM & Ln Receita Operacional Líquida \\
\hline ADR23 & ADR2e3 & Dummy 1 para empresas com ADR 2 ou 3 \\
\hline Novo Mercado & NM & Dummy 1 para empresas do Novo Mercado \\
\hline Propriedade & PROP & Ln \% Ações Votantes 3 maiores Acionistas \\
\hline & & Estatal, Compartilhado, Disperso, Familiar, \\
Tipo de Controle & CONTR & Estrangeiro \\
\hline Setor & SET & Classificação Setorial da BM\&FBovespa \\
\hline
\end{tabular}

Como testes de robustez foram analisadas regressões sem as variáveis ADR 2 e 3 e Novo Mercado para verificar se estas variáveis influenciaram os resultados obtidos na relação entre o alinhamento do CA às práticas de governança e o nível de evidenciação. O objetivo foi de verificar se o sentido dos resultados obtidos com o modelo original se mantinha robusto, e dessa forma, fosse possível confirmar o relacionamento com as hipóteses de complementaridade e/ou substituição dos mecanismos de governança com o nível de evidenciação.

\subsection{Tratamento estatístico}

Para a verificação das associações existentes entre o índice de alinhamento do CA às práticas de governança e o nível de evidenciação das empresas foram realizadas inicialmente análises exploratórias envolvendo testes de diferenças de médias e correlação para melhor visualização 
e entendimento dos dados utilizados. Posteriormente, realizou-se análises de regressão com dados em painel, visando examinar relação existente entre o alinhamento do CA às práticas de governança e o nível de evidenciação das empresas.

A análise em painel permite analisar informações de diferentes indivíduos ou empresas, por exemplo, que podem ser acompanhadas em diferentes períodos de tempo. Dados em painel podem ser divididos em painéis balanceados ou não balanceados. Painéis balanceados consistem em informações das mesmas variáveis ao longo do tempo, já em painéis não balanceados as variáveis podem estar presentes em um período e não estar no próximo período, proporcionando uma maior flexibilidade para os dados. Nesta pesquisa utiliza-se painel desbalanceado, já que algumas informações de um ano podem ocasionalmente não estarem disponíveis para o próximo ano.

Os dados em painel, de acordo com Gujarati (2006), apresentam as seguintes vantagens:

Maior número de observações, aumentando os graus de liberdade e a eficiência dos parâmetros;

- Auxilia na redução de problemas de multicolinearidade de variáveis explicativas;

- Apresenta dinâmica intertemporal, ou seja, combina as técnicas de análise por corte transversal e séries temporais;

Em relação ao tipo de abordagem dos dados em painel, citam-se três: efeito pooling, efeito fixo e efeito aleatório. A abordagem do efeito pooling ou $M Q O$, em que tanto o intercepto, quanto a inclinação da reta de regressão servem para todas as empresas, durante todo o período de tempo. Apesar de sua simplicidade, a regressão combinada pode distorcer a verdadeira relação entre as variáveis explicativas e explicadas (GUJARATI, 2006).

Para levar em conta a natureza específica das empresas, tem-se a abordagem dos efeitos fixos, em que os interceptos das empresas podem ser diferentes devido às características especiais de cada empresa. Embora o intercepto possa diferir entre indivíduos, cada intercepto individual é invariante no tempo. Já a abordagem de efeito aleatório considera que os termos de erro podem estar correlacionados ao longo do tempo e ao longo das unidades (GUJARATI, 2006).

Para definir qual abordagem do modelo em painel os dados se adaptam melhor são utilizados alguns testes. Segundo Wooldridge (2006), entre o efeito pooling e o efeitos fixos, o Teste de 
Chow é utilizado. Esse teste também pode ser utilizado para verificar a adequação entre os modelos de efeito pooling e efeito aleatório, além do teste LM de Breusch-Pagan. Para testar o melhor modelo entre o efeito fixo e o efeito aleatório utiliza-se o teste de Hausman, que testa se a correção dos erros é adequada para escolha do efeito aleatório, caso contrário escolhe-se o efeito fixo.

\subsection{Definição teórica e operacional das variáveis}

As variáveis envolvidas na investigação do relacionamento do alinhamento do CA às práticas de governança com o nível de evidenciação estão representadas na Figura 6.

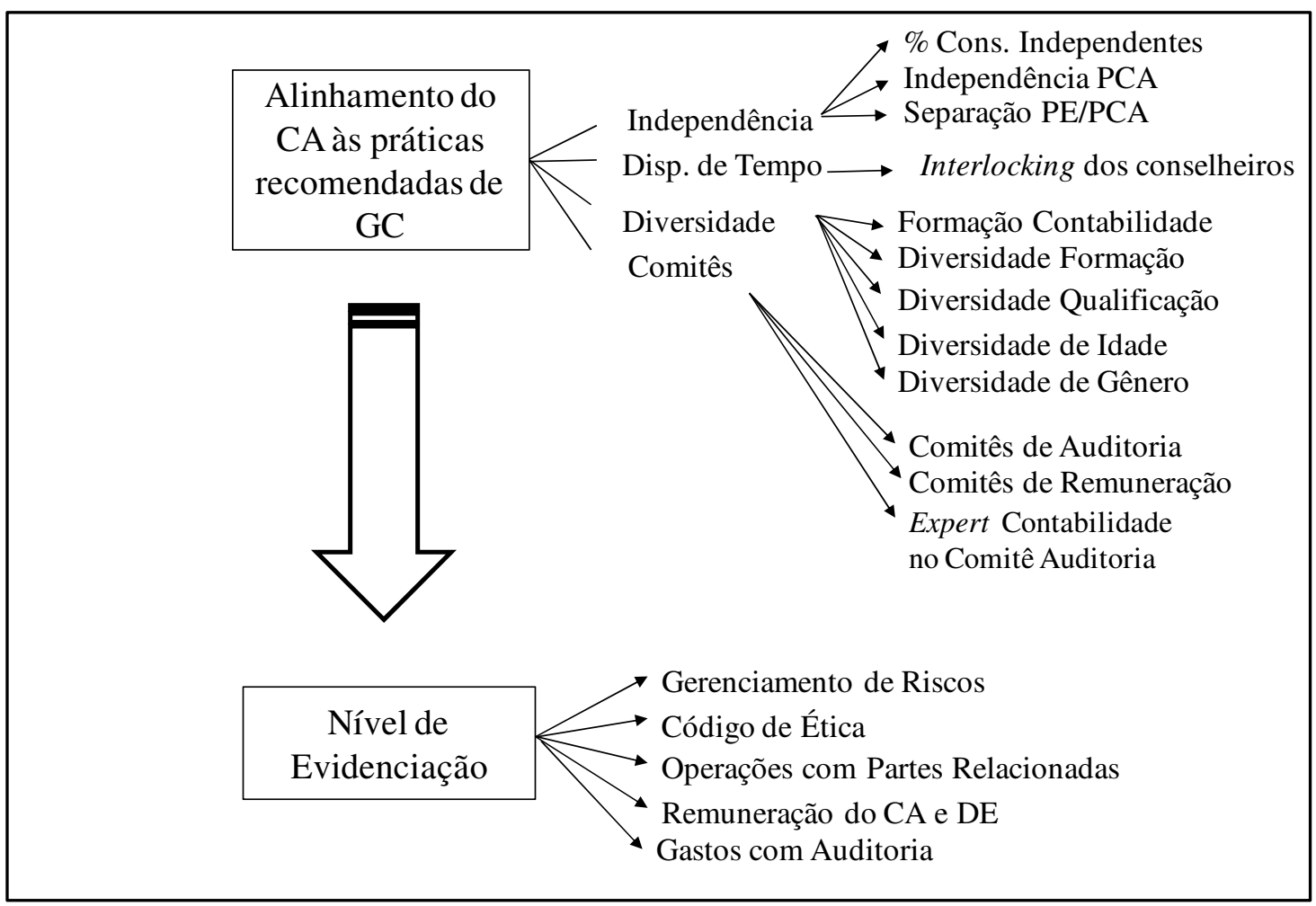

Figura 6 - Composição das variáveis

A verificação do alinhamento do CA às práticas recomendadas de governança foi realizada por meio de análise detalhada das informações dos conselhos e conselheiros em relação a algumas variáveis que compõem este índice. As informações sobre as características individuais dos conselheiros foram verificadas por meio da análise dos currículos e informações sobre os conselheiros disponibilizadas pelas empresas. 
O procedimento utilizado levou em consideração à categorização de cada membro que compõe o conselho de administração das empresas, para assim acessar as variáveis relacionadas ao alinhamento do $\mathrm{CA}$ às práticas recomendadas de governança, que estão divididas em quatro categorias, a saber: independência, disponibilidade de tempo, diversidade e comitês:

\section{Independência}

- Nível de independência do conselho: percentual de conselheiros independentes, independência analisada a luz da definição do IBGC (2009). Esta variável apresenta limitação da classificação de independência de cada conselheiro devido impossibilidade de averiguar cada item da definição de conselheiro independente do IBGC (2009) pela falta de informações disponibilizadas para verificação de vínculos mais detalhados que não são de conhecimento explícito. Os conselheiros foram classificados em 5 categorias, de acordo com classificação utilizado por Saito e Dutra (2002): interno - profissional que participa simultaneamente do conselho e da diretoria da empresa; interno e afiliado profissional que participa da diretoria da empresa e apresenta algum vínculo relacionado na classificação de afiliado; afiliado - profissional que possui uma das seguintes características: (i) ex-funcionário da companhia ou grupo controlador; (ii) funcionário ou beneficiário de fundação previdenciária patrocinada pela própria companhia; (iii) exintegrante do governo ou de companhia estatal que detenha ou participe do controle; (iv) diretor ou conselheiro de empresa controlada ou coligada; e (v) acionistas controladores ou majoritários e/ou seus familiares; externo - profissionais que não puderam ser classificados em qualquer uma das outras categorias; independente - não apresentam nenhum tipo de vínculo explícito, pessoal ou profissional, com a empresa e/ou seus executivos, acionistas controladores ou majoritários e/ou seus familiares;

- Independência do presidente do conselho: presidente do conselho de administração é um membro independente/externo. Os conselheiros foram considerados independentes/externos quando não apresentam nenhum tipo de vínculo explícito com a empresa e/ou seus executivos, acionistas controladores ou majoritários e/ou seus familiares;

- Separação de papéis do presidente executivo e presidente do conselho: ocupação dos cargos por pessoas distintas. 


\section{Disponibilidade de Tempo}

- Interlocking dos conselheiros: participação do conselheiro simultaneamente em outros conselhos de empresas listadas na BM\&FBovespa. O limite utilizado para participação em outros conselhos de cada conselheiro foi de participação em 3 ou mais conselhos, como no trabalho de Santos et al. (2009). Essa métrica está relacionada ao conceito de "busy board", ou seja, presença de uma grande proporção (acima de 50\%) de conselheiros externos que participam em 3 ou mais conselhos de diferentes empresas (FICH; SHIVDASANI, 2004).

\section{Diversidade}

- Formação em contabilidade: conselheiro é formado em curso de graduação ou pósgraduação na área contábil. Essa variável se limita a verificar a formação dos conselheiros e não sua atuação profissional na área;

- Diversidade de formação: verificação da formação educacional dos conselheiros, por exemplo, administração, ciências contábeis, engenharia, economia, direito entre outros. Essa variável se limita a verificar a formação dos conselheiros e não sua atuação profissional na área;

- Diversidade de qualificação: verificação da qualificação educacional, separação entre especialização, mestrado e doutorado;

- Diversidade etária: informação sobre a idade dos conselheiros e classificação em faixas etárias.

- Diversidade de gênero: verificação da presença de homens e mulheres nos conselhos.

\section{Comitês}

- Comitês: existência de comitês vinculados ao conselho e composto por conselheiros, tais como: Comitê de Auditoria e Comitê de Remuneração;

- Experts em contabilidade no Comitê de Auditoria: presença de conselheiros ou membros externos especialistas da área contábil no Comitê de Auditoria;

A mensuração do índice de alinhamento do CA às práticas recomendadas de governança corporativa tem como vantagem o oferecimento de uma reflexão geral da qualidade da governança dentro da empresa no que se referem aos itens abordados, desse modo captura diversos fatores que podem afetar o funcionamento do conselho e o nível de evidenciação. 
Adicionalmente, foi elaborada uma pontuação para o nível de evidenciação de políticas adotadas pelas empresas baseado nas informações adicionais e voluntárias disponibilizadas pelas empresas no que concerne:

- Gerenciamento de riscos: divulgação da política de gerenciamento de riscos nas demonstrações financeiras ou website da empresa.

- Código de ética: existência de código de ética disponível no website da empresa.

- Operações com partes relacionadas: divulgação de política clara de operações com partes relacionadas nas demonstrações financeiras ou website da empresa.

- Remuneração dos administradores: divulgação do sistema de remuneração dos administradores com separação entre conselho de administração (CA) e diretoria executiva (DE) nas demonstrações financeiras ou website da empresa.

- Gastos com auditoria: divulgação dos gastos com auditoria nas demonstrações financeiras ou website da empresa.

As justificativas para as variáveis envolvidas neste estudo da relação entre o alinhamento do CA às práticas recomendadas de governança e o nível de evidenciação das empresas estão demonstradas no Quadro 2. A racionalização operacional das variáveis da pesquisa assim como as siglas utilizadas para tais variáveis estão expostas no Quadro 3. 
Quadro 2 - Variáveis e justificativas

\begin{tabular}{|c|c|c|c|}
\hline \multicolumn{3}{|c|}{ Variável } & Justificativa \\
\hline \multirow{11}{*}{$\begin{array}{l}\text { Alinhamento do } \\
\text { CA às Práticas } \\
\text { Recomendadas de } \\
\text { GC }\end{array}$} & \multirow{3}{*}{ Independência } & $\%$ Conselheiros Independentes & $\begin{array}{l}\text { Devido à ausência de vínculos estreitos com a empresa, } \\
\text { conselheiros independentes são capazes e melhor } \\
\text { posicionados ao abordar questões de certa distância e } \\
\text { manifestar-se livremente (LEVRAU; VAN DEN } \\
\text { BERGHE, 2007). }\end{array}$ \\
\hline & & Independência PCA ${ }^{1}$ & $\begin{array}{l}\text { Importância do presidente do conselho de administração ser } \\
\text { independente para a criação de condições para a efetividade } \\
\text { dos conselheiros independentes (ROBERTS et al. , 2005). }\end{array}$ \\
\hline & & Separação PE $/ \mathrm{PCA}$ & $\begin{array}{l}\text { Separando esses papéis há diluição do poder do presidente } \\
\text { executivo e redução do potencial de dominação dos } \\
\text { executivos no conselho (VAN DEN BERGHE; LEVRAU, } \\
\text { 2004). }\end{array}$ \\
\hline & $\begin{array}{c}\text { Disponibilidade de } \\
\text { Tempo }\end{array}$ & Interlocking & $\begin{array}{l}\text { O monitoramento dos executivos requer esforço e tempo. } \\
\text { Com o aumento das atividades adicionais dos conselheiros } \\
\text { há também aumento da demanda de tempo e o esforço } \\
\text { diminui o montante de atenção que os conselheiros podem } \\
\text { devotar para monitorar a empresa (MORCK } \text { et al. }, 1998 \text { ). }\end{array}$ \\
\hline & \multirow{5}{*}{ Diversidade } & Formação em Contabilidade & $\begin{array}{l}\text { Membros do conselho devem ter um mínimo conhecimento } \\
\text { de contabilidade, direito e do setor (VAN DEN BERGHE; } \\
\text { LEVRAU, 2004). Os conhecimentos especificos em } \\
\text { contabilidade auxiliam na diversidade do conselho } \\
\text { contribuindo para o enriquecimento dos debates para tomada } \\
\text { de decisão e melhoram o nível de evidenciação. }\end{array}$ \\
\hline & & Diversidade de Formação & $\begin{array}{l}\text { Reflete diferenças de conhecimento, experiências e } \\
\text { habilidades (devido a formação educacional, profissional e } \\
\text { experiências em setores e negócios) (LEVRAU; VAN } \\
\text { DEN BERGHE, 2007). }\end{array}$ \\
\hline & & Diversidade de Qualificação & $\begin{array}{l}\text { Reflete diferenças de conhecimento, experiências e } \\
\text { habilidades (devido a formação educacional, profissional e } \\
\text { experiências em setores e negócios) (LEVRAU; VAN } \\
\text { DEN BERGHE, 2007). }\end{array}$ \\
\hline & & Diversidade de Idade & $\begin{array}{l}\text { Diversidade etária com o intuito de encorajar as diferentes } \\
\text { perspectivas de grupos etários diversos, como parte } \\
\text { integrante do plano sucessório (KANG et al, 2007). }\end{array}$ \\
\hline & & Diversidade de Gênero & $\begin{array}{l}\text { Mulheres não fazem parte da rede social masculina, o que } \\
\text { permite a elas serem mais independentes (KANG et al, } \\
\text { 2007). }\end{array}$ \\
\hline & \multirow{2}{*}{ Comitês } & Comitês (Auditoria, Remuneração) & $\begin{array}{l}\text { As estruturas administrativas internas do conselho também } \\
\text { podem afetar a efetividade do conselho (JOHN; SENBET, } \\
\text { 1998). }\end{array}$ \\
\hline & & $\begin{array}{l}\text { Expert em Contabilidade no Com. } \\
\text { Auditoria }\end{array}$ & $\begin{array}{l}\text { O requisito de ter ao menos um expert em finanças no } \\
\text { comitê de auditoria está baseado na idéia de melhora na } \\
\text { efetividade de monitoramento (HE et al, 2008). }\end{array}$ \\
\hline \multirow{5}{*}{\multicolumn{2}{|c|}{ Nivel de Evidenciação }} & Gerenciamento de Riscos & \multirow{5}{*}{$\begin{array}{l}\text { A estrutura de governança corporativa deve assegurar } \\
\text { divulgação oportuna e precisa de todos os fatos relevantes } \\
\text { referentes à empresa (OCDE, 2004). Um método para } \\
\text { mitigar o problema de agência é reduzir a assimetria } \\
\text { informacional entre executivos e acionistas (DONNELLY; } \\
\text { MULCAHY, 2008). }\end{array}$} \\
\hline & & Código de Ética & \\
\hline & & Operações Partes Relacionadas & \\
\hline & & Remuneração & \\
\hline & & Gastos com Auditoria & \\
\hline
\end{tabular}

\footnotetext{
${ }^{1}$ PCA - Presidente do Conselho de Administração
}

${ }^{2} \mathrm{PE}$ - Presidente Executivo 
Quadro 3 - Operacionalização das variáveis

\begin{tabular}{|c|c|c|c|c|c|c|}
\hline \multicolumn{3}{|c|}{ Variável } & \multicolumn{2}{|c|}{ Operacionalização } & \begin{tabular}{|c|} 
Critérios \\
.
\end{tabular} & \multirow{2}{*}{$\begin{array}{c}\text { Sigla } \\
\text { IND_CA }\end{array}$} \\
\hline \multirow{11}{*}{$\begin{array}{l}\text { Alinhamento do CA às } \\
\text { Práticas Recomendadas de } \\
\text { GC (AlinGC) }\end{array}$} & \multirow{3}{*}{ Independência } & $\%$ Conselheiros Independentes & \multirow{11}{*}{$\begin{array}{c}\text { Índice de alinhamento do CA às } \\
\text { práticas recomendadas de GC, } \\
\text { pontuação de } 0 \text { a } 16 .\end{array}$} & \multirow{3}{*}{$\begin{array}{c}\text { Subíndice de independência, pontuação de } 0 \\
\text { a } 5 .\end{array}$} & $\begin{array}{|ll|}3 \text { para conselhos com } 50 \% \text { ou mais de independência, } & 2 \\
\text { para conselhos entre } 49,9 \% \text { e } 30 \% \text { de independência, } & 1 \\
\text { para conselhos entre } 29,9 \% \text { e } 20 \% \text { de independência, } & 0 \\
\text { para conselhos com menos de } 20 \% \text { de independência. } & \\
\end{array}$ & \\
\hline & & \begin{tabular}{|l|} 
Independência PCA ${ }^{1}$ \\
1 PCA - Presidente do Conselho de Administração
\end{tabular} & & & $\begin{array}{c}1 \text { PCA membro independente/externo, 0 PCA não é membro } \\
\text { independente/externo. }\end{array}$ & IND_PCA \\
\hline & & Separação $\mathrm{PE}^{2} / \mathrm{PCA}{ }^{2} \mathrm{PE}$ - Presidente Executivo & & & $\begin{array}{l}1 \text { PE/PCA são pessoas diferentes, } 0 \text { PE/PCA são mesma } \\
\text { pessoa. }\end{array}$ & SEP \\
\hline & Disponibilidade de Tempo & Interlocking dos conselheiros & & $\begin{array}{l}\text { Subíndice de disponibilidade de tempo, } \\
\text { pontuação de } 0 \text { a } 1 .\end{array}$ & $\begin{array}{c}1 \text { para conselhos com } 2 \text { ou menos conselheiros com } \\
\text { interlocking, } 0 \text { para conselhos com } 3 \text { ou mais conselheiros com } \\
\text { interlocking. }\end{array}$ & DISP_T \\
\hline & \multirow{5}{*}{ Diversidade } & Formação em Contabilidade & & \multirow{5}{*}{$\begin{array}{c}\text { Subíndice de diversidade, pontuação de } 0 \text { a } \\
7 .\end{array}$} & $\begin{array}{c}1 \text { ao menos um conselheiro com formação na área contábil, } 0 \\
\text { nenhum conselheiro com formação na área contábil. }\end{array}$ & CONT \\
\hline & & Diversidade de Formação & & & \begin{tabular}{|c|}
2 para conselhos com muita diversidade (mais de 6 formações \\
diferentes), 1 para conselhos com diversidade mediana (entre 3 \\
e 5 formações diferentes), 0 para conselhos com pouca \\
diversidade de formação (entre 2 e 1 formações diferentes). \\
\end{tabular} & DIV_FORM \\
\hline & & Diversidade de Qualificação & & & $\begin{array}{l}2 \text { para conselhos com algum conselheiro com mestrado ou } \\
\text { doutorado, } 1 \text { para conselhos com algum conselheiro com } \\
\text { especialização, } 0 \text { para conselhos com nenhum desses títulos. }\end{array}$ & DIV_QUAL \\
\hline & & Diversidade de Idade & & & $\begin{array}{l}1 \text { para conselhos com diversidade (com } 3 \text { ou mais faixas } \\
\text { etárias), } 0 \text { para conselhos com pouca diversidade (com } 2 \text { ou } \\
\text { menos faixas etárias). }\end{array}$ & DIV_IDA \\
\hline & & Diversidade de Gênero & & & $\begin{array}{l}1 \text { para conselhos com diversificação de gênero (ao menos } 1 \\
\text { conselheira), } 0 \text { para conselhos sem diversificação de gênero. }\end{array}$ & DIV_GEN \\
\hline & \multirow[b]{2}{*}{ Comitês } & Comitês (Auditoria, Remuneração) & & \multirow[b]{2}{*}{ Subíndice de comitês, pontuação de 0 a 3 . } & $\begin{array}{c}1 \text { para cada comitê vinculado ao conselho e composto por } \\
\text { conselheiros (Auditoria, Remuneração). }\end{array}$ & \multirow[b]{2}{*}{ COM_CA } \\
\hline & & $\begin{array}{l}\text { Expert em Contabilidade no Com. } \\
\text { Auditoria }\end{array}$ & & & $\begin{array}{c}1 \text { ao menos um conselheiro com formação na área contábil no } \\
\text { Comitê de Adutoria, } 0 \text { nenhum conselheiro com formação na } \\
\text { área contábil. }\end{array}$ & \\
\hline \multirow{5}{*}{\multicolumn{2}{|c|}{ Nivel de Evidenciação (Evid) }} & Gerenciamento de Riscos & \multirow{5}{*}{\multicolumn{2}{|c|}{ Índice do nível de evidenciação, pontuação de 0 a 6 . }} & $\begin{array}{l}1 \text { Políica de gerenciamento de riscos disponível, } 0 \text { Polifica de } \\
\text { gerenciamento de riscos não disponível. }\end{array}$ & \multirow{5}{*}{ EVID } \\
\hline & & Código de Ética & & & 1 Código de Ética disponível, 0 Código de Ética não disponível. & \\
\hline & & Operações Partes Relacionadas & & & \begin{tabular}{|l|} 
1 Política de operações com partes relacionadas disponível, 0 \\
Política de operações com partes relacionadas não disponível. \\
\end{tabular} & \\
\hline & & $\begin{array}{l}\text { Remuneração do CA e } \mathrm{DE}^{3} \\
\text { 3 DE - Diretoria Executiva }\end{array}$ & & & $\begin{array}{c}\text { Política de remuneração do CA e DE disponível, } 1 \text { Política de } \\
\text { remuneração do CA ou DE disponível, } 0 \text { Politica de } \\
\text { remuneração não disponível. }\end{array}$ & \\
\hline & & Gastos com Auditoria & & & $\begin{array}{c}\text { Gastos com auditoria disponível, } 0 \text { Gastos com auditoria não } \\
\text { disponível. }\end{array}$ & \\
\hline
\end{tabular}




\subsection{População, Amostra e Período}

A população da pesquisa é composta pelas empresas negociadas na BM\&FBovespa, se tratando de 449 empresas em 2007 e 438 em 2008 (BM\&FBOVESPA, 2009).

As amostras utilizadas nesta pesquisa derivam do estudo realizado pela KPMG e CEG “A Governança Corporativa e o Mercado de Capitais", a qual se encontra no segundo ano de realização. Tal estudo aborda questões relacionadas aos seguintes temas: Conselho de Administração, comitês do Conselho, Conselho Fiscal, Código de Ética e Conduta, Auditorias Interna e Independente, Gestão de Riscos, Política de Dividendos, Transações com Partes Relacionadas, e Controle Acionário.

O estudo da KPMG e CEG (2008) utilizou em 2007 duas amostras: a) a primeira composta pelas empresas listadas no Novo Mercado da Bovespa - 100 empresas b) a segunda composta por empresas de uma amostra aleatória extraída das empresas negociadas no mercado tradicional da BM\&FBovespa - 100 empresas. Já para a amostra de 2008, houve alteração do critério de amostragem no estudo da KPMG e CEG (2009), passando a utilizar três amostras: a) a primeira composta pelas empresas listadas no Novo Mercado da BM\&FBovespa - 100 empresas b) a segunda composta pelas empresas listadas no segmento diferenciado de governança Nível 1 e Nível 2 - 57 empresas; e, c) a terceira composta por empresas de uma amostra aleatória extraída das empresas negociadas no mercado tradicional da Bovespa - 50 empresas.

Para as amostras do mercado tradicional da BM\&FBovespa o tipo de amostragem utilizada é a aleatória simples, ou seja, cada empresa selecionada do mercado tradicional da BM\&FBovespa possui a possibilidade de ser escolhida (SAMPIERI et al., 2006), nas outras duas amostras toda a população do Novo Mercado e Nível 1 e 2 foi analisada para o período de 2008, já no período de 2007 foi analisada toda a população do Novo Mercado.

O período analisado é o de 2007 e 2008 e a amostra para cada ano contempla 172 e 202 empresas, respectivamente, após a verificação de disponibilidade das informações necessárias. Totalizando 374 observações para o período de dois anos. 
A seleção de três amostras diferenciadas tem como racional a comparação entre as empresas que aderiram voluntariamente aos segmentos diferenciados de governança corporativa da BM\&FBovespa, porém com níveis de requisitos diferentes como do Novo Mercado e Nível 1 e 2, além das empresas representativas do mercado tradicional da BM\&FBovespa com o intuito de evitar erro de seleção da amostra e aumentar a amostragem pesquisada.

\subsection{Fontes de coleta de dados}

As variáveis foram coletadas por meio de informações disponíveis publicamente, como no Relatório de Informações Anuais - IAN e nos relatórios anuais das empresas disponíveis em seus websites. Alguns dados para as variáveis de controle foram coletados no software Economática. De posse desses dados foram elaborados os índices que compõem as principais variáveis a serem testadas nos modelos especificados.

\subsection{Limitações}

Os estudos empíricos estão sujeitos a algumas limitações em relação aos métodos econométricos utilizados. Algumas limitações podem ser mitigadas com a utilização de diferentes tratamentos estatísticos. A seguir são apresentadas as possíveis barreiras encontradas e algumas soluções para superar as limitações desta pesquisa.

Um dos limitadores é o problema de endogeneidade dos regressores, isso ocorre quando há correlação entre as variáveis explicativas e o termo de erro do modelo empírico utilizado. Caso a premissa de não existência de correlação seja inválida considera-se que as variáveis explicativas são endógenas, o que levará a inconsistência nos estimadores resultantes (BARROS, 2009). Para mitigar tal problema utilizam-se variáveis instrumentais, mas devido à dificuldade de encontrar instrumentos válidos esse problema pode ser contornado de certa forma com a utilização de dados em painel. 
Esta pesquisa está sujeita a algumas causas relativas ao problema de endogeneidade, entre elas: causalidade reversa, variáveis ausentes e erros de mensuração. A causalidade reversa ocorre em casos em que ambas as variáveis podem ser consideradas independentes e dependentes uma em relação à outra (BARROS, 2009). Esse problema pode distorcer as relações, devido à possibilidade de haver um caminho de mão dupla nas relações, ou seja, o alinhamento do CA às práticas de governança pode influenciar o nível de evidenciação, mas também o contrário pode acontecer. Com a utilização de dados em painel é possível mitigar esse problema.

No que concerne às variáveis ausentes, esse fato decorre da não consideração de variáveis importantes no modelo, consequentemente, os estimadores podem ser enviesados. Com o intuito de atenuar esse problema são utilizadas variáveis de controle nos modelos testados, além da decomposição do erro do modelo, na qual há o termo $\eta_{i t}$ o qual capta a heterogeneidade não observada. A utilização desses mecanismos, segundo Barros (2009), pode auxiliar no controle ou eliminação deste problema.

Esta pesquisa também está sujeito ao erro de mensuração das variáveis, que depende diretamente da qualidade dos dados disponibilizados pelas empresas, pois as variáveis se baseiam nessas informações para a composição dos índices que serão utilizados nos modelos especificados. A variável de independência dos conselhos apresenta limitação da classificação de independência de cada conselheiro devido impossibilidade de averiguar cada item da definição de conselheiro independente do IBGC (2009) podendo levar a erro de mensuração na variável pela falta de informações disponibilizadas para verificação de vínculos mais detalhados que não são de conhecimento explícito. Devido ao exposto, é necessária cautela ao analisar esses dados. Caso as variáveis independentes apresentem erro de mensuração o regressor terá coeficiente atenuado (WOOLDRIDGE, 2007).

Outro limitador se refere às definições propostas para as variáveis, as definições propostas têm como base estudos anteriores que utilizaram as mesmas variáveis. No entanto, algumas podem ser questionáveis, como a independência do conselheiro, tornando-se complexo capturar a essência qualitativa da independência de cada conselheiro. A classificação utilizada nesta pesquisa teve como base a definição de independência do Código do IBGC (2009), porém apenas com as informações que publicamente são disponibilizadas pelas empresas nos currículos dos conselheiros não 
foi possível averiguar cada item da definição de conselheiro independente, podendo existir vínculos que não são de conhecimento explícito e, dessa forma, a classificação de independência poderia ser subestimada ou superestimada.

A última limitação se refere à escolha da utilização de índices como variáveis para verificação das relações. Tanto a variável dependente (nível de evidenciação), quanto a variável independente (alinhamento do CA às práticas recomendadas de governança) foram mensuradas por meio da elaboração de índices de pontuação, o que remete ao problema de censura nas variáveis. Em outras palavras, há delimitação nos intervalos de pontuação com censura no termo zero e intervalo finito, o que pode comprometer o uso de algumas técnicas de regressão. Segundo Wooldridge (2007), ao trabalhar essas variáveis com mínimos quadrados ordinários haverá inconsistência dos parâmetros, esse problema poderá ser solucionado com a utilização de estimação por máxima verossimilhança com o modelo Tobit. 


\section{ANÁLISE DE RESULTADOS}

\subsection{Amostra pesquisada}

A amostra de empresas utilizada nesta pesquisa está demonstrada na Figura 7. A amostra foi constituída por 200 empresas de 2007 e 207 empresas de 2008, das quais 172 e 202 empresas foram consideradas com informações completas para as análises descritivas e 307 com observações finais para as análises de regressão.

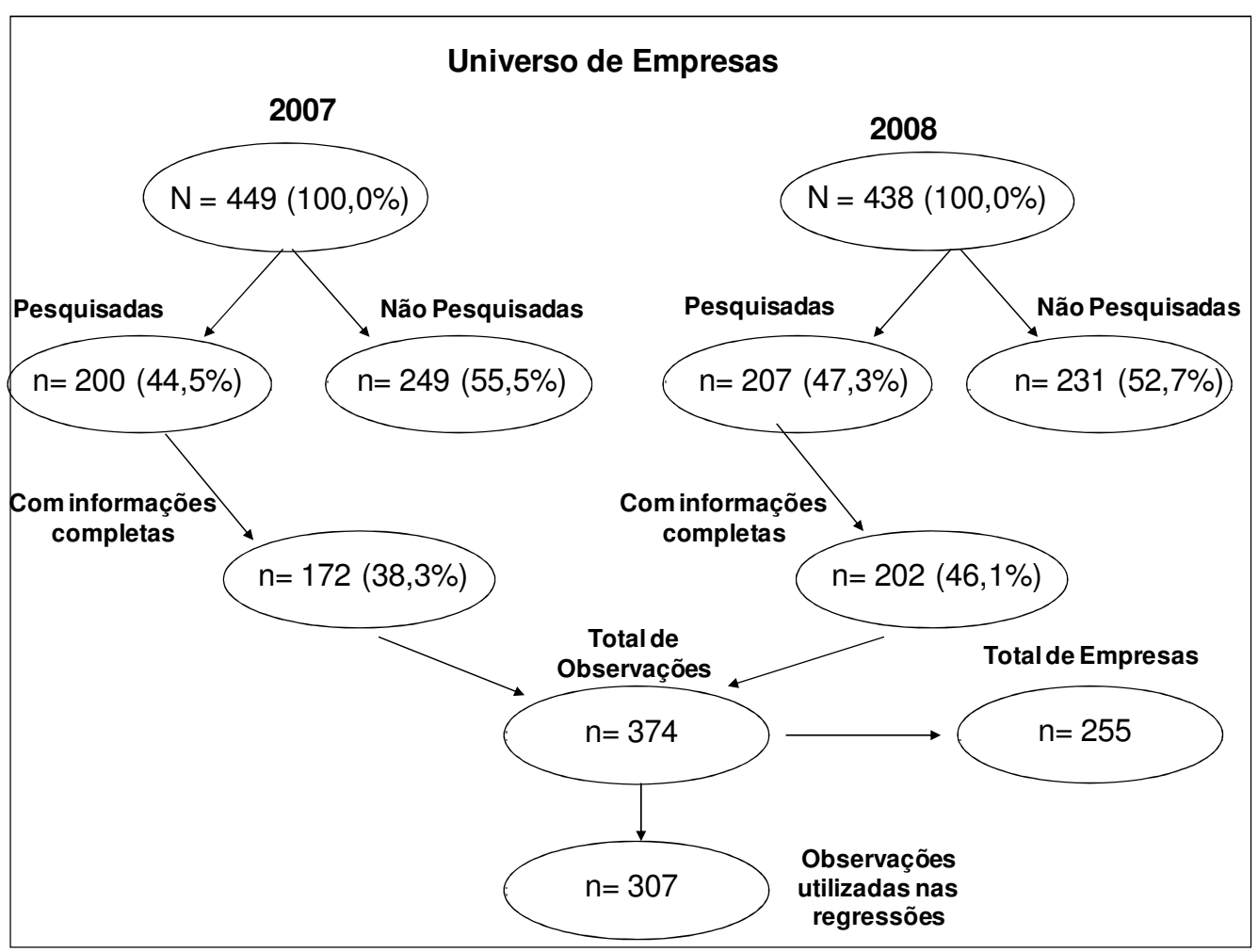

Figura 7 - Amostra de empresas pesquisadas

\subsection{Estatísticas descritivas}

$\mathrm{Na}$ Tabela 1 encontra-se a representação das empresas da amostra por estrutura de controle. Observa-se predominância de empresas com controle familiar (53.5\%) em 2007, enquanto que em 2008 a amostra apresenta 37.6\% de empresas com controle compartilhado e $34.2 \%$ de empresas com controle familiar. Esta classificação será utilizada para verificação de diferenças em relação às médias dos índices de 
alinhamento de governança, assim como, para os subíndices de independência, disponibilidade de tempo, diversidade e comitês, e também para o índice de evidenciação.

Tabela 1- Empresas por tipo de estrutura de controle

\begin{tabular}{lcccc}
\hline & $\begin{array}{c}\mathbf{N}^{\mathbf{0}} \text { empresas } \\
\mathbf{2 0 0 7}\end{array}$ & $\mathbf{\%}$ & $\begin{array}{c}\mathbf{N}^{\mathbf{0}} \text { empresas } \\
\mathbf{2 0 0 8}\end{array}$ & $\mathbf{\%}$ \\
\hline Compartilhado & 38 & $22.1 \%$ & 76 & $37.6 \%$ \\
Disperso & 13 & $7.6 \%$ & 19 & $9.4 \%$ \\
Estatal & 12 & $7.0 \%$ & 15 & $7.4 \%$ \\
Estrangeiro & 17 & $9.9 \%$ & 23 & $11.4 \%$ \\
Familiar & 92 & $53.5 \%$ & 69 & $34.2 \%$ \\
Total & $\mathbf{1 7 2}$ & $\mathbf{1 0 0 . 0 \%}$ & $\mathbf{2 0 2}$ & $\mathbf{1 0 0 . 0 \%}$ \\
\hline
\end{tabular}

A amostra da pesquisa apresenta preponderância de empresas com adoção de práticas de governança, 62\% das empresas em 2007 e 63\% em 2008 estavam listadas no segmento Novo Mercado da BM\&FBovespa e/ou na Bolsa de Nova Iorque (ADR 2 e 3), ambos com maiores exigências em relação as práticas de governança corporativa. No entanto, a amostra também apresenta diversificação, visto que 32\% das empresas em 2007 e $17 \%$ em 2008 tinham negociação no segmento Tradicional da BM\&FBovespa.
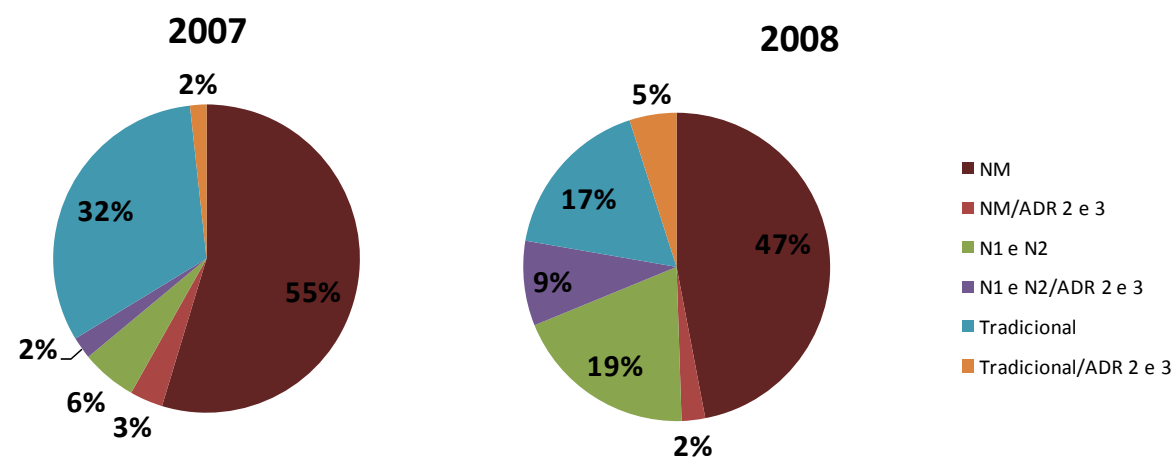

\section{Gráfico 1 - Distribuição das 255 empresas por diferentes segmentos de listagem}

As empresas analisadas estão distribuídas em 10 setores principais de acordo com a classificação da BM\&FBovespa. Na Tabela 2, verifica-se heterogeneidade na representação setorial, com a maioria das companhias no setor de Construção e Transporte $(20.3 \%, 2007 ; 18.8 \%, 2008)$, seguida pelo setor Financeiro com percentual de 16.90 em 2007 e 16.3 em 2008. 
Tabela 2 - Estatística descritiva dos setores

\begin{tabular}{lcccc}
\hline \multicolumn{1}{c}{ Setor } & $\begin{array}{c}\mathbf{N}^{\mathbf{0}} \text { empresas } \\
\mathbf{2 0 0 7}\end{array}$ & $\mathbf{\%}$ & $\begin{array}{c}\mathbf{N}^{\mathbf{0}} \text { empresas } \\
\mathbf{2 0 0 8}\end{array}$ & $\mathbf{\%}$ \\
\hline Bens Industriais & 23 & $13.4 \%$ & 27 & $13.4 \%$ \\
Construção e Transporte & 35 & $20.3 \%$ & 38 & $18.8 \%$ \\
Consumo Cíclico & 11 & $6.4 \%$ & 16 & $7.9 \%$ \\
Consumo não Cíclico & 24 & $14.0 \%$ & 26 & $12.9 \%$ \\
Financeiro e Outros & 29 & $16.9 \%$ & 33 & $16.3 \%$ \\
Materiais Básicos & 18 & $10.5 \%$ & 23 & $11.4 \%$ \\
Petróleo, Gás e Biocombustíveis & 4 & $2.3 \%$ & 3 & $1.5 \%$ \\
Tecnologia da Informação & 6 & $3.5 \%$ & 5 & $2.5 \%$ \\
Telecomunicações & 8 & $4.7 \%$ & 10 & $5.0 \%$ \\
Utilidade Pública & 14 & $8.1 \%$ & 21 & $10.4 \%$ \\
Total & $\mathbf{1 7 2}$ & $\mathbf{1 0 0 . 0 \%}$ & $\mathbf{2 0 2}$ & $\mathbf{1 0 0 . 0 \%}$ \\
\hline
\end{tabular}

Em relação às características dos conselhos, observa-se que a média de conselheiros nas empresas da amostra é 6.8 em 2007 e 7.7 em 2008 (Tabela 3). A maioria dos conselhos $(63.4 \%, 2007 ; 75.7 \%, 2008)$ segue a recomendação de composição do conselho com 5 a 9 membros indicada no código do IBGC (2004). Considerando a $4^{\mathrm{a}}$ edição do código do IBGC de 2009, o percentual passa a ser de 69.3 (2007) e 87.6 (2008) de empresas que seguem a recomendação de composição com mínimo de 5 e máximo de 11 conselheiros.

Evidencia-se similaridade nos resultados encontrados por Black et al. (2008) com média de 7.88 membros utilizando uma amostra de 88 empresas brasileiras. Mas continua diferente dos patamares de outros países, Reino Unido (8.3 membros), Suíça (9.8 membros), Bélgica (12.9 membros) (HEIDRICK \& STRUGGLES, 2007) e Estados Unidos 10.8 membros (SPENCER STUART, 2009).

Estes resultados podem ter relação com a falta de comitês para assessoramento dos conselhos na estrutura de governança das empresas brasileiras, fazendo com que os conselhos brasileiros apresentem tamanhos menores em comparação com outros países. Assim que as estruturas das empresas brasileiras passarem a ter mais comitês para assessorar os conselhos, a composição dos conselhos poderá sofrer alterações convergindo para um aumento na composição. 
Tabela 3 - Estatística descritiva tamanho dos conselhos

\begin{tabular}{lcccc}
\hline Tamanho do conselho & $\begin{array}{c}\text { No empresas } \\
\mathbf{2 0 0 7}\end{array}$ & $\mathbf{\%}$ & $\begin{array}{c}\mathbf{N}^{\mathbf{0}} \text { empresas } \\
\mathbf{2 0 0 8}\end{array}$ & $\boldsymbol{\%}$ \\
\hline De 3 a 4 membros & 26 & $12.9 \%$ & 10 & $5.0 \%$ \\
De 5 a 9 membros & 128 & $63.4 \%$ & 153 & $75.7 \%$ \\
De 10 a 11 membros & 12 & $5.9 \%$ & 24 & $11.9 \%$ \\
Mais de 11 membros & 6 & $3.0 \%$ & 15 & $7.4 \%$ \\
\hline Média & 6.8 & & 7.7 & \\
Desvio Padrão & 2.6 & & 2.5 & \\
Mínimo & 3 & & 3 & \\
Máximo & 17 & & 17 & \\
\hline
\end{tabular}

No total foram analisadas 1169 posições de conselheiros em 2007 e 1549 em 2008 das empresas da amostra, essas posições representam, respectivamente, $35.6 \%$ do total de posições de conselheiros do universo de empresas listadas na BM\&FBovespa em 2007 e $50.3 \%$ em 2008.

Na Tabela 4 apresenta-se a distribuição de acordo com a classificação dos conselheiros. Em primeira classificação, entre conselheiros internos e externos, 1002 posições em 2007 (85.7\%), estavam ocupadas por conselheiros externos. No entanto $35.1 \%$ dos conselheiros foram classificados como afiliados, ou seja, tinham algum dos seguintes vínculos: i) ex-funcionário da companhia ou grupo controlador; (ii) funcionário ou beneficiário de fundação previdenciária patrocinada pela própria companhia; (iii) exintegrante do governo ou de companhia estatal que detenha ou participe do controle; (iv) diretor ou conselheiro de empresa controlada ou coligada; e (v) acionistas controladores ou majoritários e/ou seus familiares (SAITO; DUTRA, 2002). Em 2008, os conselheiros externos representavam $87.3 \%$, porém o percentual de afiliados se manteve em 35.6\%. Esses resultados evidenciam que os conselhos das empresas analisadas estão formados preponderantemente por pessoas que têm alguma ligação com a empresa ou sócio controlador/majoritário.

Evidencia-se, adicionalmente, que os conselhos continuam não tendo maioria de independentes como recomendado pelo IBGC (2009). Em 2007 os conselheiros independentes, que não apresentavam vínculo aparente com a empresa ou grupo de controle, representavam $34.6 \%$ e em 2008, ainda menor, em 25.4\%. Estas evidências são corroboradas por resultados de outros estudos nacionais (SAITO; DUTRA, 2002; BLACK et al., 2008). 
Os resultados do Anuário de Governança Corporativa também evidenciam média de $30.4 \%$ de conselheiros independentes nas 97 empresas de capital aberto brasileiras da amostra deste estudo (CAPITAL ABERTO, 2009). Contudo, esses resultados diferem dos encontrados em países europeus (HEIDRICK \& STRUGGLES, 2007), nos quais mostram que $57 \%$ dos conselhos são compostos por conselheiros independentes.

Tabela 4 - Posições ocupadas pelos conselheiros

\begin{tabular}{lcccc}
\hline & $\begin{array}{c}\mathbf{N}^{\mathbf{0}} \\
\text { conselheiros } \\
\mathbf{2 0 0 7}\end{array}$ & $\mathbf{\%}$ & $\begin{array}{c}\mathbf{N}^{\mathbf{0}} \text { conselheiros } \\
\mathbf{2 0 0 8}\end{array}$ & $\mathbf{\%}$ \\
\hline Total de conselheiros nas empresas da amostra & 1169 & & 1549 \\
Independência & & & & \\
Posições ocupadas por Internos & $\mathbf{1 6 7}$ & $\mathbf{1 4 . 3 \%}$ & $\mathbf{1 9 6}$ & $\mathbf{1 2 . 7 \%}$ \\
$\quad$ Internos & 86 & $7.4 \%$ & 102 & $6.6 \%$ \\
$\quad$ Internos e Afiliados* & 81 & $6.9 \%$ & 94 & $6.1 \%$ \\
Posições ocupadas por Externos & $\mathbf{1 0 0 2}$ & $\mathbf{8 5 . 7 \%}$ & $\mathbf{1 3 5 3}$ & $\mathbf{8 7 . 3 \%}$ \\
$\quad$ Afiliados* & 410 & $35.1 \%$ & 551 & $35.6 \%$ \\
$\quad$ Externos & 187 & $16.0 \%$ & 409 & $26.4 \%$ \\
$\quad$ Independentes & 405 & $34.6 \%$ & 393 & $25.4 \%$ \\
\hline
\end{tabular}

*Afiliados - profissional que possui uma das seguintes características: (i) ex-funcionário da companhia ou grupo controlador; (ii) funcionário ou beneficiário de fundação previdenciária patrocinada pela própria companhia; (iii) ex-integrante do governo ou de companhia estatal que detenha ou participe do controle; (iv) diretor ou conselheiro de empresa controlada ou coligada; e (v) acionistas controladores ou majoritários e/ou seus familiares.

Ao analisar o percentual de conselheiros independentes em cada empresa em relação ao tamanho de cada conselho, observa-se que $24.4 \%$ das empresas apresentam maioria de independentes no conselho em 2007 e 16.3\% em 2008. Porém estes percentuais devem ser analisados com cautela, pois foram considerados independentes conselheiros que não apresentam vínculos explícitos com a empresa ou grupo de controle. Como essa classificação é complexa, o percentual identificado de conselheiros independentes reflete de forma apenas aproximada e possivelmente superestimada a composição dessa categoria de conselheiros.

Tabela 5 - Nível de independência dos conselhos

\begin{tabular}{lcccc}
\hline & $\begin{array}{c}\mathbf{N}^{\mathbf{0}} \\
\text { empresas } \\
\mathbf{2 0 0 7}\end{array}$ & $\mathbf{\%}$ & $\begin{array}{c}\mathbf{N}^{\mathbf{0}} \\
\text { empresas } \\
\mathbf{2 0 0 8}\end{array}$ & $\mathbf{\%}$ \\
\hline Acima de 50\% de conselheiros independentes & 42 & $24.4 \%$ & 33 & $16.3 \%$ \\
Entre 30\% e 49,9\% de conselheiros independentes & 46 & $26.7 \%$ & 46 & $22.8 \%$ \\
Entre 20\% e 29,9\% de conselheiros independentes & 43 & $25.0 \%$ & 39 & $19.3 \%$ \\
Abaixo de 19,9\% de conselheiros independentes & 41 & $23.8 \%$ & 84 & $41.6 \%$ \\
\hline Média de conselheiros independentes & 2.4 & & 2.0 \\
Desvio Padrão & 1.6 & \multicolumn{3}{c}{1.7} \\
Mínimo & 0 & \multicolumn{3}{c}{0} \\
Máximo & 7 & & \\
\hline
\end{tabular}


Ainda há muitas empresas com percentual inferior a $20 \%$ de conselheiros independentes (41.6\%, 2008). A média de independência dos conselhos brasileiros é relativamente baixa ao ser comparada com a média de independência dos conselhos de outros países europeus como Reino Unido em que 91\% dos conselhos apresentam maioria de independentes; Itália com 52\%; Espanha com 40\%, segundo a pesquisa de Heidrick \& Sruggles (2007), na qual as amostras são compostas pelas maiores empresas dos países segundo a capitalização de mercado. Já nos Estados Unidos, o percentual de independência dos conselhos é de 82\% nas empresas do índice S\&P 500 (SPENCER STUART, 2009).

A questão da independência dos conselhos é importante, pois, de acordo com trabalhos teóricos baseados na teoria de agência, conselheiros independentes são monitores mais efetivos, que mantém certa distância da gestão das empresas e não estão sujeitos a dominância por parte do presidente executivo, podendo fazer questionamentos imparciais que auxiliam no processo de tomada de decisão do conselho (TIROLE, 2006; ROBERTS et al., 2005; LEVRAU; VAN DEN BERGHE, 2007).

No que se refere à classificação do presidente do conselho, Guerra (2009) destaca uma questão crítica às boas práticas de governança corporativa no que tange ao grau de concentração de poder no cargo de presidente do conselho, que é a separação entre os papéis de presidente do conselho e controladores. Contrário ao recomendado, o presidente do conselho na maior parte dos casos deste referido estudo também era familiar do acionista controlador ou o próprio controlador.

Apesar de haver separação entre os cargos de presidente executivo e presidente do conselho na maioria das empresas em ambos os anos $(69.2 \%, 2007 ; 74.8 \%, 2008) \mathrm{em}$ linha com estudos anteriores (KPMG; CEG, 2008; BLACK et al., 2008), evidencia-se o fato de haver uma potencial concentração de poder do presidente do conselho nos resultados deste estudo (Tabela 6). A potencial concentração de poder dos controladores por meio do cargo de presidente do conselho fica evidente, pois 63.7\% (2007) e 64.9\% (2008) dos presidentes dos conselhos das empresas apresentam algum vínculo familiar ou de relação profissional com o grupo controlador, sendo assim classificados como conselheiros afiliados. Este fato pode sugerir dominância dos controladores tendo em vista que a ocupação de vagas do conselho por pessoas com vínculos facilitaria o exercício do poder de controle por parte dos acionistas majoritários e/ ou controladores. 
Poucas são as empresas que têm seus presidentes dos conselhos como membros externos e/ou independentes $(23.7 \%, 2007 ; 33.8 \%, 2008)$.

Tabela 6 - Separação cargos PE $^{1}$ e PCA ${ }^{2}$

\begin{tabular}{lcccc}
\hline & $\begin{array}{c}\mathbf{N}^{\mathbf{0}} \text { empresas } \\
\mathbf{2 0 0 7}\end{array}$ & $\mathbf{\%}$ & $\begin{array}{c}\mathbf{N}^{\mathbf{0}} \\
\text { empresas } \\
\mathbf{2 0 0 8}\end{array}$ & $\mathbf{\%}$ \\
\hline Pessoas distintas nos cargos & 119 & $69.2 \%$ & 151 & $74.8 \%$ \\
Pessoas iguais nos cargos & 48 & $27.9 \%$ & 47 & $23.3 \%$ \\
PCA não informado & 5 & $2.9 \%$ & 4 & $2.0 \%$ \\
\hline PCA interno & 11 & $8.1 \%$ & 8 & $5.4 \%$ \\
PCA interno/afiliado & 38 & $28.1 \%$ & 44 & $29.7 \%$ \\
PCA afiliado & 86 & $63.7 \%$ & 96 & $64.9 \%$ \\
PCA externo & 32 & $23.7 \%$ & 50 & $33.8 \%$ \\
PCA não informado & 5 & $3.7 \%$ & 4 & $2.7 \%$ \\
\hline${ }^{1}$ PE - Presidente Executivo & & & &
\end{tabular}

Em relação a proxy para disponibilidade de tempo mensurada com base no conceito de busy board, os resultados são apresentados na Tabela 7. Grande parte das empresas analisadas apresentam conselhos com 3 ou mais conselheiros interconectados (interlocking), o percentual chega a $48.8 \%$ em 2007 e $47.5 \%$ em 2008. Os resultados corroboram as evidências de Santos et al. (2009), os autores demonstram que cerca de 68\% dos conselhos em 2005 tinham algum conselheiro com participação em outro CA, nesta pesquisa esse percentual é de $83.2 \%$ para o ano de 2008. Conselheiros com participação em outros CAs apresentariam menor disponibilidade de tempo para se prepararem com a dedicação necessária às atividades de cada conselho, fato que poderia prejudicar as decisões tomadas por esses conselhos.

Tabela 7 - Disponibilidade de tempo - Conselhos que têm conselheiros com participação em outro CA

\begin{tabular}{|c|c|c|c|c|}
\hline & $\begin{array}{c}\mathbf{N}^{\mathbf{0}} \\
\text { empresas } \\
2007 \\
\end{array}$ & $\%$ & $\begin{array}{c}\mathrm{N}^{\circ} \\
\text { empresas } \\
2008 \\
\end{array}$ & $\%$ \\
\hline Total de empresas da amostra & 172 & & 202 & \\
\hline \multicolumn{5}{|l|}{ Disponibilidade de tempo } \\
\hline Nenhum conselheiro com participação em outros CAs & 37 & $21.5 \%$ & 34 & $16.8 \%$ \\
\hline 1 ou 2 conselheiros com participação em outros CAs & 51 & $29.7 \%$ & 72 & $35.6 \%$ \\
\hline 3 a 5 conselheiros com participação em outros CAs & 65 & $37.8 \%$ & 75 & $37.1 \%$ \\
\hline 6 ou mais conselheiros com participação em outros CAs & 19 & $11.0 \%$ & 21 & $10.4 \%$ \\
\hline
\end{tabular}

Os resultados referentes à diversidade de formação e qualificação estão apresentados nas Tabelas 8 a 10. Nas tabelas 8 e 9 apresentam-se as formações mais comuns entre os conselheiros, sendo Engenharia, Administração, Economia e Direito em ambos os anos. A maioria das empresas em 2007 e 2008 (88.9\%; 91.5\%) apresenta conselheiros com formação em Engenharia, representados por 373 e 503 conselheiros respectivamente. 
Na sequência está o curso de Administração, em que 132 empresas em 2007 e 160 empresas em 2008 têm ao menos um conselheiro com tal graduação.

Estes resultados vão ao encontro de evidências de outros estudos nacionais (MENDESDA-SILVA et al., 2007) que analisaram as formações dos conselheiros em dois dos principais setores industriais brasileiros (Alimentos \& Bebidas e Energia Elétrica) em 2004 e encontraram predominância de conselheiros com formação em Engenharia $(35,9 \%)$.

Tabela 8 - Diversidade de formação dos conselheiros - 2007

\begin{tabular}{|c|c|c|c|}
\hline & $\begin{array}{c}\mathrm{N}^{\circ} \text { empresas } \\
2007\end{array}$ & $\mathbf{N}^{0}$ conselheiros & $\%$ \\
\hline Total de conselheiros nas em & amostra & 1169 & \\
\hline \multicolumn{4}{|l|}{ Formação* } \\
\hline Administração & 132 & 284 & $24.3 \%$ \\
\hline Ciências Contábeis & 40 & 47 & $4.0 \%$ \\
\hline Direito & 100 & 170 & $14.5 \%$ \\
\hline Economia & 125 & 228 & $19.5 \%$ \\
\hline Engenharia & 153 & 373 & $31.9 \%$ \\
\hline Medicina & 8 & 14 & $1.2 \%$ \\
\hline Outros - Área de Biológicas & 13 & 15 & $1.3 \%$ \\
\hline Outros - Área de Exatas & 23 & 26 & $2.2 \%$ \\
\hline Outros - Área de Humanas & 47 & 64 & $5.5 \%$ \\
\hline Não disponível** & & 116 & $9.9 \%$ \\
\hline
\end{tabular}

Tabela 9 - Diversidade de formação dos conselheiros - 2008

\begin{tabular}{lccc} 
& $\begin{array}{c}\mathbf{N}^{\mathbf{0}} \text { empresas } \\
\mathbf{2 0 0 8}\end{array}$ & $\mathbf{N}^{\mathbf{0}}$ conselheiros & \% \\
\hline Total de conselheiros nas empresas da amostra & 1549 & \\
Formação* & & & \\
Administração & 160 & 366 & $31.3 \%$ \\
Ciências Contábeis & 53 & 61 & $5.2 \%$ \\
Direito & 120 & 213 & $18.2 \%$ \\
Economia & 155 & 316 & $27.0 \%$ \\
Engenharia & 185 & 503 & $43.0 \%$ \\
Medicina & 11 & 17 & $1.5 \%$ \\
Outros - Área de Biológicas & 19 & 22 & $1.9 \%$ \\
Outros - Área de Exatas & 35 & 44 & $3.8 \%$ \\
Outros - Área de Humanas & 58 & 84 & $7.2 \%$ \\
Não disponível** & 1 & 130 & $11.1 \%$ \\
\hline *Alguns conselheiros têm mais de uma formação. & & \\
**Informação não disponível para ao menos um conselheiro. & &
\end{tabular}

Os profissionais da área contábil estão presentes em 40 empresas em 2007 e 53 em 2008. Essas empresas são representadas por apenas 47 conselheiros com formação na área contábil, em 2007, com aumento para 61 conselheiros com esta formação em 2008, 
respectivamente uma proporção de apenas $4.0 \%$ e 5.2\%. Evidencia-se participação ainda incipiente da classe contábil na composição dos conselhos.

No que concerne à qualificação dos conselheiros, verifica-se que a maioria das empresas da amostra de 2007 (82.5\%) e 2008 (86.1\%) apresenta, na composição do conselho, conselheiros com algum título de especialização. Não obstante, conselheiros com mestrado e doutorado representam somente $22.4 \%$ (2007) e $29.9 \%$ (2008), das posições que possuem alguma titulação além da graduação. Estes resultados estão de acordo com as evidências de pouca presença de acadêmicos nos conselhos reportado por Black et al. (2008). A maioria dos conselheiros possui ao menos uma formação de nível superior. Não estavam disponíveis informações de 116 e 130 conselheiros em 2007 e 2008, respectivamente.

Tabela 10 - Diversidade de qualificação dos conselheiros

\begin{tabular}{|c|c|c|c|c|c|c|}
\hline & $\begin{array}{l}N^{o} \text { empresas } \\
2007\end{array}$ & $\begin{array}{l}\mathbf{N}^{\mathbf{o}} \\
\text { conselheiros }\end{array}$ & $\%$ & $\begin{array}{l}N^{\circ} \text { empresas } \\
2008\end{array}$ & $\begin{array}{l}\mathbf{N}^{\mathbf{o}} \\
\text { conselheiros }\end{array}$ & $\%$ \\
\hline \multicolumn{7}{|c|}{$\begin{array}{l}\text { Total de conselheiros nas empresas da } \\
\text { amostra }\end{array}$} \\
\hline \multicolumn{7}{|l|}{ Qualificação* } \\
\hline Graduação & 172 & 1053 & $90.1 \%$ & 202 & 1419 & $121.4 \%$ \\
\hline Especialização & 142 & 382 & $32.7 \%$ & 174 & 487 & $41.7 \%$ \\
\hline Mestrado & 98 & 170 & $14.5 \%$ & 135 & 248 & $21.2 \%$ \\
\hline Doutorado & 62 & 92 & $7.9 \%$ & 76 & 102 & $8.7 \%$ \\
\hline Não Disponível & - & 116 & $9.9 \%$ & 1 & 130 & $11.1 \%$ \\
\hline
\end{tabular}

*Alguns conselheiros têm mais de uma qualificação.

Adicionalmente, verificou-se o nível de diversidade de formação em cada conselho (Tabela 11), ou seja, cada empresa foi classificada em uma condição de diversificação presente no conselho de acordo com o número de membros com formações diferenciadas. A maior parte das empresas tanto em 2007 (125 empresas) quanto em 2008 (167 empresas) apresentam diversidade moderada, com membros do conselho formados em 3 a 5 diferentes graduações. Tal diversidade de experiências supostamente aprimora os debates no conselho segundo Eisenhardt et al., (1997) proporcionando diferentes perspectivas de diversas áreas de formação e, assim, melhorando as discussões sobre assuntos da alçada dos conselhos.

Com a diversificação de formações nos conselhos brasileiros, os resultados corroboram a ideia de Van Den Berghe e Levrau (2004), o conselho deve ser composto por uma 
mistura de pessoas com diferentes personalidades e níveis educacionais, profissionais e de conhecimento, para fomentar o debate e melhores resultados na tomada de decisão.

\begin{tabular}{lccccc} 
Tabela 11 - Diversidade de formação nos conselhos & & & \\
\hline & $\begin{array}{c}\mathbf{N}^{\mathbf{0}} \\
\text { empresas } \\
\mathbf{2 0 0 7}\end{array}$ & $\%$ & $\begin{array}{c}\mathbf{N}^{\mathbf{0}} \\
\text { empresas } \\
\mathbf{2 0 0 8}\end{array}$ & $\mathbf{\%}$ \\
\hline Pouca diversidade (1 ou 2 formações) & 37 & $21.5 \%$ & 23 & $11.4 \%$ \\
Diversidade mediana (3 a 5 formações) & 125 & $72.7 \%$ & 167 & $83.1 \%$ \\
Muita diversidade (6 formações ou mais) & 10 & $5.8 \%$ & 11 & $5.5 \%$ \\
Não disponível & - & & 1 & $0.5 \%$ \\
\hline
\end{tabular}

A diversidade de gênero e de idade é apresentada na Tabela 12. Das posições de conselheiros $94.4 \%$ são ocupadas por homens em ambos os anos pesquisados, verificase clara predominância masculina nos conselhos. Resultados similares foram apresentados no Anuário de Governança (CAPITAL ABERTO, 2009), com amostra de 97 empresas com maior liquidez na BM\&FBovespa, em que a proporção de homens nos conselhos reportada por esta pesquisa foi de $87.4 \%$, demonstrando predominância masculina nos conselhos.

A falta de diversidade de gênero é evidente, as mulheres representam apenas 5.6\% nos conselhos da amostra de empresas brasileiras, percentual muito inferior quando comparado com outros países, como Suécia com 21.0\%, Reino Unido com 15.2\%, Estados Unidos 17.0\%, mas ainda superior a Portugal com apenas 1.0\% (HEIDRICK \& STRUGGLES, 2007; SPENCER STUART, 2009).

Devido à falta de divulgação da idade dos conselheiros nos currículos, as informações sobre idade foram coletadas para 66.0\% (2007) e 64.6\% (2008) dos conselheiros, representados por 771 pessoas em 2007 e 1001 em 2008. Observa-se que há relativa diversidade etária nos conselhos. Os conselheiros estão distribuídos entre 6 faixas etárias, a maior parte dos conselheiros está na faixa etária acima de 51 anos $(47.3 \%$. 2007; 43.6\%, 2008) corroborando com o trabalho de Heidrick \& Struggles (2007) que aponta a necessidade de maior profundidade de experiência levada ao conselho por conselheiros acima de 50 anos, os quais apresentam mais maturidade para tratar dos assuntos de alta gestão que são alvo de decisões e para executar o papel de monitoramento dos conselhos. Semelhantes resultados foram reportados no Anuário de Governança em que os conselhos apresentaram idade média de 50.8 anos (CAPITAL ABERTO, 2009). 
Tabela 12 - Diversidade gênero e idade dos conselheiros

\begin{tabular}{lcccc}
\hline & $\begin{array}{c}\mathbf{N}^{\mathbf{0}} \text { conselheiros } \\
\mathbf{2 0 0 7}\end{array}$ & $\mathbf{\%}$ & $\begin{array}{c}\mathbf{N}^{\mathbf{0}} \text { conselheiros } \\
\mathbf{2 0 0 8}\end{array}$ & $\mathbf{\%}$ \\
\hline $\begin{array}{l}\text { Total de conselheiros nas empresas da } \\
\text { amostra }\end{array}$ & 1169 & & 1549 \\
Gênero & & & & \\
Posições ocupadas por homens & 1104 & $94.4 \%$ & 1463 & $94.4 \%$ \\
Posições ocupadas por mulheres & 65 & $5.6 \%$ & 86 & $5.6 \%$ \\
Idade & & & & \\
$N^{o}$ de conselheiros cuja idade não é divulgada & 398 & $34.0 \%$ & 548 & $35.4 \%$ \\
Abaixo de 30 anos & 7 & $0.6 \%$ & 7 & $0.5 \%$ \\
Entre 31 e 40 anos & 66 & $5.6 \%$ & 82 & $5.3 \%$ \\
Entre 41 e 50 anos & 187 & $16.0 \%$ & 237 & $15.3 \%$ \\
Entre 51 e 60 anos & 239 & $20.4 \%$ & 275 & $17.8 \%$ \\
Entre 61 e 70 anos & 210 & $18.0 \%$ & 296 & $19.1 \%$ \\
Maior que 70 anos & 62 & $5.3 \%$ & 104 & $6.7 \%$ \\
\hline
\end{tabular}

$\mathrm{Na}$ Tabela 13 fica evidente a presença de poucas conselheiras nos conselhos, apenas 65 mulheres (86 mulheres) em 48 empresas (63 empresas) em 2007 (2008). Das empresas analisadas, 124 (2007) e 139 (2008) não possuem mulheres em seus conselhos. Em $19.8 \%$ (2007) e $21.8 \%$ (2008) da amostra há somente uma mulher no conselho e em apenas $8.2 \%$ (2007) e 9.4\% (2008) dos conselhos são compostos com 2 ou mais representantes do sexo feminino. E em apenas 5 empresas em 2007 e 6 empresas em 2008 o cargo de presidente do conselho é ocupado por conselheira.

Apesar da elevação do número de mulheres que participam em conselhos nos diferentes anos, as evidências corroboram com o argumento de Kang et al. (2007) sobre o suposto limite do avanço profissional imposto sobre mulheres (glass ceiling), ou seja, barreira invisível que impede as mulheres e as minorias de avançar no mundo empresarial. Diferentemente dos resultados apresentados, a pesquisa da Catalyst (2005), com base nas 500 empresas da Fortune nos Estados Unidos, reporta que 90\% destas companhias têm ao menos uma conselheira e $14.7 \%$ das posições de conselheiros são ocupadas por mulheres.

Tabela 13 - Presença de conselheiras nos conselhos

\begin{tabular}{lcccc}
\hline & $\begin{array}{c}\mathbf{N}^{\mathbf{0}} \text { empresas } \\
\mathbf{2 0 0 7}\end{array}$ & $\mathbf{\%}$ & $\begin{array}{c}\mathbf{N}^{\mathbf{0}} \text { empresas } \\
\mathbf{2 0 0 8}\end{array}$ & $\mathbf{\%}$ \\
\hline Nenhuma conselheira & 124 & $72.1 \%$ & 139 & $68.8 \%$ \\
1 conselheira & 34 & $19.8 \%$ & 44 & $21.8 \%$ \\
2 conselheiras & 12 & $7.0 \%$ & 17 & $8.4 \%$ \\
3 ou mais conselheiras & 2 & $1.2 \%$ & 2 & $1.0 \%$ \\
Total & 172 & & 202 & \\
\hline Média & 0.38 & & 0.43 & \\
Desvio Padrão & 0.64 & & 0.68 & \\
Mínimo & 0 & & 0 & \\
Máximo & 4 & & 5 & \\
\hline
\end{tabular}


A amplitude etária também é um indicador importante de diversidade no conselho. Dentre as faixas etárias identificadas na pesquisa, 20.4\% (2007) e 17.8\% (2008) dos conselheiros (Tabela 12) estão entre 51 e 60 anos, isso ocorre devido ao fato dessas pessoas apresentarem vasta experiência em diversos cargos ao longo de suas carreiras e estarem disponíveis para serem membros de conselhos (KANG et al., 2007), utilizando seus conhecimentos e experiências para aprimorar as discussões e tomadas de decisão nos conselhos.

Algumas empresas não divulgam a idade de todos os conselheiros $(15.7 \%, 2007 ; 9.9 \%$, 2008), dentre as empresas que divulgam esta informação verificou-se em quantas faixas etárias se enquadravam os conselheiros. Os resultados estão apresentados na Tabela 14 e mostram que as empresas $(33.7 \%, 2007 ; 31.7 \%$, 2008) têm conselheiros em 3 faixas etárias e 20.9\% (2007) e 26.7\% (2008) em 4 faixas etárias, evidenciando a diversidade etárias na maior parte dos conselhos. Porém, observa-se ainda são poucos os conselheiros com idade inferior aos 40 anos $(6.2 \%, 2007 ; 5.8 \%, 2008)$, confirmando os achados de Kang et al. (2007, p. 196) "[...] maioria dos membros do conselho é bem formado, maduro, com experiência, e consequentemente, de meia-idade.”.

Tabela 14 - Diversidade etária nos conselhos

\begin{tabular}{lcccc}
\hline \multicolumn{1}{c}{ Idade dos conselheiros } & $\begin{array}{c}\mathbf{N}^{\mathbf{0}} \text { empresas } \\
\mathbf{2 0 0 7}\end{array}$ & $\mathbf{\%}$ & $\begin{array}{c}\text { No empresas } \\
\mathbf{2 0 0 8}\end{array}$ & $\%$ \\
\hline Não disponível & 27 & $15.7 \%$ & 20 & $9.9 \%$ \\
Em de 1 faixa etária & 20 & $11.6 \%$ & 33 & $16.3 \%$ \\
Em de 2 faixas etárias & 29 & $16.9 \%$ & 26 & $12.9 \%$ \\
Em de 3 faixas etárias & 58 & $33.7 \%$ & 64 & $31.7 \%$ \\
Em de 4 faixas etárias & 36 & $20.9 \%$ & 54 & $26.7 \%$ \\
Em de 5 faixas etárias & 2 & $1.2 \%$ & 5 & $2.5 \%$ \\
Total & 172 & $100.0 \%$ & 202 & $100.0 \%$ \\
\hline
\end{tabular}

\subsection{Análise exploratória}

Foram realizadas análises exploratórias para verificar as associações entre as variáveis analisadas neste estudo. Primeiramente, explorou-se as diferenças de médias das principais variáveis "nível de evidenciação" e "alinhamento às práticas de governança" entre alguns grupos, tais como, empresas que estão sujeitas a regras mais rígidas de governança (Novo Mercado e ADR 2 e 3) e empresas classificadas em diferentes tipos de controle. Na sequência, investigou-se as correlações entre o nível de evidenciação e o 
alinhamento às práticas de governança, assim como a associação com as outras variáveis explicativas.

Com o intuito de verificar se há diferença estatística entre as médias dos índices e subíndices separados por determinados grupos, primeiramente foi realizado o teste Barlett, o qual testa a igualdade das variâncias. Para os grupos que apresentaram variâncias iguais utilizou-se o teste $\mathrm{T}$ para verificar as diferenças entre médias dos índices e subíndices. Quando as variâncias se apresentavam diferentes utilizou-se o teste $\mathrm{T}$ com a aproximação de Welch. Assumiu-se nível de significância de $5 \%$ e foram utilizados testes paramétricos, assumindo-se normalidade dos dados. Segundo Brooks (2008), em amostras suficientemente grandes segue-se o teorema do limite central, no qual as médias das amostras convergem para uma distribuição normal.

\subsubsection{Testes de diferença de médias - Índice de Alinhamento de governança Corporativa}

Com o intuito de investigar se empresas que são negociadas em segmento com regras mais rígidas de governança (Novo Mercado e ADR 2 e 3) e com diferentes tipos de controle apresentam diferenças estatisticamente significantes em relação ao alinhamento às práticas recomendadas de governança corporativa e seus respectivos subíndices (nível de independência, disponibilidade de tempo, diversidade e comitês) apresenta-se a seguir os resultados dos testes de diferenças de médias.

De acordo com a Tabela 15, verifica-se que há diferença significativa, ao nível de significância de 5\%, entre o índice de alinhamento às práticas de governança corporativa nas empresas listadas no segmento Novo Mercado da BM\&FBovespa e empresas com negociação de ADR 2 e 3 na Bolsa de Nova Iorque. Apesar da obviedade dos resultados, fica evidenciado que empresas listadas no Novo Mercado apresentam índice de alinhamento às práticas de governança superior se comparado com empresas dos outros segmentos da BM\&FBovespa. Da mesma maneira, apresentam índice

superior as empresas com negociação nos Estados Unidos, as quais estão sujeitas a normas mais rígidas da SEC (Securities and Exchange Comission). 
Tabela 15 - Teste de diferença de média - Nível de Alinhamento de GC

Teste de diferença de médias entre empresas listadas em segmentos com mais exigências de governança (Novo Mercado e ADR 2 e 3) e tipos de controle de propriedade em relação ao índice de alinhamento às práticas de governança composto pelos subíndices de independência, disponibilidade de tempo, diversidade e comitês.Pontuação máxima 16 pontos.

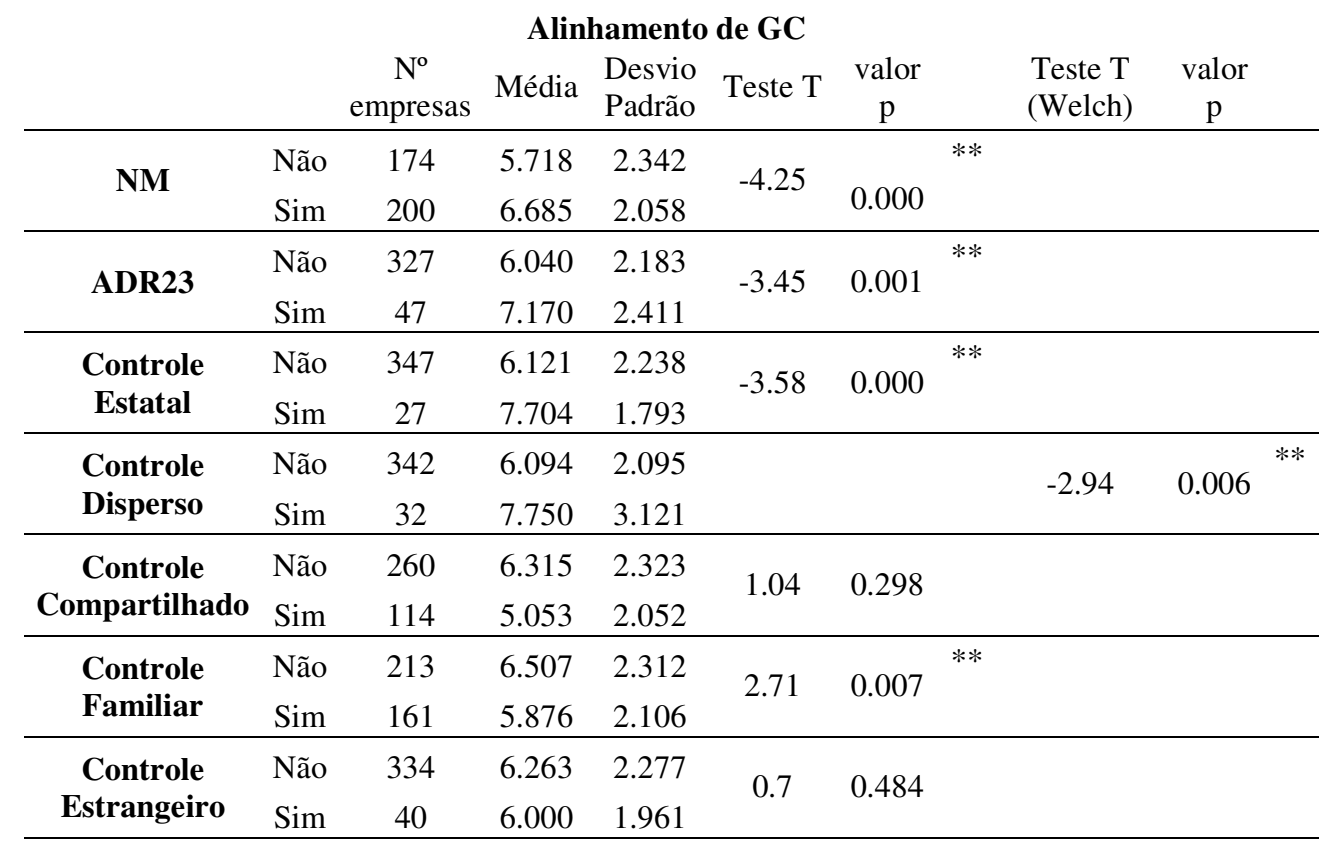

** Nível de significância 5\%

Em relação às diferenças entre os tipos de controle (Tabela 15), empresas com controle estatal e com controle disperso apresentam índices superiores de alinhamento às práticas de governança, podendo sugerir que essas companhias adotam práticas de governança para mitigar possíveis problemas de agência. Já as empresas com controle familiar apresentam resultado contrário, índices de alinhamento inferiores, sugerindo que a presença de controladores nestas companhias pode ser um substituto para as práticas de governança partindo do racional que os controladores por terem mais recursos investidos teriam maiores incentivos para monitorar os gestores (SILVEIRA, 2005) e não atribuiriam tanta importância à evidenciação de informações ao mercado.

Contudo, a média geral do índice de alinhamento às práticas de governança foi de 6.23 de um total de 16 pontos. Muitas recomendações ainda não foram adotadas pelas empresas, havendo ainda muito a ser aprimorado em relação ao alinhamento às práticas recomendadas de governança corporativa. 


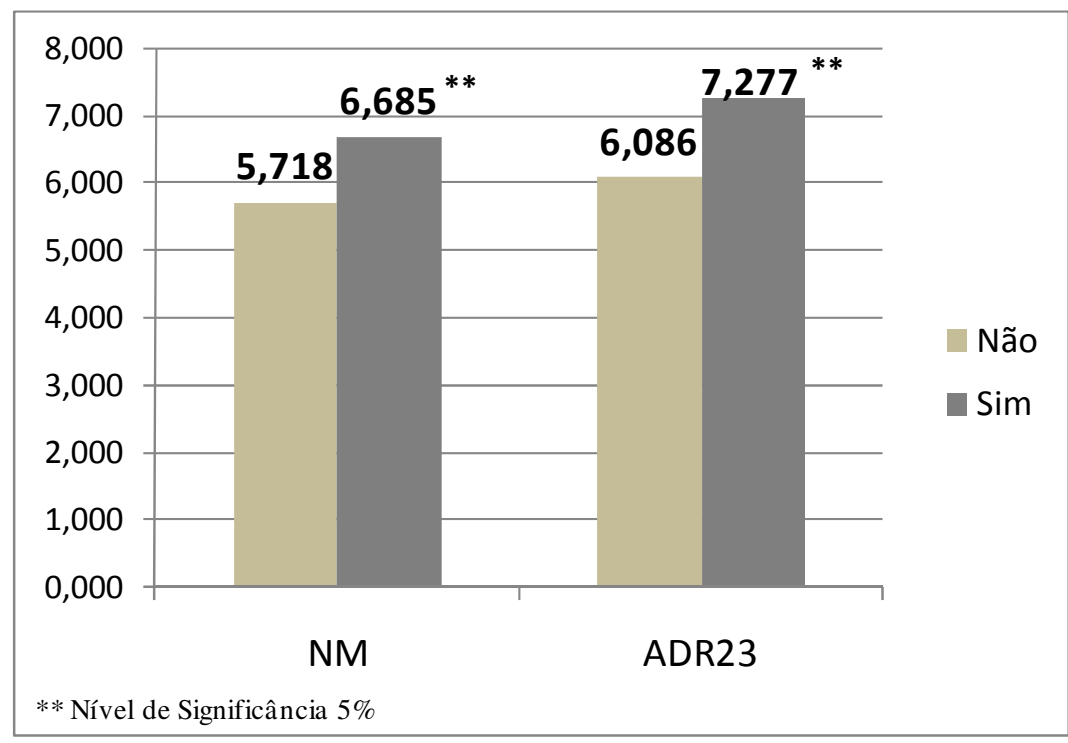

\section{Gráfico 2 - Teste de diferença de média entre índice de alinhamento das recomendações de GC em relação a negociação no NM e ADR 2 e 3}

No Gráfico 2 evidencia-se as diferenças entre os valores do índice de alinhamento às práticas de governança, em que as companhias listadas no Novo Mercado apresentam, em média, índice de 6.68 e as empresas que negociam ADR 2 e 3 nos Estados Unidos apresentam valores médios de 7.27. Todavia o valor de pontuação máxima do índice era de 16 pontos, portanto estes resultados estão aquém da metade do valor máximo mensurado pelo índice, mostrando que há ainda muito a ser aprimorado em relação à adoção de práticas recomendadas no que concerne à independência, disponibilidade de tempo, diversidade e comitês.

\subsubsection{Testes de diferença de médias - Subíndice de Independência}

Para o subíndice de independência há diferença significante na média das empresas com negociação no Novo Mercado, sugerindo que estas companhias apresentam maior nível de independência com média de 2.04 de um total de 5 pontos. Porém apesar de adotar algumas práticas em relação à independência dos conselhos, no geral, todas as empresas da amostra ainda apresentam baixos níveis de independência nos conselhos (média de 1.78), pois ficaram distantes da pontuação máxima para este subíndice (5 pontos), em pontuação inferior a metade dos pontos.

Verifica-se na Tabela 16 que as empresas com controle disperso apresentam índice de independência de 2.62, demonstrando significância estatística na diferença entre as 
empresas que têm outro tipo de controle. Já as empresas com controle compartilhado apresentam média inferior (1.62) para o nível de independência, sugerindo que a existência de controle compartilhado possa ser um substituto ao monitoramento esperado de empresas com maior nível de independência.

Tabela 16 - Teste de diferença de média - Nível de Independência

Teste de diferença de médias entre empresas listadas em segmentos com mais exigências de governança (Novo Mercado e ADR 2 e 3) e tipos de controle de propriedade em relação ao subíndice de independência (independência dos conselhos; independência do PCA; separação de cargos entre PCA e PE). PCA - Presidente do CA PE - Presidente Executivo. Pontuação máxima 5 pontos.

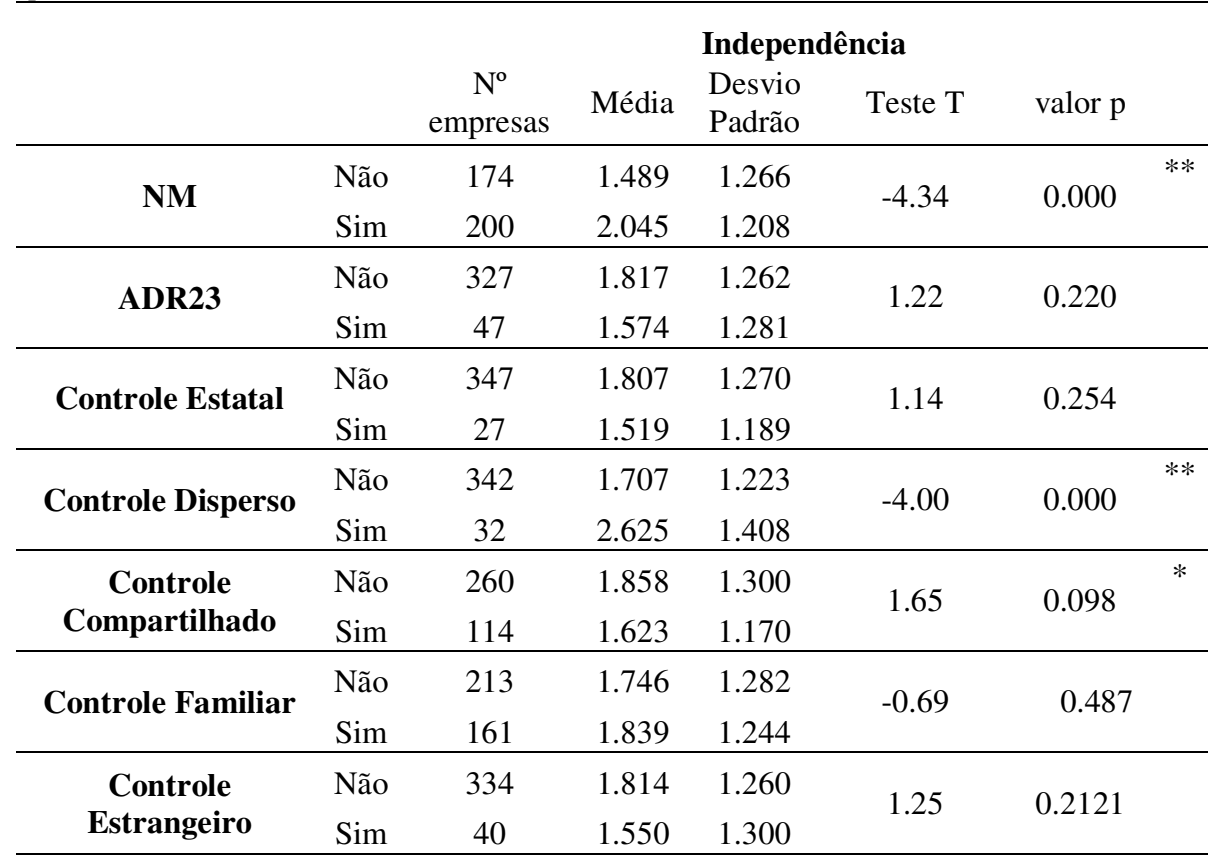

** Nível de significância 5\%

* Nível de significância $1 \%$

\subsubsection{Testes de diferença de médias - Subíndice de Disponibilidade de Tempo}

O índice de disponibilidade de tempo está relacionado ao conceito de busy board, no qual se sugere que em conselhos com muitos membros engajados em atividades em outros conselhos não há muita disponibilidade para a dedicação e comprometimento para desempenhar de maneira efetiva o papel de conselheiro (SANTOS et al., 2009). Para desempenhar o papel efetivamente é necessário que o conselheiro tenha disponibilidade de tempo para a preparação para as reuniões de conselho e também para participação no processo de tomada de decisões. Foi atribuído 1 ponto aos conselhos que tivessem menos que 3 conselheiros com participação em outro conselhos, sendo esta a pontuação máxima. 
Há diferença estatística para as empresas com negociação de ADR 2 e 3 (Tabela 17), estas apresentam níveis inferiores de disponibilidade de tempo. Já nas companhias com controle familiar o índice de disponibilidade de tempo apresenta média superior indicando que nestas empresas os conselhos são formados por conselheiros que tem menor nível de participação em outros conselhos.

Tabela 17 - Teste de diferença de média - Nível de Disponibilidade de Tempo Teste de diferença de médias entre empresas listadas em segmentos com mais exigências de governança (Novo Mercado e ADR 2 e 3) e tipos de controle de propriedade em relação ao subíndice de disponibilidade de tempo (conceito relacionado ao busy board presença de 3 ou mais conselheiros que participam em outros conselhos de diferentes empresas). Pontuação máxima 1 ponto.

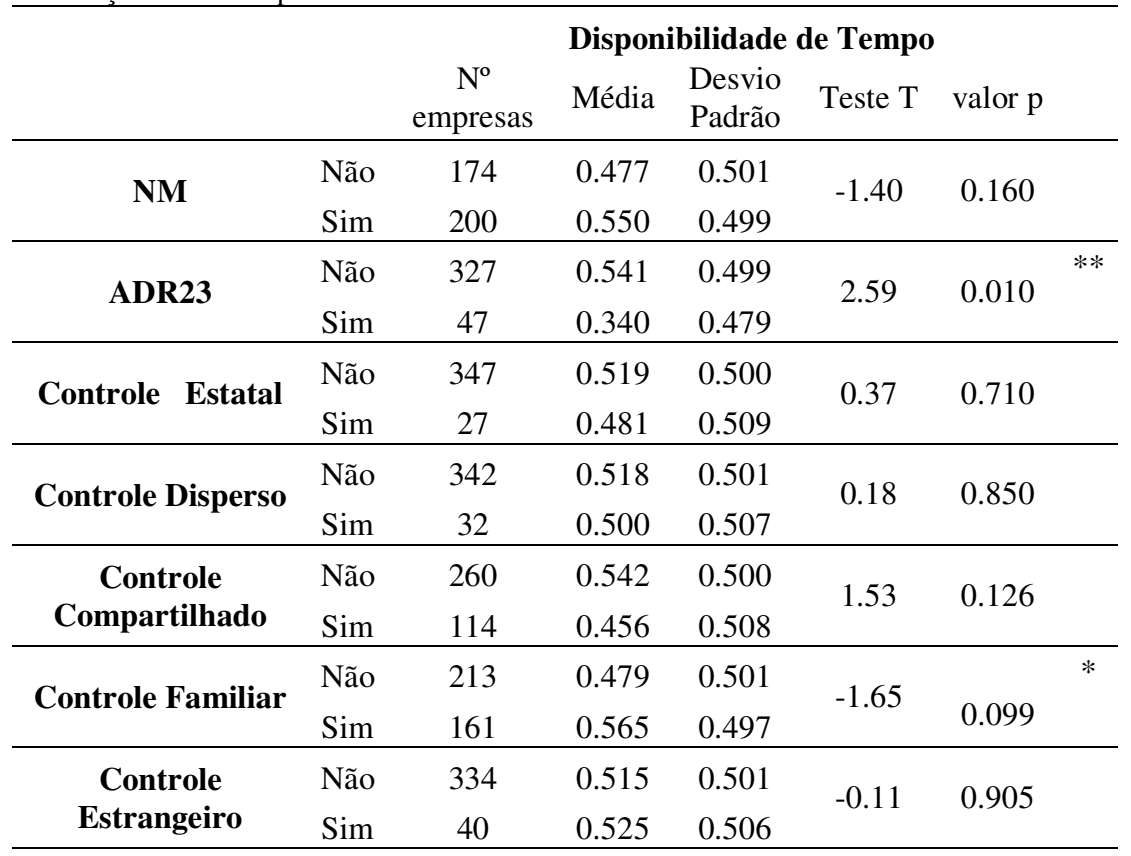

** Nível de significância 5\%

* Nível de significância $1 \%$

\subsubsection{Testes de diferença de médias - Subíndice de Diversidade}

A questão da diversidade nos conselhos é recomendada por códigos de governança e defendida por acadêmicos que destacam a importância de se ter uma mix diverso de pessoas no conselho de administração com o objetivo de ser efetivo (VAN DEN BERGHE; LEVRAU, 2004). O nível de diversidade foi verificado em relação à formação e qualificação dos conselheiros além da diversificação de idade e de gênero. A pontuação máxima para este subíndice foi de 7 pontos. 
Na Tabela 18, verifica-se que as empresas com negociação na Bolsa de Nova Iorque apresentam valores, em média, superiores de diversidade, possivelmente pelo fato de terem conselhos maiores com média de 9.3 membros, de acordo com a pesquisa do CEG e KPMG (2009), se comparadas às outras companhias brasileiras.

Tabela 18 - Teste de diferença de média - Nível de Diversidade

Teste de diferença de médias entre empresas listadas em segmentos com mais exigências de governança (Novo Mercado e ADR 2 e 3) e tipos de controle de propriedade em relação ao subíndice de diversidade (formação em contabilidade; diversificação de formações; diversificação de qualificações; diversidade etária; diversidade de gênero). Pontuação máxima 7 pontos.

Diversidade

\begin{tabular}{|c|c|c|c|c|c|c|c|c|c|}
\hline & & $\begin{array}{c}\mathrm{N}^{\mathbf{o}} \\
\text { empresas }\end{array}$ & Média & $\begin{array}{l}\text { Desvio } \\
\text { Padrão }\end{array}$ & Teste $\mathrm{T}$ & $\begin{array}{c}\text { valor } \\
\mathrm{p}\end{array}$ & & $\begin{array}{l}\text { Teste T } \\
\text { (Welch) }\end{array}$ & $\begin{array}{l}\text { valor } \\
\mathrm{p}\end{array}$ \\
\hline \multirow{2}{*}{ NM } & Não & 174 & 3.339 & 1.511 & & & & \multirow{2}{*}{-0.82} & \multirow{2}{*}{0.409} \\
\hline & $\mathrm{Sim}$ & 200 & 3.460 & 1.283 & & & & & \\
\hline \multirow{2}{*}{ ADR23 } & Não & 327 & 3.300 & 1.382 & \multirow{2}{*}{-3.88} & \multirow{2}{*}{0.000} & \multirow[t]{2}{*}{$* *$} & & \\
\hline & Sim & 47 & 4.128 & 1.262 & & & & & \\
\hline \multirow{2}{*}{$\begin{array}{l}\text { Controle } \\
\text { Estatal }\end{array}$} & Não & 347 & 3.300 & 1.348 & \multirow{2}{*}{-5.36} & \multirow{2}{*}{0.000} & $* *$ & & \\
\hline & Sim & 27 & 4.741 & 1.289 & & & & & \\
\hline \multirow{2}{*}{$\begin{array}{l}\text { Controle } \\
\text { Disperso }\end{array}$} & Não & 342 & 3.386 & 1.399 & \multirow{2}{*}{-0.80} & \multirow{2}{*}{0.421} & & & \\
\hline & Sim & 32 & 3.594 & 1.341 & & & & & \\
\hline \multirow{2}{*}{$\begin{array}{c}\text { Controle } \\
\text { Compartilhado }\end{array}$} & Não & 260 & 3.388 & 1.427 & \multirow{2}{*}{-0.32} & \multirow{2}{*}{0.749} & & & \\
\hline & Sim & 114 & 3.439 & 1.317 & & & & & \\
\hline \multirow{2}{*}{$\begin{array}{l}\text { Controle } \\
\text { Familiar }\end{array}$} & Não & 213 & 3.653 & 1.353 & \multirow{2}{*}{4.05} & \multirow[b]{2}{*}{0.000} & $* *$ & & \\
\hline & Sim & 161 & 3.075 & 1.381 & & & & & \\
\hline \multirow{2}{*}{$\begin{array}{c}\text { Controle } \\
\text { Estrangeiro }\end{array}$} & Não & 334 & 3.383 & 1.415 & \multirow{2}{*}{-0.82} & \multirow{2}{*}{0.4114} & & & \\
\hline & Sim & 40 & 3.575 & 1.196 & & & & & \\
\hline
\end{tabular}

** Nível de significância 5\%

As empresas com controle estatal apresentam índices de diversidade superior estatisticamente ao nível de significância de 5\%, com média de 4.74, esse fato pode ser em decorrência de apresentarem, em média, conselhos com tamanho maior (9.74 membros) que a média geral (7.07 membros) havendo assim maior diversificação de perspectivas e visões. Os resultados das empresas com controle familiar são contrários, apresentando média estatisticamente significante inferior de diversidade (3.07), sendo possível que devido ao menor grau de diversidade nos conselhos destas companhias haja menor nível de debate e discussões devido a pouca pluralidade, tendendo possivelmente a se tornar fóruns de debates monotemáticos e pouco produtivos. 


\subsubsection{Testes de diferença de médias - Subíndice de Comitês}

No que concerne ao subíndice de comitês, há diferenças significantes entre médias em relação às empresas do Novo Mercado e as que negociam ADR 2 e 3 (Tabela 19), estas apresentam médias superiores comparadas com as outras empresas. Observa-se que em geral as empresas têm média relativamente baixa para este subíndice em comparação com a pontuação máxima de 3 pontos. Os comitês como órgãos assessores dos conselhos são peças chave para que o funcionamento dos conselhos seja efetivo. Todavia, em geral, as empresas ainda não apresentam sistemas de governança estruturados com Comitê de Auditoria e Remuneração, já que a média geral para esses itens foi de 0.24 e 0.18 , respectivamente. Os resultados encontrados no Anuário de Governança não mostram muitos avanços neste sentido, $52.7 \%$ das empresas têm Comitê de Auditoria e apenas $40.9 \%$ têm Comitê de Remuneração (CAPITAL ABERTO, 2009).

As empresas de controle estatal e disperso apresentam valores médios diferentes estatisticamente em relação às outras empresas, sendo superiores ao serem comparados com as outras empresas, mostrando que há preocupação com a estruturação de comitês para apoio aos conselhos. Por outro lado, as empresas familiares, ao contrário, apresentam médias inferiores em relação a este subíndice, provavelmente devido à centralização das discussões no próprio conselho devido à concentração de controle. 
Tabela 19 - Teste de diferença de média - Comitês

Teste de diferença de médias entre empresas listadas em segmentos com mais exigências de governança (Novo Mercado e ADR 2 e 3) e tipos de controle de propriedade em relação ao subíndice de comitês (existência de comitês de Auditoria e Remuneração; presença de especialistas em contabilidade no comitê de Auditoria). Pontuação máxima 3 pontos.

\begin{tabular}{|c|c|c|c|c|c|c|c|c|c|c|}
\hline \multicolumn{11}{|c|}{ Comitês } \\
\hline & & $\begin{array}{c}\mathrm{N}^{\mathrm{o}} \\
\text { empresas }\end{array}$ & Média & $\begin{array}{l}\text { Desvio } \\
\text { Padrão }\end{array}$ & Teste $\mathrm{T}$ & $\begin{array}{l}\text { valor } \\
\mathrm{p}\end{array}$ & & $\begin{array}{l}\text { Teste T } \\
\text { (Welch) }\end{array}$ & $\begin{array}{c}\text { valor } \\
\mathrm{p}\end{array}$ & \\
\hline \multirow{2}{*}{ NM } & Não & 174 & 0.414 & 0.798 & & & & \multirow{2}{*}{-2.37} & \multirow{2}{*}{0.018} & $* *$ \\
\hline & Sim & 200 & 0.630 & 0.963 & & & & & & \\
\hline \multirow{2}{*}{ ADR23 } & Não & 327 & 0.428 & 0.825 & & & & \multirow{2}{*}{-5.05} & \multirow{2}{*}{0.000} & ** \\
\hline & Sim & 47 & 1.234 & 1.047 & & & & & & \\
\hline \multirow{2}{*}{$\begin{array}{l}\text { Controle } \\
\text { Estatal }\end{array}$} & Não & 347 & 0.496 & 0.878 & \multirow{2}{*}{-2.63} & \multirow{2}{*}{0.009} & \multirow[t]{2}{*}{$* *$} & & & \\
\hline & Sim & 27 & 0.963 & 1.018 & & & & & & \\
\hline \multirow{2}{*}{$\begin{array}{l}\text { Controle } \\
\text { Disperso }\end{array}$} & Não & 342 & 0.482 & 0.834 & & & & \multirow{2}{*}{-2.33} & \multirow{2}{*}{0.026} & ** \\
\hline & Sim & 32 & 1.031 & 1.307 & & & & & & \\
\hline \multirow{2}{*}{$\begin{array}{c}\text { Controle } \\
\text { Compartilhado }\end{array}$} & Não & 260 & 0.527 & 0.911 & \multirow{2}{*}{-0.08} & \multirow{2}{*}{\multicolumn{2}{|c|}{0.935}} & & & \\
\hline & Sim & 114 & 0.535 & 0.864 & & & & & & \\
\hline \multirow{2}{*}{$\begin{array}{l}\text { Controle } \\
\text { Familiar } \\
\end{array}$} & Não & 213 & 0.629 & 0.971 & & & & \multirow{2}{*}{2.57} & \multirow{2}{*}{\multicolumn{2}{|c|}{0.010}} \\
\hline & Sim & 161 & 0.398 & 0.769 & & & & & & \\
\hline \multirow{2}{*}{$\begin{array}{c}\text { Controle } \\
\text { Estrangeiro }\end{array}$} & Não & 334 & 0.551 & 0.908 & \multirow{2}{*}{1.34} & \multirow{2}{*}{\multicolumn{2}{|c|}{0.1804}} & & & \\
\hline & Sim & 40 & 0.350 & 0.770 & & & & & & \\
\hline
\end{tabular}

** Nível de significância $5 \%$

\subsubsection{Testes de diferença de médias - Índice de Evidenciação}

Para o índice de evidenciação os resultados estão apresentados na Tabela 20. O foco do índice foi em relação a políticas e práticas da empresa que se relacionam à transparência de informações sobre: riscos, gastos com auditoria, operações com partes relacionadas, remuneração dos administradores e código de ética.

Companhias com negociação de ADR 2 e 3 apresentam média significantemente maior em relação à evidenciação, possivelmente por estarem sujeitas a regras mais rígidas em relação à transparência exigida pela SEC nos Estados Unidos. 
Tabela 20 - Teste de diferença de média - Nível de Evidenciação

Teste de diferença de médias entre empresas listadas em segmentos com mais exigências de governança (Novo Mercado e ADR 2 e 3) e tipos de controle de propriedade em relação ao índice de evidenciação (gastos com auditoria; gestão de risco; operações com partes relacionadas; código de ética; remuneração dos administradores). Pontuação máxima 6 pontos.

\begin{tabular}{|c|c|c|c|c|c|c|c|c|c|}
\hline & & \multicolumn{8}{|c|}{ Evidenciação } \\
\hline & & $\begin{array}{c}\mathrm{N}^{\mathbf{o}} \\
\text { empresas }\end{array}$ & Média & $\begin{array}{l}\text { Desvio } \\
\text { Padrão }\end{array}$ & Teste $\mathrm{T}$ & $\begin{array}{c}\text { valor } \\
\mathrm{p}\end{array}$ & & $\begin{array}{l}\text { Teste T } \\
\text { (Welch) }\end{array}$ & $\begin{array}{c}\text { valor } \\
\mathrm{p}\end{array}$ \\
\hline \multirow{2}{*}{$\mathbf{N M}$} & Não & 174 & 0.971 & 1.218 & \multirow{2}{*}{-0.88} & \multirow{2}{*}{0.375} & & & \\
\hline & Sim & 200 & 1.080 & 1.145 & & & & & \\
\hline \multirow{2}{*}{ ADR23 } & Não & 327 & 0.905 & 1.108 & \multirow{2}{*}{-5.58} & \multirow{2}{*}{0.000} & $* *$ & & \\
\hline & Sim & 47 & 1.894 & 1.306 & & & & & \\
\hline \multirow{2}{*}{$\begin{array}{c}\text { Controle } \\
\text { Estatal }\end{array}$} & Não & 347 & 0.983 & 1.143 & \multirow{2}{*}{-2.77} & \multirow{2}{*}{0.006} & $* *$ & & \\
\hline & Sim & 27 & 1.630 & 1.471 & & & & & \\
\hline \multirow{2}{*}{$\begin{array}{l}\text { Controle } \\
\text { Disperso } \\
\end{array}$} & Não & 342 & 0.994 & 1.156 & \multirow{2}{*}{-1.89} & \multirow{2}{*}{0.059} & $*$ & & \\
\hline & Sim & 32 & 1.406 & 1.365 & & & & & \\
\hline \multirow{2}{*}{$\begin{array}{c}\text { Controle } \\
\text { Compartilhado }\end{array}$} & Não & 260 & 1.000 & 1.159 & \multirow{2}{*}{-0.72} & \multirow{2}{*}{0.467} & & & \\
\hline & Sim & 114 & 1.096 & 1.226 & & & & & \\
\hline \multirow{2}{*}{$\begin{array}{l}\text { Controle } \\
\text { Familiar }\end{array}$} & Não & 213 & 1.183 & 1.217 & \multirow{2}{*}{2.92} & \multirow{2}{*}{0.004} & $* *$ & & \\
\hline & Sim & 161 & 0.826 & 1.099 & & & & & \\
\hline \multirow{2}{*}{$\begin{array}{c}\text { Controle } \\
\text { Estrangeiro }\end{array}$} & Não & 334 & 1.039 & 1.224 & & & & & \\
\hline & Sim & 40 & 0.950 & 0.714 & & & & 0.67 & 0.500 \\
\hline
\end{tabular}

** Nível de significância 5\%

As empresas estatais e de capital disperso também apresentam média estatisticamente superiores para este índice em relação às outras empresas. No entanto as médias apresentadas são baixas em relação à pontuação máxima (6 pontos), as empresas com controle estatal com média de 1.63 e as de controle disperso 1.40, evidenciando-se que ainda é preciso aprimorar muito em relação a evidenciação de informações. Por outro lado, as empresas com controle familiar apresentam média inferior e estatisticamente significante, evidenciando-se que estas companhias têm níveis ainda mais baixos no que se refere à evidenciação.

Ao investigar se a presença de conselheiros com formação em contabilidade teria alguma relação com o nível de evidenciação das empresas; verificou-se, como ilustrado na Tabela 21 e Gráfico 3, que empresas que têm na composição do Comitê de Auditoria pessoas com formação em contabilidade apresentam média do índice de evidenciação superior estatisticamente. Estas evidências corroboram com os resultados encontrados por Krishnan e Lee (2008) que a presença de especialistas em contabilidade no comitê de auditoria complementa estruturas de governança corporativa forte nas empresas. 
Tabela 21 - Teste de diferença de média - Presença de Conselheiros com formação em Contabilidade

Teste de diferença de médias entre empresas com presença de conselheiros com formação de Contabilidade nos conselhos e empresas com presença de conselheiros ou externos com formação de Contabilidade no comitê de Auditoria em relação ao índice de evidenciação (gastos com auditoria; gestão de risco; operações com partes relacionadas; código de ética; remuneração dos administradores). Pontuação máxima 6 pontos.

Evidenciação

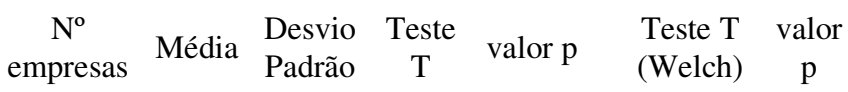

\begin{tabular}{|c|c|c|c|c|c|c|c|c|c|}
\hline \multirow{2}{*}{$\begin{array}{c}\text { Conselheiros com } \\
\text { formação em } \\
\text { Contabilidade no CA }\end{array}$} & Não & 282 & 1.050 & 1.165 & \multirow[t]{2}{*}{0.58} & \multirow[t]{2}{*}{0.562} & & & \\
\hline & Sim & 92 & 0.967 & 1.227 & & & & & \\
\hline $\begin{array}{l}\text { Conselheiros com } \\
\text { formação em } \\
\text { Contabilidade no }\end{array}$ & $\begin{array}{c}\text { Meno } \\
\mathrm{r}\end{array}$ & 338 & 0.932 & 1.072 & & & -3.55 & 0.001 & $* *$ \\
\hline Comitê de Auditoria & Maior & 36 & 1.944 & 1.672 & & & & & \\
\hline
\end{tabular}

** Nível de significância 5\%

O Gráfico 3 evidencia a diferença de médias entre as empresas que tem conselheiros ou membros externos com formação em contabilidade na composição do Comitê de Auditoria, as quais apresentam média de 1.94. Esta média é superior estatisticamente, quando comparada às empresas que não têm profissionais com essa formação na composição deste Comitê. Ressalta-se que não há inferência sobre causalidade nas evidências, somente constatação de diferenças de parâmetros nas empresas.

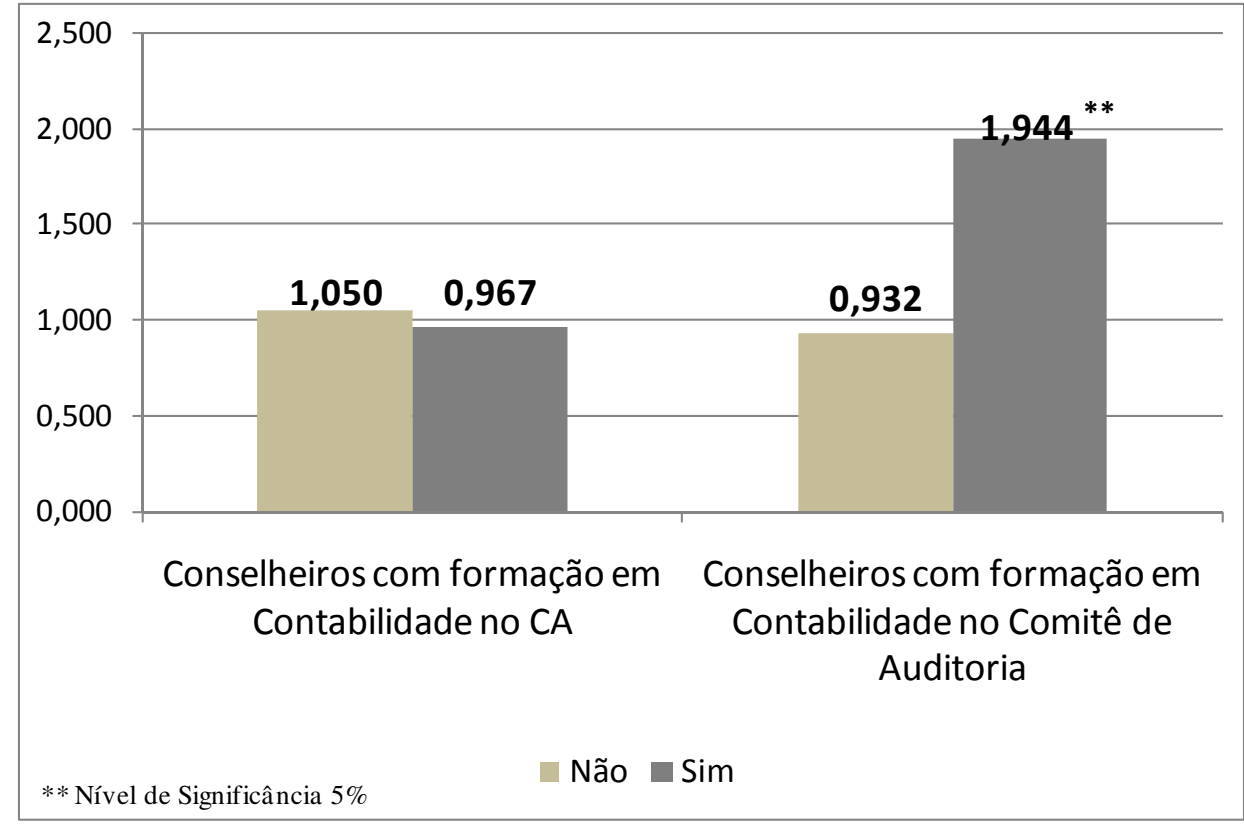

Gráfico 3 - Teste de diferença de média entre empresas com presença de conselheiros com formação em Contabilidade no CA e Comitê de Auditoria em relação ao índice de evidenciação 


\subsubsection{Testes de diferença de médias - Índice de Evidenciação e Índice de Alinhamento de práticas de governança corporativa}

Com o objetivo de verificar diferenças nos níveis de evidenciação das empresas separou-se em duas categorias a partir da mediana as empresas com maiores e menores índices de alinhamento às práticas de governança e realizou-se o teste de diferença de médias apresentado na Tabela 22.

Observa-se que as empresas com maiores índices de alinhamento às práticas de governança corporativa não apresentam diferenças significativas nas médias em relação ao nível de evidenciação, com 5\% de significância.

Tabela 22 - Teste de diferença de média - Nível de Evidenciação e Alinhamento de GC Teste de diferença de médias entre empresas com maiores e menores índices de alinhamento às práticas de governança (independência, disponibilidade de tempo, diversidade e comitês) em relação ao índice de evidenciação (gastos com auditoria; gestão de risco; operações com partes relacionadas; código de ética; remuneração dos administradores). Pontuação máxima 6 pontos.

\begin{tabular}{lcccccc}
\hline & & \multicolumn{5}{c}{ Evidenciação } \\
& $\mathrm{N}^{\mathbf{0}}$ & Média & $\begin{array}{c}\text { Desvio } \\
\text { empresas }\end{array}$ & Teste T & valor $\mathrm{p}$ \\
\hline \multirow{2}{*}{ Alinhamento de GC } & Menor & 133 & 1.015 & 1.128 & -0.17 & 0.8613 \\
& Maior & 241 & 1.037 & 1.209 & & \\
\hline
\end{tabular}

** Nível de significância 5\%

As empresas com maiores índices de alinhamento às práticas de governança apresentam média de nível de evidenciação de 1.03 enquanto as outras empresas com menores índices de alinhamento de governança têm média de 1.01 (Gráfico 4). Destaca-se ainda que a média do índice de evidenciação se apresenta abaixo da metade da pontuação máxima mensurada de 6 pontos. Sendo assim, a questão da divulgação das informações por parte das empresas deverá ser ainda muito aprimorada. A Comissão de Valores Mobiliários (CVM) com a Instrução CVM n 480/09³ tem trabalhado com o intuito de melhorar o nível de evidenciação das empresas, no que se relaciona à remuneração dos administradores, gerenciamento de risco, operações com pares relacionadas entre outros. Esta instrução melhora a quantidade e qualidade das informações que são colocadas à disposição dos investidores e do mercado periodicamente, trazendo as regras brasileiras para padrões muito próximos daqueles recomendados internacionalmente.

\footnotetext{
${ }^{3}$ Instrução CVM no 480 - Estabelece as regras de registro de emissores de valores mobiliários admitidos à negociação em mercados regulamentados, bem como o regime informacional a que tais emissores estão sujeitos. A Instrução aprofunda o nível de informação em alguns tópicos: transações com partes relacionadas, comentários dos diretores, riscos de mercado, assembleias gerais e administração, e remuneração dos administradores.
} 


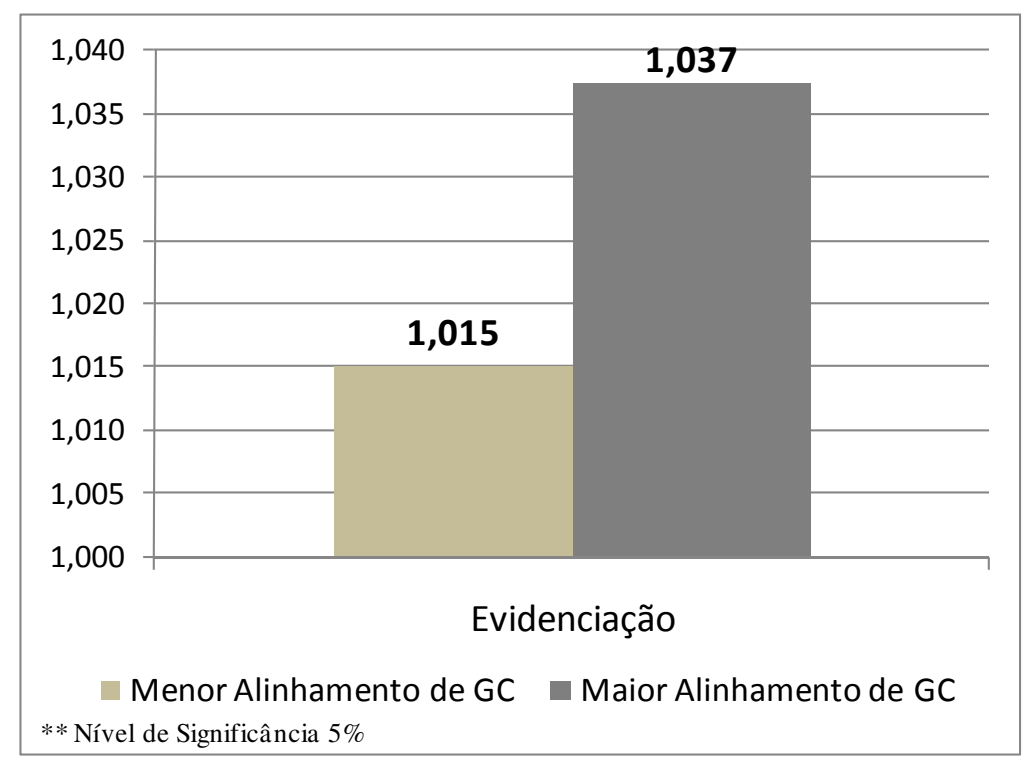

Gráfico 4 - Teste de diferença de média entre índice de evidenciação e índice de alinhamento às práticas de GC

\subsubsection{Associações entre nível de evidenciação e variáveis explicativas}

Os resultados das correlações do nível de evidenciação (gastos com auditoria; gestão de risco; operações com partes relacionadas; código de ética; remuneração dos administradores) com as diversas variáveis explicativas utilizadas nesta pesquisa: índice de alinhamento de governança (independência, disponibilidade de tempo, diversidade e comitês); tamanho do conselho; negociação de ADR 2 e 3 na Bolsa de Nova Iorque; listagem no Novo Mercado - NM; propriedade (logaritmo do percentual de propriedade do capital votante dos 3 maiores acionistas); tipo de controle (estatal, compartilhado, disperso, familiar, estrangeiro); tamanho da empresa (logaritmo receita operacional líquida), estão apresentados na Tabela 23.

Observa-se que a maioria das correlações apresenta significância estatística ao nível de $5 \%$. Existe associação positiva e significante entre nível de evidenciação e alinhamento às práticas de governança corporativa com coeficiente de correlação de 0.20. Adicionalmente, empresas com negociação de ADR 2 e 3 na Bolsa de Nova Iorque apresentam correlação positiva e estatisticamente significante com o nível de evidenciação. Estes resultados vão ao encontro da hipótese de complementaridade entre a adoção de práticas de governança corporativa e evidenciação de informações. Outro resultado que se destaca é a associação negativa e significante da variável "controle 
familiar" com a variável "nível de evidenciação", sugerindo que companhias com este perfil teriam associação negativa com a evidenciação de informações já que os controladores teriam mais acesso a informações por estarem no controle e, dessa forma, estas companhias evidenciariam menos informações ao mercado. A variável de controle "tamanho da empresa", mensurada pelo logaritmo da receita operacional líquida, apresenta associação positiva com o nível de evidenciação confirmando a ideia de que empresas maiores teriam maiores incentivos para evidenciar informações já que teriam custos relativamente mais baixos.

Os resultados encontrados evidenciam associações esperadas entre as variáveis baseadas nas predições teóricas e resultados empíricos abordados na revisão da literatura. Para confirmar estas evidências e verificar a consistência dos resultados é necessário partir para análises mais sofisticadas estatisticamente. 
Tabela 23 - Resultados das correlações entre nível de evidenciação, alinhamento às práticas de GC e variáveis explicativas

Índice de evidenciação (gastos com auditoria; gestão de risco; operações com partes relacionadas; código de ética; remuneração dos administradores); Alinhamento às práticas de governança (independência, disponibilidade de tempo, diversidade e comitês). A descrição das variáveis explicativas e de controle estão no quadro 3 e 1, respectivamente.

\begin{tabular}{|c|c|c|c|c|c|c|c|c|c|c|c|c|}
\hline \multirow[b]{2}{*}{ Evidenciação } & Evidenciação & \multirow[t]{2}{*}{$\begin{array}{c}\text { Alinhamento } \\
\text { GC }\end{array}$} & \multirow[t]{3}{*}{$\begin{array}{l}\text { Tam } \\
\text { CA }\end{array}$} & \multirow[t]{6}{*}{$\begin{array}{l}\text { ADR } 2 \\
\text { e } 3\end{array}$} & \multirow[t]{8}{*}{ NM } & \multirow[t]{10}{*}{ Propriedade } & \multirow[t]{12}{*}{ C_Estatal } & \multirow[t]{14}{*}{ C_Compartilhado } & \multirow[t]{16}{*}{ C_Disperso } & \multirow[t]{18}{*}{ C_Familiar } & \multirow[t]{20}{*}{ C_Estrangeiro } & \multirow[t]{22}{*}{$\begin{array}{c}\text { Tamanho } \\
\text { (Ln_Rec. Liq) }\end{array}$} \\
\hline & 1.000 & & & & & & & & & & & \\
\hline Alinhamento GC & 0.207 & 1.000 & & & & & & & & & & \\
\hline \multirow{3}{*}{ Tam_CA } & $(0.000)$ & & & & & & & & & & & \\
\hline & 0.266 & 0.356 & 1.000 & & & & & & & & & \\
\hline & $(0.000)$ & $(0.000)$ & & & & & & & & & & \\
\hline \multirow{2}{*}{ ADR 2 e 3} & 0.278 & 0.176 & 0.342 & 1.000 & & & & & & & & \\
\hline & $(0.000)$ & $(0.001)$ & $(0.000)$ & & & & & & & & & \\
\hline \multirow[t]{2}{*}{$\mathrm{NM}$} & 0.046 & 0.215 & -0.009 & -0.212 & 1.000 & & & & & & & \\
\hline & $(0.375)$ & $(0.000)$ & $(0.858)$ & $(0.000)$ & & & & & & & & \\
\hline \multirow[t]{2}{*}{ Propriedade } & 0.081 & -0.217 & 0.095 & 0.125 & -0.559 & 1.000 & & & & & & \\
\hline & $(0.144)$ & $(0.000)$ & $(0.084)$ & $(0.024)$ & $(0.000)$ & & & & & & & \\
\hline \multirow[t]{2}{*}{ C_Estatal } & 0.142 & 0.183 & 0.267 & 0.144 & -0.133 & 0.176 & 1.000 & & & & & \\
\hline & $(0.006)$ & $(0.000)$ & $(0.000)$ & $(0.005)$ & $(0.010)$ & $(0.001)$ & & & & & & \\
\hline \multirow[t]{2}{*}{ C_Compartilhado } & 0.038 & -0.054 & 0.132 & 0.170 & -0.069 & -0.032 & -0.185 & 1.000 & & & & \\
\hline & $(0.467)$ & $(0.298)$ & $(0.011)$ & $(0.001)$ & $(0.180)$ & $(0.567)$ & $(0.000)$ & & & & & \\
\hline \multirow[t]{2}{*}{ C_Disperso } & 0.098 & 0.207 & 0.005 & 0.028 & 0.228 & -0.469 & -0.085 & -0.203 & 1.000 & & & \\
\hline & $(0.059)$ & $(0.000)$ & $(0.918)$ & $(0.586)$ & $(0.000)$ & $(0.000)$ & $(0.099)$ & $(0.000)$ & & & & \\
\hline \multirow[t]{2}{*}{ C_Familiar } & -0.150 & -0.139 & -0.306 & -0.199 & 0.010 & 0.122 & -0.243 & -0.576 & -0.266 & 1.000 & & \\
\hline & (0.004) & $(0.007)$ & $(0.000)$ & $(0.000)$ & $(0.850)$ & $(0.028)$ & $(0.000)$ & $(0.000)$ & $(0.000)$ & & & \\
\hline \multirow[t]{2}{*}{ C_Estrangeiro } & -0.023 & -0.036 & 0.065 & -0.079 & -0.007 & 0.116 & -0.097 & -0.229 & -0.106 & -0.301 & 1.000 & \\
\hline & $(0.653)$ & $(0.484)$ & $(0.212)$ & $(0.127)$ & $(0.896)$ & $(0.036)$ & $(0.062)$ & $(0.000)$ & $(0.041)$ & $(0.000)$ & & \\
\hline \multirow{2}{*}{$\begin{array}{l}\text { Tamanho } \\
\text { (Ln_Rec. Liq) }\end{array}$} & 0.324 & 0.238 & 0.423 & 0.507 & -0.182 & 0.178 & 0.203 & 0.085 & -0.033 & -0.188 & 0.044 & 1.000 \\
\hline & $(0.000)$ & $(0.000)$ & $(0.000)$ & $(0.000)$ & $(0.001)$ & $(0.002)$ & $(0.000)$ & $(0.114)$ & $(0.547)$ & $(0.000)$ & $(0.414)$ & \\
\hline
\end{tabular}

Nível de significância $5 \%$ 


\subsection{Resultados da análise em painel}

Nas análises exploratórias foram evidenciadas associações e diferenças de parâmetros nas empresas ao relacionar os índices de evidenciação e alinhamento às práticas de governança. Com o intuito de verificar o impacto de mecanismos internos de governança na evidenciação das empresas foram realizadas regressões com dados em painel.

A relação entre o nível de evidenciação e a adoção de mecanismos de governança pode ser complementar ou substituta. Se for complementar, espera-se uma relação positiva entre as variáveis, pois a adoção de mais mecanismos de governança fortaleceria o controle interno e o papel de monitoramento das companhias e em decorrência haveria maior nível de evidenciação (JENSEN; MEKLING, 1976; HO; WONG, 2001). Por outro lado, se a relação for substituta espera-se sinal negativo nos coeficientes obtidos nas regressões, ou seja, empresas com maior nível de evidenciação apresentariam pior estrutura de governança, assim o menor monitoramento interno seria compensado pela transparência na evidenciação (HO; WONG, 2001).

Com a organização dos dados em painel, primeiramente foi realizada regressão com abordagem do método de mínimos quadrados ordinários (MQO) e depois foram realizados procedimentos de efeitos fixos e efeitos aleatórios. Todos os modelos foram estimados com padrões robustos para heterocedasticidade. Assumiu-se normalidade dos dados, já que segundo Brooks (2008), em amostras suficientemente grandes a violação da normalidade dos dados é virtualmente inconsequente, pois segue o teorema do limite central, no qual as médias das amostras convergem para uma distribuição normal.

Ao avaliar os resultados das regressões, Tabela 24, na regressão com abordagem do método de mínimos quadrados ordinários (MQO), verifica-se relação positiva entre a variável independente "alinhamento às práticas de governança" e a variável dependente "nível de evidenciação", apesar dos resultados não serem estatisticamente significantes. Algumas das variáveis de controle apresentam relação significante, a saber, empresas com negociação de ADR 2 e 3 e empresas listadas no Novo Mercado apresentam relação positiva com o nível de evidenciação corroborando a ideia de que empresas com maiores exigências em relação à mecanismos de governança apresentariam maior evidenciação de informações. Estes resultados dão suporte à hipótese de complementaridade na relação entre divulgação de 
informações e alinhamento às práticas de governança. A variável de propriedade, ou direito de controle, também apresenta relação positiva com o nível de evidenciação. As variáveis de tipo de controle compartilhado, familiar e estrangeiro apresentam relação significante negativa, sugerindo que empresas com estes perfis apresentariam menor evidenciação, provavelmente pelo fato de terem o controle como mecanismo de monitoramento e a evidenciação acabaria não sendo um mecanismo de tanta relevância. As variáveis de controle setorial indicam que empresas do setor financeiro e de materiais básicos apresentam maior evidenciação, resultado racionalizado pela regulação mais rígida em torno da transparência, no setor financeiro principalmente. Por fim, a variável de controle tamanho da empresa apresenta relação positiva e significante evidenciando que empresas maiores evidenciariam mais informações possivelmente por terem custos de evidenciação relativamente menores.

Com o objetivo de verificar a adequação dos dados com as diferentes abordagens realizou-se o teste de Breusch-Pagan para verificar a adequação entre os modelos de MQO e efeito aleatório. Os resultados, apresentados na Tabela 24, indicaram ao nível de significância de $5 \%$, a não aceitação da hipótese nula, na qual se assume que a variância dos resíduos que refletem diferenças individuais é igual a zero, assim o teste sugere a utilização da abordagem de efeitos aleatórios. Para escolher entre as abordagens de efeitos fixos e aleatórios utilizou-se o teste de Hausman, visando verificar se existe correlação entre os fatores não observados e as variáveis explicativas, assumindo que os erros idiossincráticos e as variáveis explicativas são não correlacionados ao longo do tempo. Sob a hipótese nula deste teste assume-se a não correlação entre os efeitos individuais e que a hipótese alternativa assume correlação entre os efeitos individuais, neste caso devendo-se utilizar a abordagem de efeitos fixos.

Decidiu-se pelo método de efeitos aleatórios, pois o Teste de Hausman, ao nível de significância de 5\%, indica a aceitação da hipótese nula, ou seja, não há correlação entre os efeitos individuais, não havendo diferenças sistêmicas entre os coeficientes das abordagens de efeitos aleatórios e efeitos fixos. 


\section{Tabela 24 - Resultados das regressões}

Resultados das regressões MQO, Efeitos fixos (EF) e efeitos aleatórios (EA) que estimaram os efeitos no nível de evidenciação (gastos com auditoria; gestão de risco; operações com partes relacionadas; código de ética; remuneração dos administradores - Pontuação máxima 6 pontos) das variáveis 1 ) índice de alinhamento de governança (independência, disponibilidade de tempo, diversidade e comitês); 2) T amanho do conselho; 3) Negociação de ADR 2 e 3 na Bolsa de Nova Iorque; 4) Listagem no Novo Mercado - NM; 5) Propriedade (Logaritmo do percentual de propriedade do capital votante dos 3 maiores acionistas); 6) Tipo de controle (estatal, compartilhado, disperso, familiar, estrangeiro); 7) Dummy setorial; 8) Tamanho da empresa (Logaritmo receita operacional líquida). Todos os modelos foram estimados com erros padrões robustos para heterocedasticidade. Na tabela estão apresentados os coeficientes e abaixo entre parênteses o p-valor.

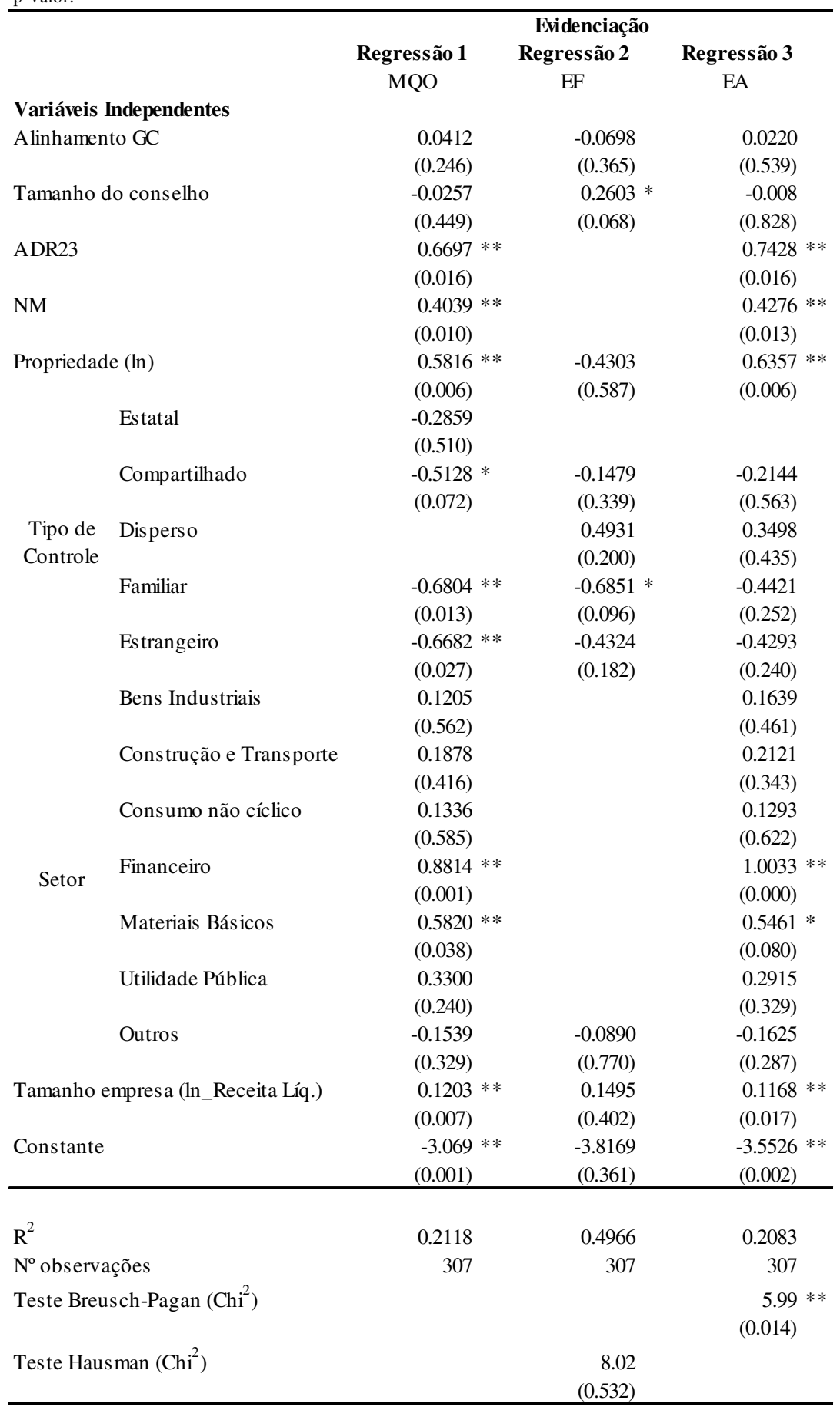

** Nível de significância 5\%

* Nível de significância $10 \%$ 
A análise dos resultados da regressão com o método de efeitos aleatórios (Tabela 24) apresenta evidências similares ao encontrado com o método MQO. Observa-se relação positiva entre a "variável alinhamento às práticas de governança" e a variável "nível de evidenciação", apesar dos resultados também não serem significantes ao nível de 5\%. Em relação às variáveis de controle, poucas apresentam relação significante. As variáveis que representam empresas com negociação de ADR 2 e 3 e empresas listadas no Novo Mercado apresentam relação positiva com o nível de evidenciação confirmando a hipótese de complementaridade na relação entre evidenciação e adoção de práticas de governança, pois nestes segmentos as empresas estão sujeitas a mais exigências nesse sentido. A variável de propriedade mostra relação positiva com evidenciação. As variáveis de controle setorial também indicam que empresas do setor financeiro e de materiais básicos apresentariam maior evidenciação. Enquanto que a variável de controle "tamanho da empresa" apresenta relação positiva e significante evidenciando que empresas maiores evidenciariam mais informações baseada na ideia de terem custos de evidenciação relativamente menores.

Como testes de robustez decidiu-se por analisar as regressões sem as variáveis ADR 2 e 3 e Novo Mercado para verificar se estas variáveis influenciaram os resultados obtidos na relação entre o alinhamento das práticas de governança e o nível de evidenciação. Também foi realizada regressão com o modelo Tobit, com o objetivo de mitigar a limitação das variáveis censuradas decorrente da utilização do índice de evidenciação como variável dependente. Para tanto os resultados são apresentados na Tabela 25.

Os resultados se mantêm robustos, no entanto, a significância da variável alinhamento às práticas de governança corporativa não foi suficiente estatisticamente ao nível de $5 \%$. Porém os resultados não suportam a hipótese de complementaridade de mecanismos, ou seja, não há relação entre as variáveis desta pesquisa. Todavia, a relação de complementaridade é confirmada entre o nível de evidenciação e as variáveis referentes à negociação no Novo Mercado e na Bolsa de Nova Iorque (empresas com emissão de ADR nível 2 e 3 ) (Tabela 24). Este fato pode sugerir que a adoção de práticas recomendadas em relação aos mecanismos de governança do CA nestas empresas fortaleceria o controle interno e o papel de monitoramento nas companhias com isso os administradores não teriam incentivos em deter informações, fato que afetaria o nível de divulgação de informações proporcionando maior nível de evidenciação. 


\section{Tabela 25 - Resultados das regressões - Teste de robustez}

Resultados das regressões MQO, Efeitos fixos (EF) e efeitos aleatórios (EA) que estimaram os efeitos no nível de evidenciação (gastos com auditoria; gestão de risco; operações com partes relacionadas; código de ética; remuneração dos administradores Pontuação máxima 6 pontos) das variáveis 1) índice de alinhamento de governança (independência, disponibilidade de tempo, diversidade e comitês); 2) Tamanho do conselho; 3) Propriedade (Logaritmo do percentual de propriedade do capital votante dos 3 maiores acionistas); 4) Tipo de controle (estatal, compartilhado, disperso, familiar, estrangeiro); 5) Dummy setorial; 6) Tamanho da empresa (Logaritmo receita operacional líquida). Todos os modelos foram estimados com erros padrões robustos para heterocedasticidade. Na tabela estão apresentados os coeficientes e abaixo entre parênteses o p-valor.

\begin{tabular}{|c|c|c|c|c|c|}
\hline & & $\begin{array}{c}\text { Regressão } 1 \\
\text { MQO }\end{array}$ & $\begin{array}{c}\text { Regressão } 2 \\
\text { EF }\end{array}$ & $\begin{array}{c}\text { Regressão } 3 \\
\text { EA }\end{array}$ & $\begin{array}{c}\text { Regressão } 4 \\
\text { Tobit }\end{array}$ \\
\hline \multicolumn{6}{|c|}{ Variáveis Independentes } \\
\hline \multirow{2}{*}{\multicolumn{2}{|c|}{ Alinhamento GC }} & 0.5451 & -0.0698 & 0.0353 & 0.0776 \\
\hline & & $(0.139)$ & $(0.365)$ & $(0.346)$ & $(0.149)$ \\
\hline \multirow{2}{*}{\multicolumn{2}{|c|}{ Tamanho do conselho }} & -0.0055 & $0.2603 *$ & 0.0167 & 0.0095 \\
\hline & & $(0.870)$ & $(0.068)$ & $(0.655)$ & $(0.848)$ \\
\hline \multirow{2}{*}{\multicolumn{2}{|c|}{ Propriedade $(\ln )$}} & $0.3858 * *$ & 0.4144 & $0.4511 * *$ & 0.4401 \\
\hline & & $(0.033)$ & $(0.629)$ & $(0.026)$ & $(0.176)$ \\
\hline \multirow{2}{*}{\multicolumn{2}{|c|}{ Controle_estatal }} & -0.3995 & & & -0.8386 \\
\hline & & $(0.360)$ & & & $(0.178)$ \\
\hline \multirow{2}{*}{\multicolumn{2}{|c|}{ Controle_compartilhado }} & $-0.5339 *$ & -0.1479 & -0.1306 & -0.8761 \\
\hline & & $(0.056)$ & $(0.339)$ & $(0.733)$ & $(0.044) * *$ \\
\hline \multirow{12}{*}{$\begin{array}{l}\text { Tipo de } \\
\text { Controle }\end{array}$} & Controle_disperso & & 0.4931 & 0.4663 & \\
\hline & & & $(0.200)$ & $(0.302)$ & \\
\hline & Controle_familiar & $-0.7248 * *$ & $-0.6851 *$ & -0.3915 & -1.1875 \\
\hline & & $(0.006)$ & $(0.096)$ & $(0.320)$ & $(0.006) * *$ \\
\hline & Controle_estrangeiro & $-0.7406 * *$ & -0.4324 & -0.4001 & -0.9698 \\
\hline & & $(0.013)$ & $(0.182)$ & $(0.281)$ & $(0.066) *$ \\
\hline & Bens Industriais & 0.0862 & & 0.1308 & 0.4048 \\
\hline & & $(0.667)$ & & $(0.552)$ & $(0.280)$ \\
\hline & Construção e Transporte & 0.2907 & & 0.3551 & 0.6714 \\
\hline & & $(0.139)$ & & $(0.108)$ & $(0.058) *$ \\
\hline & Consumo não cíclico & 0.2253 & & 0.2238 & 0.4762 \\
\hline & & $(0.334)$ & & $(0.392)$ & $(0.217)$ \\
\hline \multirow{8}{*}{ Setor } & Financeiro & $0.8679 * *$ & & $0.9918 * *$ & 1.4655 \\
\hline & & $(0.001)$ & & $(0.001)$ & $(0.000) * *$ \\
\hline & Materiais Básicos & $0.4967 *$ & & 0.4452 & 0.9388 \\
\hline & & $(0.081)$ & & $(0.166)$ & $(0.022) * *$ \\
\hline & Utilidade Pública & 0.3705 & & 0.3135 & 0.7767 \\
\hline & & $(0.201)$ & & $(0.310)$ & $(0.100)$ * \\
\hline & Outros & -0.1827 & -0.8908 & -0.1700 & -0.2723 \\
\hline & & $(0.239)$ & $(0.770)$ & $(0.252)$ & $(0.333)$ \\
\hline \multirow{2}{*}{\multicolumn{2}{|c|}{ Tamanho empresa (ln_Receita Líq.) }} & $0.1637 * *$ & -0.1495 & $0.1626 * *$ & 0.2926 \\
\hline & & $(0.000)$ & $(0.402)$ & $(0.001)$ & $(0.000)$ \\
\hline \multirow{2}{*}{\multicolumn{2}{|c|}{ Constante }} & $-2.7517 * *$ & -3.8169 & $-3.445 * *$ & -5.4559 \\
\hline & & $(0.001)$ & $(0.361)$ & $(0.001)$ & $(0.000)$ \\
\hline \multicolumn{2}{|l|}{$\mathrm{R}^{2}$} & 0.1785 & 0.4966 & 0.1741 & 0.0667 \\
\hline \multicolumn{2}{|c|}{$\mathrm{N}^{\circ}$ observações } & 307 & 307 & 307 & 307 \\
\hline \multirow{2}{*}{\multicolumn{2}{|c|}{ Teste Breusch-Pagan $\left(\mathrm{Chi}^{2}\right)$}} & & & $5.43 * *$ & \\
\hline & & & & 0.020 & \\
\hline \multirow{2}{*}{\multicolumn{2}{|c|}{ Teste Hausman $\left(\mathrm{Chi}^{2}\right)$}} & & 7.27 & & \\
\hline & & & $(0.608)$ & & \\
\hline \multirow{2}{*}{\multicolumn{2}{|c|}{$\mathrm{LR}\left(\mathrm{Chi}^{2}\right)$}} & & & & $62.48^{* \star}$ \\
\hline & & & & & $(0.000)$ \\
\hline
\end{tabular}

** Nível de significância 5\%

* Nível de significância $10 \%$ 


\subsection{Resumo dos resultados}

Para finalizar a análise, vale destacar os resultados mais expressivos, buscando responder à questão central desta pesquisa e alcançar o objetivo do trabalho: verificar a relação entre o alinhamento às práticas recomendadas de governança relacionadas ao CA e o nível de evidenciação das empresas.

Resultante das análises descritivas, as evidências que se destacam são:

- Os conselhos continuam não tendo maioria de independentes como recomendado pelo IBGC (2009). Os percentuais de conselheiros independentes em 2007 foram de $34.6 \%$ e 25.4\% em 2008. Corroborando com os resultados do Anuário de Governança Corporativa com média de 30.4\% de conselheiros independentes (CAPITAL ABERTO, 2009).

- Apesar dos conselhos serem aparentemente compostos por maioria de externos $85.7 \%$ em 2007, 35.1\% dos conselheiros foram classificados como afiliados, ou seja, tinham algum vínculo com o controlador ou com a companhia. Em 2008, estes percentuais eram de $87.3 \%$ e $35.6 \%$, respectivamente. Somando se o percentual de conselheiros afiliados com os conselheiros internos e também internos e afiliados, tem se $49.4 \%$ em 2007 e $48.3 \%$ em 2008, evidenciando que aproximadamente metade da composição dos conselhos tem algum vínculo, pessoal ou profissional, com a companhia ou com controlador/majoritário. A ideia de que os conselhos são compostos por grande maioria de externos não pode ser defendida.

- Assim como encontrado em Guerra (2009), evidencia-se o fato da potencial concentração de poder do presidente do conselho, 63.7\% (2007) e 64.9\% (2008) dos presidentes dos conselhos das empresas apresentam algum vínculo familiar ou de relação profissional com o grupo controlador (conselheiros afiliados). Este fato pode sugerir dominância dos controladores nos conselhos com a ocupação de pessoas com vínculos que poderiam estar mais propensas a dominarem o conselho.

- $\quad$ O percentual de conselhos que tem algum conselheiro com participação em outros conselhos evoluiu ao longo dos anos, esse percentual é de $78.5 \%$ em 2007 e $83.2 \%$ em 2008, comparado com pesquisas anteriores com resultado de 65\% em 2005 (SANTOS et al., 2009). 
- As formações mais comuns entre os conselheiros são: Engenharia, Administração, Economia e Direito. Os profissionais da área contábil têm representação de apenas 4.0\% (2007) e 5.2\% (2008). Evidencia-se participação ainda incipiente da classe contábil na composição dos conselhos.

- Conselheiros com mestrado e/ou doutorado representam somente 22.4\% (2007) e $29.9 \%$ (2008). Estes resultados estão em concordância com as evidências de pouca presença de acadêmicos nos conselhos reportado por Black et al. (2008).

- A maior parte das empresas, 125 em 2007 e 167 em 2008, apresentam diversidade moderada, com membros do conselho formados em 3 a 5 diferentes graduações.

- $\quad$ Existe predominância masculina nos conselhos, $94.4 \%$ das posições são ocupadas por homens. Em apenas 5 empresas em 2007 e 6 empresas em 2008 o cargo de presidente do conselho é ocupado por conselheira. As empresas que não têm nenhuma conselheira ainda são grande maioria $(72.1 \%, 2007 ; 68.8 \%$ 2008).

- A maior parte dos conselheiros se encontra na faixa etária acima de 51 anos $(47.3 \%$, 2007; 43.6\%, 2008) corroborando a ideia de que estes profissionais apresentam mais maturidade para tratar dos assuntos de alta gestão que são alvo de decisões dos conselhos.

Os resultados mais relevantes resultante das análises exploratórias são apresentados a seguir:

- Como esperado há diferença significante entre o índice de alinhamento às práticas de governança corporativa nas empresas listadas no Novo Mercado e com negociação de ADR 2 e 3 na Bolsa de Nova Iorque devido a maior exigência de mecanismos de governança. No entanto, a média do índice de alinhamento às práticas de governança foi de 6.23 de um total de 16 pontos. Com isso verifica-se que muitas recomendações ainda não foram adotadas pelas empresas, havendo ainda muito a ser aprimorado em relação ao alinhamento às práticas recomendadas de governança corporativa.

- $\quad$ Em relação ao subíndice de independência apesar de adotar algumas práticas em relação à independência dos conselhos, no geral, todas as empresas da amostra ainda apresentam baixos níveis de independência nos conselhos, pois ficaram (média 1.78) distantes da pontuação máxima para este subíndice (5 pontos). 
- $\quad$ Empresas com negociação de ADR 2 e 3 apresentam valores, em média, superiores de diversidade, possivelmente pelo fato de terem conselhos maiores.

- $\quad$ Níveis inferiores de disponibilidade de tempo nas empresas com negociação de ADR 2 e 3, estas empresas são compostas por conselheiros com maior nível de participação em outros conselhos.

- Os comitês, como órgãos assessores dos conselhos, são peça chave para o funcionamento dos conselhos, no entanto as empresas, em geral, ainda não apresentam sistemas de governança estruturados com Comitê de Auditoria e Remuneração, já que a média geral para esses itens foi de 0.24 e 0.18 , respectivamente.

- Companhias com negociação de ADR 2 e 3 apresentam média significantemente maior em relação a evidenciação, possivelmente por estarem sujeitas à regras mais rígidas em relação à transparência exigidas pela SEC. Todavia, a média geral do índice de evidenciação foi de 1.03 de um total de 6 pontos, evidenciando que há pouca divulgação em relação aos itens analisados (gastos com auditoria; gestão de risco; operações com partes relacionadas; código de ética; remuneração dos administradores). Embora algumas questões já estejam sendo direcionadas pela Instrução CVM no 480/094.

- $\quad$ Empresas com conselheiros ou membros externos com formação em contabilidade na composição do Comitê de Auditoria apresentam média estatisticamente superior comparada às empresas que não têm profissionais com essa formação na composição deste Comitê. Este resultado ratifica o objetivo secundário desta pesquisa de investigar a presença do profissional da área contábil nos conselhos e as associações com o nível de evidenciação das empresas.

- As empresas com maiores índices de alinhamento às práticas de governança apresentam média de nível de evidenciação de 1.03 porém não é estatisticamente superior à média das empresas com menores índices que têm média de 1.01. No entanto, as médias ficaram ainda muito abaixo do máximo esperado nesta pesquisa (6 pontos).

\footnotetext{
${ }^{4}$ Instrução CVM no 480 - Estabelece as regras de registro de emissores de valores mobiliários admitidos à negociação em mercados regulamentados, bem como o regime informacional a que tais emissores estão sujeitos. A Instrução aprofunda o nível de informação em alguns tópicos: transações com partes relacionadas, comentários dos diretores, riscos de mercado, assembleias gerais e administração, e remuneração dos administradores.
} 
As evidências da análise de dados em painel, as quais respondem a questão principal desta pesquisa sobre a relação entre o alinhamento às práticas recomendadas de governança relacionadas ao CA e o nível de evidenciação das empresas, estão descritas na sequência:

- A análise dos resultados da regressão com o método de efeitos aleatórios não apresenta relação positiva entre o alinhamento às práticas de governança e o nível de evidenciação, os resultados se mostram significantes ao nível de 5\%, portanto não há confirmação da hipótese de complementaridade na relação entre evidenciação e adoção de práticas de governança nos conselhos. Todavia, a relação de complementaridade é confirmada entre o nível de evidenciação e as variáveis referentes à negociação no Novo Mercado e empresas com emissão de ADR nível 2 e 3. Este fato poderia sugerir que a adoção de práticas recomendadas de governança nos conselhos destas empresas fortaleceria o papel de monitoramento e controle nas empresas e poderia incentivar a divulgação de informações proporcionando maior nível de evidenciação. Estes resultados são corroborados por outros trabalhos que abordam a relação entre mecanismos de governança isoladamente e o nível de evidenciação: Lanzana (2004) encontrou relação complementar entre a independência do CA e o nível de disclosure; Ho e Wong (2001) apresentam resultados de associação positiva e significante entre a existência de Comitê de Auditoria e o nível de evidenciação; Beekes et al. (2007) encontram que empresas canadenses com melhores estruturas de governança comunicam-se com o mercado por meio de mais documentos.

- $\quad$ Como testes de robustez decidiu-se por analisar as regressões sem as variáveis ADR 2 e 3 e Novo Mercado e o modelo Tobit para minimizar a limitação das variáveis censuradas. Os resultados se mantiveram robustos, no entanto, a significância da variável alinhamento às práticas de governança corporativa não se confirmou ao nível de $5 \%$. O resultado encontrado não sustenta a hipótese de complementaridade de mecanismos. 


\section{CONSIDERAÇÕES FINAIS}

O propósito desta pesquisa foi verificar a relação entre o alinhamento às práticas recomendadas de governança relacionadas ao CA e o nível de evidenciação das empresas. Como objetivo secundário investigou-se a presença do profissional da área contábil nos conselhos e as associações com o nível de evidenciação das empresas.

Com abordagem diferenciada em relação a itens como diversidade dos conselhos e nível de evidenciação de políticas, esta pesquisa procurou contribuir para um panorama das práticas adotadas pelas empresas e para a análise da relação de complementaridade ou substituição das práticas de governança com o nível de evidenciação.

Neste sentido, construiu-se um índice para mensurar o alinhamento às práticas de governança pelo CA. O índice é composto por subíndices referentes à independência, disponibilidade de tempo, diversidade e comitês. Para a variável dependente foi elaborado um índice de evidenciação com base na divulgação de políticas sobre gestão de risco, gastos com auditoria, operações com partes relacionadas, código de ética, remuneração dos administradores. Foram realizadas análises exploratórias com verificação de diferenças entre médias de determinados grupos de empresas e análise de dados em painel para verificar a consistência das relações entre o alinhamento às práticas de governança e o nível de evidenciação.

Os resultados encontrados sobre a extensão da independência, disponibilidade de tempo, diversidade e comitês corroboram evidências de outros estudos conduzidos no Brasil (SAITO; DUTRA, 2002; LANZANA, 2004; MENDES-DA-SILVA et al., 2007; BLACK et al., 2008; CAPITAL ABERTO, 2009; GUERRA, 2009; SANTOS et al., 2009).

Em suma, um panorama das variáveis abordadas reflete que a maioria de independentes nos conselhos é ainda uma recomendação não adotada pelas empresas como recomendado pelo IBGC (2009). A noção de que os conselhos têm grande parte de membros externos é questionável, já que 35.6\% dos conselheiros em 2008 estavam na classificação de

conselheiros afiliados, os quais têm algum vinculo com a companhia ou controlador/majoritário. O principal cargo do conselho, presidente do conselho, é ocupado na grande maioria das empresas $(64.8 \%$ em 2008) também por conselheiros afiliados. Aproximadamente metade dos conselhos pesquisados tem conselheiros com participação em 
mais de 3 conselhos diferentes. Apesar dos conselhos apresentarem diversidade de formação na sua composição, os profissionais da área contábil estavam presentes em apenas $5.2 \%$ dos conselhos em 2008. Há ampla predominância masculina no reduto dos conselhos. Apesar da limitação da coleta de dados referentes à idade dos conselheiros a faixa etária média dos conselheiros é de 51 a 60 anos, apontando a necessidade de maior profundidade de experiência levada ao conselho por conselheiros acima de 50 anos, dos quais espera-se que apresentem maior grau de maturidade.

Os resultados exploratórios apresentados evidenciam que existe diferença entre a média do índice de alinhamento às práticas de governança das empresas com negociação no Novo Mercado e de ADRs 2 e 3 e das empresas que não têm estes tipos de negociação, estas últimas apresentam valores de média inferior para tal índice. Apesar deste resultado já ser esperado, a média do índice de alinhamento às práticas de governança para as empresas da amostra foi de 6.23 de um total de 16 pontos. Assim, constata-se que muitas recomendações em relação à independência, disponibilidade de tempo, diversidade e comitês ainda não foram adotadas pelas empresas, havendo ainda muito a ser aprimorado. $\mathrm{O}$ mesmo resultado ocorreu para o índice de evidenciação, no qual a média da amostra foi de 1.03 de um total de 6 pontos, evidenciando que há pouca divulgação em relação aos itens analisados (gastos com auditoria; gestão de risco; operações com partes relacionadas; código de ética; remuneração dos administradores). Embora algumas questões já estejam sendo direcionadas pela CVM com a Instrução $\mathrm{n}^{\circ} 480 / 09^{5}$.

Com o intuito de explorar as associações entre a presença do profissional da área contábil nos conselhos e o nível de evidenciação das empresas, encontra-se a seguinte evidência: empresas com conselheiros ou membros externos com formação em contabilidade na composição do Comitê de Auditoria apresentam média estatisticamente superior para o índice de evidenciação se comparada às empresas que não têm profissionais com essa formação na composição deste Comitê. Este fato sugere a ideia defendida por Krishnan e Lee (2008) que a presença de especialistas em contabilidade no comitê de auditoria complementa estruturas de governança corporativa forte nas empresas.

\footnotetext{
${ }^{5}$ Instrução CVM no 480 - Estabelece as regras de registro de emissores de valores mobiliários admitidos à negociação em mercados regulamentados, bem como o regime informacional a que tais emissores estão sujeitos. A Instrução aprofunda o nível de informação em alguns tópicos: transações com partes relacionadas, comentários dos diretores, riscos de mercado, assembleias gerais e administração, e remuneração dos administradores.
} 
As evidências da análise de dados em painel não confirmam a hipótese de pesquisa em relação à complementaridade entre a adoção de práticas recomendadas de governança corporativa e o nível de evidenciação. Todavia a relação de complementaridade é confirmada entre o nível de evidenciação e as variáveis referentes à negociação no Novo Mercado e empresas com emissão de ADR nível 2 e 3. Este fato se baseia no racional de fortalecimento do papel de monitoramento e controle nas empresas com negociação no Novo Mercado e na Bolsa de Nova Iorque, as quais estão sujeitas a regras mais rígidas de governança corporativa, fato que poderia incentivar a divulgação de informações proporcionando maior nível de evidenciação.

Este resultado corrobora o encontrado por Lanzana (2004), no âmbito nacional. No entanto, este estudo se limitou a explorar a relação entre apenas dois mecanismos de governança relacionados ao $\mathrm{CA}$, encontrando relação complementar entre a independência do CA e o nível de disclosure. Alguns trabalhos internacionais também englobam a relação entre o nível de evidenciação e os mecanismos de governança isolados: Wright (1996) evidencia que empresas com maior nível de evidenciação são aquelas que possuem menor percentual de membros do conselho associados à família dos gestores ou que mantenham negócios com a companhia; Ho e Wong (2001) apresentam resultados de associação positiva e significante entre a existência de Comitê de Auditoria e o nível de evidenciação e relação negativa entre o nível de evidenciação e o percentual de membros da família no CA; Beekes et al. (2007) encontram que empresas canadenses com melhores estruturas de governança comunicam-se com o mercado por meio de mais documentos. Os resultados encontrados por estes autores estão em linha com os resultados apresentados nesta pesquisa.

Algumas das evidências apontadas nessa pesquisa já estão sob análise da Câmara Consultiva do Novo Mercado (2009) ${ }^{6}$ na revisão dos regulamentos dos níveis especiais de governança corporativa. Algumas recomendações relativas ao CA são: aumento do percentual de conselheiros independentes exigido para o Novo Mercado de $20 \%$ para $30 \%$; aperfeiçoamento da definição de conselheiro independente; vedação à acumulação dos cargos de presidente executivo e presidente do conselho pela mesma pessoa; divulgação sobre a participação dos conselheiros em outros conselhos; constituição de comitês do CA. E em relação à evidenciação, alguns itens já estão sendo abordados pela CVM, tais como, transações com partes relacionadas, riscos de mercado e remuneração dos administradores. Contudo há ainda

\footnotetext{
${ }^{6}$ Responsável pelo processo de revisão do regulamento do mais alto nível de governança corporativa do mercado de ações, bem como dos níveis 1 e 2 .
} 
muito espaço para aprimoramento tanto em relação às práticas de governança quanto em relação ao nível de evidenciação de informações das empresas para o mercado.

Ao observar os resultados desta pesquisa devem-se considerar algumas limitações em relação à dependência direta dos índices elaborados, que estão vinculados à qualidade dos dados disponibilizados pelas empresas. Outra limitação se refere à classificação adotada para os conselheiros independentes, devido à dificuldade de verificar em profundidade os vínculos destes conselheiros com as empresas e seus acionistas nas informações empresariais disponíveis publicamente.

Sugere-se como pesquisas futuras a continuidade da investigação destes parâmetros com amostra abrangendo período maior com o intuito de constatar relações significantes entre as variáveis e com utilização de outros métodos de análise como o GMM. Outra sugestão, explorar a dinâmica interna dos conselhos e seus efeitos na efetividade destes órgãos com proxies que relacionam a diversidade e independência dos conselheiros com o nível de debate e coesão nos conselhos. Por fim, outra abordagem poderia ser realizada ampliando o índice de evidenciação avaliando uma gama maior de informações voluntárias disponibilizadas pelas empresas.

Os avanços das práticas de governança corporativa no Brasil dependem de maior ação dos agentes de mercado, órgãos reguladores e investidores. Os resultados desta pesquisa indicam alguns pontos para melhoria tanto na adoção de práticas de governança quanto no nível de transparência de informações: a composição dos conselhos ainda não tem predominância de conselheiros independentes; há ainda pouca diversidade nos conselhos; é preciso melhorar a evidenciação sobre informações sobre políticas adotadas pelas empresas, principalmente, em relação à remuneração dos administradores e operações com partes relacionadas, pois estas são informações relevantes ao processo de tomada de decisão dos investidores. 


\section{REFERÊNCIAS}

ALMEIDA, José E. F. de. An exploration of boards of directors' quality: the development of an index for directors attributes and the relation with firm value and performance. In: XXXII ENANPAD, Anais... 17., Rio de Janeiro, 2008.

ANDRADE, Maria M. de. Introdução à metodologia do trabalho científico. 6 . ed. São Paulo: Atlas, 2003.

ARFKEN, Deborah; BELLAR, Stephanie; HELMS, Marilyn M. The Ultimate Glass Ceiling Revisited: the presence of women on corporate boards. Journal of Business Ethics, v. 50, p. 177-186, 2004.

BARROS; Lucas A. B. de C (Coordenador). Métodos de investigação empírica com dados observacionais em finanças corporativas. Relatório Técnico para o CNPq, projeto $\mathbf{n}^{\mathbf{o}}$ 401562/2006-9, 2006.

BAYSINGER, Barry D.; HOSKISSON, Robert E. The composition of boards of directors and strategic control: effects on corporate strategy. The Academy of Management Review, v. 15, n. 1, p. 72-87, 1990.

BEEKES, Wendy; BROWN, Philip R. Do better-governed australian firms make more informative disclosures? Journal of Business Finance \& Accounting, v. 33, n. 3-4, p. 422450, 2006. Disponível em: http://ssrn.com/abstract=903453. Acesso em: 11.07.2009.

BEEKES, Wendy; BROWN, Philip R.; CHIN, Germaine. Do better-governed firms make more informative disclosures? Canadian evidence. SSRN, 2007. Disponível em: http://ssrn.com/abstract=881062. Acesso em: 24.07.2009.

BEINER, Stefan; DROBETZ, Wolfgang; SCHMID, Frank; ZIMMERMANN, Heinz. Is board size an independent corporate governance mechanism? International Review for Social Sciences, v. 57, n. 3, p. 327-356, 2004.

BHAGAT, Sanjai; BLACK, Bernard. S. The Non-Correlation Between Board Independence and Long-Term Firm Performance. Journal of Corporation Law, v. 27, p. 231-274, 2001.

BHAGAT, Sanjai; BLACK, Bernard. S. Independent directors. The New Palgrave Dictionary of Economics and the Law, v. 2, p. 283-287, 1998. Disponível em < http://ssrn.com/abstract=1139191> Acesso em: 25.09.2008.

BLACK, Bernard. S.; JANG, Hasung; KIM, Woochan. Does corporate governance predict firms' market values? Evidence from Korea. Journal of Law, Economics and Organization, v. 22, n. 2, p. 366-413, 2006.

BLACK, Bernard S.; CARVALHO, Antonio G.; GORGA, Erica. An Overview of Brazilian Corporate Governance. ECGI Working Paper, Jan.2008. Disponível em: $<$ http://ssrn.com/abstract=1003059>. Acesso em: 8 fev.2008.

BRENNAN, N.; MCCAFFERTY, J. Corporate Governance Practices in Irish Companies. Irish Journal of Management, v. 17, p. 116-135, 1997.

BROOKS, Chris. Introductory Econometrics for Finance. $2^{\text {nd }}$ ed. Cambridge University Press: New York, 2008.

BUSHMAN, Robert; SMITH, Abbie. Financial Accounting Information and Corporate Governance. Journal of Accounting and Economics, v.32, n. 1-3, p. 237-333, 2001.

CADBURY, Adrian. The Financial Aspects of Corporate Governance, Report of the Committee on the Financial Aspects of Corporate Governance. London: Gee \& Co, 1992. 
CÂMARA CONSULTIVA DO NOVO MERCADO. Revisão dos regulamentos de listagem do Novo Mercado, Níveis 1 e 2 de governança corporativa e Bovespa Mais. São Paulo, $2009 . \quad$ Disponível em: $<$ http://www.bmfbovespa.com.br/empresas/download/Recomendacoes_CCNM.pdf>. Acesso em: 03 Fev. 2010

CAPITAL ABERTO. Anuário de governança corporativa das companhias abertas. São Paulo, 2009.

CARTER, Colin B., LORSCH, Jay W. Back to the Drawing Board. Designing Corporate Boards for a Complex World. Massachusetts: Harvard Business School Press, 2004.

CARVALHAL-DA-SILVA, André L.; LEAL, Ricardo P. C. Corporate Governance Index, Firm Valuation and Performance in Brazil. Revista Brasileira de Finanças, v. 3, n. 1, p. 118, 2005.

CATALYST. 2005 Catalyst Census of women board directors of the Fortune 500. New York, 2005.

CLARKE, D. C. Setting the record straight: three concepts of the independent directors. The George Washington University Law School, Working Paper n. 199. 2006. Disponível em < http://ssrn.com/abstract=892037> Acesso em: 11.09.2008.

CLARKE, T. International Corporate Governance: A Comparative Approach. New York: Routledge, 2007.518 p.

CLUBB, Colin. Discussion of 'Do Better-Governed Australian Firms Make More Informative Disclosures?' Journal of Business Finance \& Accounting, v. 33, n. 3-4, p. 451-458, 2006. Disponível em: <http://ssrn.com/abstract=9034536>. Acesso em 02.07.2009.

COLES, Jerilyn W.; MCWILLIAMS, Victoria B.; SEN, Nilanjan. An examination of the relationship of governance mechanisms to performance. Journal of Management, v. 27, n. 1, p. 23-50, 2001.

COMBINED CODE. Financial Reporting Council, 2008. Disponível em: <http://businessschool.exeter.ac.uk/documents/discussion_papers/accounting/2000/0007.pdf >. Acesso em: 24 mar. 2010.

COMISSÃO DE VALORES MOBILIÁRIOS - CVM. Instrução n. ${ }^{\mathbf{4}} \mathbf{4 8 0}$, de 07 de dezembro de 2009. Dispõe sobre o registro de emissores de valores mobiliários admitidos à negociação em mercados regulamentados de valores mobiliários. 2009. Disponível em: < http://www.cvm.gov.br/>. Acesso em: 28 abr. 2010.

DALTON, Dan R.; DAILY, Catherine M.; ELLSTRAND, Allan E.; JOHNSON, Jonathan L. Meta-analytic reviews of board composition leadership structure and financial performance. Strategic Management Journal, v. 19, n. 3, p. 269-290, 1998.

DANTAS, José A.; ZENDERSKY, Humberto C.; SANTOS, Sérgio C. dos; NIYAMA, Jorge K. A dualidade entre os benefícios do disclosure e a relutância das organizações em aumentar o grau de evidenciação. E\&G Economia e Gestão, v. 15, n.11, p.56-76, 2005.

DEFOND, Mark L.; HANN, Rebecca N.; HU Xuesong. Does the market value financial expertise on audit committees of boards of directors? Journal of Accounting research, v. 13, n. 2, p. 153-193, 2005.

DONNELLY, Ray; MULCAHY, Mark. Board structure, ownership, and voluntary disclosure in Ireland. Corporate Governance: An International Review, v. 16, n. 5, p. 416-429, 2008. Disponível em: <http://ssrn.com/abstract=1285250> Acesso em: 13.06.2009. 
DURNEV, Art; KIM, E. Han. To steal or not to steal: firm attributes, legal environment, and valuation. Journal of Finance, v. 60, p. 1461- 1493, 2005.

EISENHARDT, K. M.; KAHWAJY, J. L.; BOURGEOIS III, L. J. Conflict and strategic choice: how top management teams disagree. California Management Review, v. 39, n. 2, p. 42-62, 1997.

ENG, Li L.; MAK, Y. T. Corporate governance and voluntary disclosure. Journal of Accounting and Public Policy, v. 22, n. 4, p. 325-345, 2003.

FICH, Eliezer. M.; SHIVDASANI, Anil. Are Busy Boards Effective Monitors? ECGI Finance Working Paper n. 55/2004. October, 2004. Disponível em: $<$ http://ssrn.com/abstract=677463> Acesso em: 25.09.2008.

FAMA, Eugene; JENSEN, Michael C. Separation of ownership and control. Journal of Law and Economics, v. 26, p. 301-327, 1983.

FELO, Andrew J. Voluntary disclosure transparency, board independence and expertise, and CEO duality. SSRN, 2009. Disponível em: <http://ssrn.com/abstract=1373942>.

FORBES, Daniel P.; MILLIKEN, Frances. Cognition and corporate governance: understanding board of directors as strategic decision-making groups. Academy of Management Review, v. 24, n. 3, p. 489-505, 1999.

FORKER, John J. Corporate governance and disclosure quality. Accounting and Business Research, v. 22, n. 86, p. 111-124, 1992.

GALLON, Alessandra V.; BEUREN, Ilse M.; HEIN, Nelson. Análise da relação entre evidenciação nos relatórios de administração e o nível de governança das empresas na Bovespa. Revista de Informação Contábil, v. 1, n. 2, p. 18-41, 2008.

GILLAN, Stuart L. Recent Developments in Corporate Governance: An Overview. Journal of Corporate Finance, v. 12, n. 3, p. 381-402, 2006.

GREGORY, H. J. International Comparison of Selected Corporate Governance Guidelines and Codes of Best Practice. New York: Weil, Gotshal and Manges, 2007.

GUERRA, Sandra. Os papéis do CA em empresas listadas no Brasil. 216p. Dissertação (Mestrado em Administração) Faculdade de Economia, Administração e Contabilidade FEA, Universidade de São Paulo - USP, São Paulo, 2009.

GUJARATI, Damodar N. Econometria Básica. Tradução da $4^{a}$ edição. Rio de Janeiro: Elsevier, 2006.

HANIFFA, Ros; COOKE, Terry. Culture, Corporate Governance and Disclosure in Malaisian Corporations. Working Paper, University of Exeter, 2000. Disponível em: <http://businessschool.exeter.ac.uk/documents/discussion_papers/accounting/2000/0007.pdf > . Acesso em: 12 fev. 2010.

HE, Luo; LABELLE, Réal; PIOT, Charles; THORNTON, Daniel B. Board monitoring, audit committee effectiveness, and financial reporting quality: review and synthesis of empirical evidence. SSRN. 2008. Disponível em: <http://ssrn.com/abstract=1159453 >. Acesso em: 24.06.2009.

HEALY, Paul M.; PALEPU, Krishna G. Information asymmetry, corporate disclosure, and the capital markets: A review of the empirical disclosure literature. Journal of Accounting and Economics 31, p. 405-440, 2001. 
HEIDRICK \& STRUGGLES. Corporate governance in Europe: what's the outlook? Study, 2005. Disponível em: <http://www.heidrick.com/NR/rdonlyres/B1A816CD-0E51-4605B22C-40CB1B50561D/0/HS_EuropeCorpGovOutlook.pdf> Acesso em: 30.05.2009.

Corporate governance in Europe: raising the bar? Study, 2007.

HERMALIN, Benjamin E.; WEISBACH, Michael S. Boards of directors as an endogenously determined institution: a survey of the economic Literature. National Bureau of Economic Research Working paper 8161, 2001.

HILlMAN, Amy J.; SHROPSHIRE, Christine; CANELLA JUNIOR, Albert A. Organizational predictors of women on corporate boards. Academy of Management Journal, v. 30, n. 4, p. 941-952, 2007.

HILMER, Fred G.; TRICKER, Robert I. An Effective Board.: Corporate Governance for Directors. London: Director Books, 1994.

HO, Simon S. M.; WONG, Kar S. A study of the relationship between corporate governance structures and the extent of voluntary disclosure. Journal of International Accounting, Auditing \& Taxation, v. 10, p. 139-156, 2001.

HUSE, Morten. Accountability and creating accountability: a framework for exploring behavioural perspectives of corporate governance. British Journal of Management, v. 16 special issue n. 1, p. S65-S79, 2005.

INSTITUTO BRASILEIRO DE GOVERNANÇA CORPORATIVA - IBGC. Código de Melhores Práticas de Governança Corporativa, IBGC, 4ª edição, 2009.

INTERNATIONAL FINANCE COPORATION - IFC. Guia Prático de Governança Corporativa: Experiências do círculo de companhias da América Latina. São Paulo: IFC, 2010. Disponível em: <www.ifc.org/corporategovernance>.

JENSEN, Michael C.; MECKLING, William H. Theory of the Firm: Managerial Behavior, Agency Costs, and Capital Structure. Journal of Financial Economics, v. 3, 1976.

JOHN, Kose; SENBET, Lemma W. Corporate governance and board effectiveness. Journal of Banking \& Finance, v. 22, p. 371-403, 1998. Disponível em: $<$ http://ssrn.com/abstract=1297747>. Acesso em: 23.06.2009.

KANG, Helen; CHENG, Mandy M.; GRAY, Sidney J. Corporate governance and board composition: diversity and independence of Australian boards. Corporate Governance: An International Review, v. 15, n. 2, p. 194-207, 2007.

KLAPPER, Leora F.; LOVE, Inessa. Corporate governance, investor protection, and performance in emerging markets. Journal of Corporate Finance, v. 10, n. 5, p. 703-728, 2004.

KLEIN, April. Economic determinants of audit committee independence. The Accounting Review, v. 77, n. 2, p. 435-452, 2002.

KPMG; CEG - Centro de Estudos em Governança Corporativa. A governança corporativa e o mercado de capitais: um panorama atual das corporações brasileiras na Bovespa e nas bolsas norte-americanas. 2008.

A governança corporativa e o mercado de capitais: um panorama das corporações brasileiras na BM\&FBovespa e nas Bolsa norte-americanas. 2009.

KRISHNAN, Jagan; LEE, Jong E. Audit Committee financial expertise, litigation risk and corporate governance. SSRN, 2008. 
LANZANA, Ana Paula. Relação entre disclosure e governança corporativa das empresas brasileiras. Dissertação (Mestrado em Administração de Empresas) Faculdade de Economia, Administração e Contabilidade da Universidade de São Paulo São Paulo. 2004.

LEAL, Ricardo. P.; CARVALHAL-DA-SILVA, André L. Corporate Governance and Value in Brazil (and in Chile). In: LOPEZ-DE-SILANES, Florencio; CHONG, Alberto (ed.) Investor Protection and Corporate Governance - Firm Level Evidence Across Latin America. Palo Alto: Stanford University Press, 2007.

LEVRAU, Abigail; VAN DEN BERGHE, Lutgart A. A. Corporate governance and board effectiveness: beyond formalism. The Icfai Journal of Corporate Governance, v. 6, n. 4, p. 5885, 2007. Disponível em: <http://ssrn.com/abstract=1046981>. Acesso em: 25.06.2009.

MARCONI, Marina de A.; LAKATOS, Eva M. Fundamentos de metodologia científica. 5. ed. São Paulo: Atlas, 2003.

MARTINS, Gilberto de A.; THEÓPHILO, Carlos R. Metodologia da investigação científica para ciências sociais aplicadas. São Paulo: Atlas, 2007.

MENDES-DA-SILVA, Wesley; BRUÉRE, Augusto J.; SANTOS, Joséte F. dos. Aspectos da governança corporativa de empresas listadas na Bovespa: um estudo exploratório sobre a composição e perfil dos conselhos de administração. Revista de Administração e Contabilidade Unisinos. v. 4, n. 2, p. 149-159, 2007.

MENDES-DA-SILVA, Wesley; ROSSONI, Luciano; MARTIN, Diógenes L.; MARTELANC, Roy. A influência das redes de relações corporativas no desempenho das empresas do Novo Mercado da Bovespa. Revista Brasileira de Finanças, v. 6, n. 3, p. 337358, 2008.

MORCK, Randal; SHLEIFER, Andrei; VISHNY, Robert W. Management ownership and market valuation: an empirical analysis. Journal of Financial Economics, v. 20, p. 293-315, 1988.

MUTH, M. M.; DONALDSON, L. Stewardship theory and board structure: a contingency approach. Corporate Governance: An International Review, v. 6, p. 5-27, 1998.

NADLER, David. A; BEHAN, Beverly A.; NADLER, Mark B. Building Better Boards: A Blueprint for Effective Governance. São Francisco: Jossey- Bass, 2006.

NADLER, David A. Building Better Boards. Harvard Business Review, v. 82, n. 5, p. 102$111,2004$.

NICHOLSON, Gavin J.; KIEL, Geoffrey C. C. A framework for diagnosing board effectiveness. Corporate Governance: An International Review, v. 12, n. 4, p. 442-460, 2004. Disponível em: <http://ssrn.com/abstract=608433>. Acesso em: 24.06.2009.

NOE, Thomas; REBELLO, Michael J. The design of corporate boards: Composition, compensation, factions, and turnover. Working paper. Georgia State University, 1996.

ORGANIZAÇÃO PARA A COOPERAÇÃO E O DESENVOLVIMENTO ECONÔMICO OCDE. Os Princípios da OCDE sobre o Governo das Sociedades. 2004. Disponível em: $<$ http://browse.oecdbookshop.org/oecd/pdfs/browseit/260402UE.PDF>. Acesso em: 10.08.2009.

PETTIGREW, Andrew M. On studying Managerial Elites. Strategic Management Journal, v. 13, n. 8, p. 163-182, 1992. 
PETTIGREW, Andrew M.; MCNULTY, Terry. Sources and Uses of Power In and Around the Boardroom. European Journal of Work and Organisational Psychology, v. 7, n. 2, p. 197-214, 1998.

PONTE, Vera M. R.; OLIVEIRA, Marcelle C.; MOURA, Heber; CARMO, Renata C. de A. Análise das práticas de evidenciação de informações obrigatórias, não obrigatórias e avançadas na demonstrações contábeis das sociedades anônimas no Brasil: um estudo comparativo dos exercícios de 2002 e 2005. Revista Contabilidade \& Finanças, edição comemorativa, p. 65-79, 2006.

ROBERTS, John Dominic; MCNULTY, Terry; STILES, Philip, Beyond agency conceptions of the work of the non-executive director: creating accountability in the boardroom. British Journal of Management, v. 16, n. S1, p. S5-S26, 2005. Disponível em: $<$ http://ssrn.com/abstract=681676>. Acesso em: 14.07.2009.

SAITO, Richard; DUTRA, Marcos G. L. Conselhos de Administração: análise de sua composição em um conjunto de companhias abertas brasileiras. Revista de Administração Contemporânea, v. 6, n. 2, p. 09-27, 2002.

SAMPIERI, Roberto H.; COLLADO, Carlos F; LUCIO, Pilas B. Metodologia de pesquisa. 3. ed. São Paulo: McGraw-Hill, 2006.

SANTELLA, Paolo; PAONE, Giulia; DRAGO, Carlo. How independent are independent directors? The case of Italy. SSRN, 2006. Disponível em <http://ssrn.com/abstract=839204> Acesso em: 11.09.2008.

SANTOS, Rafael L.; SILVEIRA, Alexandre Di M.; BARROS, Lucas A. B. de C. Board interlocking in Brazil: director's participation in multiple companies and its effect on firm

value. $\quad$ SSRN, 2009. Disponível em: http://papers.ssrn.com/sol3/papers.cfm?abstract_id=1018796>. Acesso em 07.10.2009.

SILVEIRA, Alexandre Di M. Governança corporativa e estrutura de propriedade. São Paulo: Saint Paul Institute of Finance, 2006.

SILVEIRA, Alexandre Di M; BARROS, Lucas A. B. de C.; FAMÁ, Rubens. Estrutura de governança e desempenho financeiro nas companhias abertas brasileiras: um estudo empírico. Caderno de Pesquisa em Administração, v. 10, n. 1, 2003.

SILVEIRA, Alexandre Di M. da, LEAL, Ricardo P. C.; CARVALHAL-DA-SILVA, André L.; BARROS, Lucas A. B.. Evolution and Determinants of Firm-Level Corporate Governance Quality in Brazil. SSRN Working Paper Series. Jun. 20, 2007. Disponível em SSRN: $<$ http://ssrn.com/abstract=995764>. Acesso em 10 jun. 2008.

SOUZA, Paulo R. E. B. Análise do atual estágio de disclosure das companhias abertas no mercado de capitais brasileiro e contribuições para o seu aprimoramento. 136 p. Dissertação (Mestrado) Faculdade de Economia, Administração e Contabilidade da Universidade de São Paulo - FEA, Universidade de São Paulo, São Paulo, 1996.

SPENCER STUART. Spencer Stuart Board Index, 2009.

STEWART, Thomas A. Intellectual capital: the wealth of new organizations. New York: Broadway Business, 1997.

SUNDARAMURTHY, Chamu; LEWIS, Marianne. Control and collaboration: paradoxes of governance. Academy of management Review, v. 23, n. 3, p. 397-415, 2003.

THE RELATIONSHIP between corporate governance, transparency and financial disclosure. Corporate Governance, v. 10, n. 4, p. 253-255, 2002. 
TIROLE, Jean. The Theory of Corporate Finance. New Jersey: Princeton University Press. 2006.

VALADARES, Silvia M.; LEAL, Ricardo P. C. Ownership and Control Structure of Brazilian Companies. Revista Abante, v. 3, p. 29-56, 2000.

VAN DEN BERGHE, Lutgart A. A.; LEVRAU, Abigail P.D. Evaluating boards of directors: what constitutes a good corporate board? Corporate Governance: An International Review, v. 12, n. 4, p. 461-478, 2004. Disponível em: <http://ssrn.com/abstract=608434>. Acesso em 07.08.2009.

VERRECCHIA, Robert E. Essays on disclosure. Journal of Accounting and Economics, v. 32, p. 97-180, 2001.

WATTS, Ross L.; ZIMMERMAN, Jerold L. Positive Accounting Theory. Englewood Cliffs, New Jersey: Prentice- Hall, 1986.

WOOLDRIDGE, Jeffrey M. Introdução à econometria. São Paulo: Thomson Learning, 2007.

WRIGHT, David W. Evidence on the Relation between Corporate Governance characteristics and the Quality of Financial Reporting. Working paper, University of Michigan Business School, 1996. 